\title{
Imperial Recognition in the Intellectual Sphere: Christians and Philosophers
}

\section{Almost Philosophers: Pagan Philosophers Recognizing Christians}

The earliest Roman sources on Christians are dated to the beginning of the second century. Three famous accounts of Christians are quoted repeatedly: Tacitus, Suetonius, and Pliny the Younger. In their view, Christianity is a criminal superstition. In this chapter, I argue that these authors present only one side of the coin. Epictetus, Marcus Aurelius, Lucian, and Galen provide more positive accounts. Thus, the image of Christians among ancient pagans was not a purely negative one; in a sense, they recognized Christianity as belonging to the category of philosophy.

Tacitus' Annals contain a well-known account of Emperor Nero's persecutions. Tacitus calls Christianity "the deadly superstition," one among "the shocking and shameful things" which flow into the city of Rome. He explains that the Christians were "hated for their crimes" and reports that they were brought to trial for hatred of the human race. Tacitus admits that Nero made the Christians scapegoats in order to deflect the scandalous rumors surrounding him. In the same breath, Tacitus adds that the Christians really "were guilty and deserving of the most unusual exemplary punishments" (Ann. 15.44.2-5).

The claim of Christianity as superstition recurs in Suetonius' book The Lives of the Twelve Caesars. While Suetonius lists Nero's evil deeds, he also mentions the good ones. Among these, he lists the fact that "punishment was inflicted on the Christians, a class of men given to a new and mischievous superstition" (Nero 16.2; trans. Rolfe, LCL). ${ }^{1}$ The third Roman author recurrently quoted is Pliny the Younger. As a propraetor of the province of Bithynia and Pontus, he had to handle legal procedures against local Christians. Pliny seems to be conscious that they are not guilty of grave crimes, and he is somewhat uncomfortable with his task. Pliny, however, sees Christianity as a "corrupt and

1 According to another passage, which is often presented as a reference to Christ (Claudius 5.25), a certain Chrestus has caused disturbances among the Jews, but it is not clear if Chrestus actually means Christ or not (for the differing views, see, e.g., Benko 1980, 1056-1059; Thorsteinsson 2003, 92-96; Cook 2010, 11-28). Whatever the case may be, it does not change the picture of Christians that Suetonius gives in Nero 16. 
immoderate superstition," a kind of disease, which menaces the traditional cults but which can be remedied. He is ready to punish the pure "defiance and inflexible obstinacy" of Christians which he also calls "madness" (amentia) (Ep. 10.96).

John Granger Cook has written an excellent book, Roman Attitudes Towards Christians: From Claudius to Hadrian, where he extensively analyzes these three and some other Roman texts on Christians. In the introduction, Cook suggests that the concept of "othering" is useful for understanding the relationship between the Romans and the Christians. He continues: "There were some Roman intellectuals and officials who viewed ('constructed') the Christians as 'the other'-a novum that they comprehended with difficulty." ${ }^{2}$ Cook formulates this "otherness" of Christianity:

Probably the Roman intellectuals and governors like Tacitus and Pliny were so disgusted at the phenomenon of Christianity that they lacked the inclination to make any profound explorations into the nature of early Christian faith, morality, and ritual practice. What I have sought to do during this project is develop a sympathy for the Romans' shock when they had to deal with this 'other' - these Christians who were so difficult to conceive using the categories they were familiar with. ${ }^{3}$

Cook's view of Christians as "others" is fully justified. Tacitus, Suetonius, and Pliny attest that the Romans had a tendency to count Christianity among the dangerous superstitions. Cook's presentation, however, has a deficiency: it presumes that "otherness" is always coupled with a negative image of the "other." This is not the case. "Otherness" mirrors the identity of the observer; "other" demarcates what the observer is not. For example, Tacitus, Suetonius, and Pliny portrayed Christianity as a superstition—something that they did not think that they themselves held. Yet, although the indications of otherness tend to be negative, they can also be neutral or even laudatory. "Otherness," therefore, is not a purely negative category.

Images of others can contain positive elements, "depending on the relationship between the subject of the image and the examiner's hopes, interests, or fears and what the environmental circumstances, such as the political and economic factors, are at each given time. ${ }^{5}$ The reasons can be even purely

2 Cook 2010, 2; see Barclay 2014, 323-324.

3 Cook 2010, 2.

4 Rauhala 2013, 286.

5 Fält 2008, 41. 
rhetorical. For example, in Romans 1, Paul provides a picture of the pagans as a massa perditionis. In Romans 2, he turns the critical view toward the Jews and blames them, for example, by claiming that some pagans, unconsciously fulfilling the requirements of the Law, are better than Jews transgressing the Law they know (Rom. 2:14-29). ${ }^{6}$ Thus, Paul's view of pagans is turned on its head in consecutive chapters. Early Christian theologians, who usually labeled pagans negatively, could present images of good pagans. ${ }^{7}$

Similarly, pagans did not always present only negative images of Christians. Tacitus, Suetonius, and Pliny provide only a partial sample of the whole. When looking at philosophical accounts, one can find more relaxed attitudes. ${ }^{8}$ While far from promoting Christianity, they can nonetheless see some positive traits in Christians. I will take a look at the Stoic Epictetus, the Emperor Marcus Aurelius, the satirist Lucian, and Galen, the famous physician and philosopher. Their images of Christians contain positive elements. The chief indication is the fact that Christians are assessed in the category of philosophers-albeit with certain limitations.

The first section of this chapter is devoted to Epictetus, who is the earliest and perhaps the most interesting case. I claim that there is still much material left out of the scholarly discussion. The latter section is devoted to Marcus Aurelius, Lucian, and Galen, who were roughly contemporary with each other.

\subsection{Epictetus: Fearless People in Sympathy with Their Words}

The earliest philosopher to speak of Christians is the Stoic Epictetus (ca. 50130). His Discourses and Enchiridion were written just at the beginning of the second century. ${ }^{9}$ It is possible - but far from certain - that Epictetus knew Christians from his childhood in Hierapolis, Asia Minor, where there was a Christian community (according to Colossians 4:13). Born as a slave, Epictetus was sold to Rome, where he had close contacts to the court of Nero in the 6os CE..$^{10}$ We can suppose that he knew about Nero's persecution of Christians (Tacitus, Ann. 15.44; Suetonius, Nero 16.2). ${ }^{11}$ Epictetus studied Stoic philosophy under the Stoic Musonius Rufus, the most distinguished Roman philosopher of his time. After gaining his freedom, Epictetus started his own career as a teacher of philosophy. Possibly in the '8os or 'gos, he resettled in Nicopolis, which

\footnotetext{
6 Räisänen 1987, 97-109.

7 See, e.g., Kahlos 2008 and Tervahauta 2013.

8 See Wilken 1980, 108.

$9 \quad$ For Epictetus' life and works, see Huttunen 20o9, 4-5, and the literature cited there.

10 Millar (1965) has helpfully gathered the evidence of these contacts.

11 This requires the historicity of the persecution recently questioned by Shaw $(2015,2018)$, but whose view has not gained ground (Jones 2017; van der Lans and Bremmer 2017).
} 
today is situated close in Greece to the Albanian border; there he founded a school which became quite famous and attracted students of wealthy families. Nicopolis is also mentioned in the New Testament (Tit 3:12), but it is not certain if there was a Christian community during Epictetus' lifetime. The city was an important harbor on the way to Rome, however, which hardly escaped Christian influence. ${ }^{12}$

Epictetus never unambiguously speaks of Christians, but — as I will showtwo passages actually mention them: Discourses 2.9.19-21 and 4.7.6. In his profound study, Cook addresses the latter briefly, ${ }^{13}$ while the former he does not mention at all. His procedure is indicative of a more general tendency in the scholarship. The scholarly negligence is due to Adolf Bonhöffer's classic Epiktet und das Neue Testament (1911), which deals with parallel texts in depth but delivers only a short discussion on Discourses 4.7.6, while glossing the other passage with superficial references. ${ }^{14}$ Bonhöffer refuted all attempts to find Christian influences in Epictetus' texts. His main goal of attack, however, was Theodor Zahn's inaugural speech as a vice-principal of the University of Erlangen. In this speech, Zahn proposed that Epictetus knew of the New Testament writings and embraced ideas from it, "as long as ... not in contrast to his dogma."15

Zahn emphasized that Epictetus differed from Christians on many points, and "he did not become a Christian, because he was a Stoic and wished to die as a Stoic." He was not even a friend of Christianity or Christians. ${ }^{16}$ Even this moderate statement was too much for Bonhöffer. Zahn claimed that Epictetus' views were not fully coherent, basically due to the inconsistencies in the old Stoic theory but strengthened because of non-Stoic influences. Bonhöffer defended Epictetus' consistency, and in a detailed analysis-partly based on an article by Franz Mörth, who had already criticized Zahn - shot down every sporadic parallel Zahn presented as a proof of Christian influences on Epictetus. A few years after Bonhöffer's Epiktet und das Neue Testament, Douglas S. Sharp published his Epictetus and the New Testament. Sharp concluded that "it is doubtful whether Epictetus was acquainted with the New Testament," the linguistic similarities being mostly due to the fact that both were written in the koine of their time. The case was closed, and Bonhöffer

\footnotetext{
12 For the character of the city, see, e.g., Quinn 1990, 255.

13 Cook 2010, 173.

14 Bonhöffer 1911, 41-44, 72, 273.

15 Zahn 1895, 29; my translation.

16 Zahn 1895, 33-34; my translation.
} 
became the main authority of the consensus since then. Scholars routinely refer to Bonhöffer's classic work on the matter. ${ }^{17}$

A recent example of Bonhöffer's authority is A. A. Long's magnificent monograph on Epictetus. Long's subject is not Epictetus' relationship toward Christians, and it is understandable that he addresses the theme in passing. Long supposes that Epictetus mentions Christians, ${ }^{18}$ but he shares Bonhöffer's view of the very remote relationship between Epictetus' thinking and the New Testament: "Notwithstanding striking verbal parallels, there is no strong reason to think that one has directly influenced the other."19 As we see here, the discussion on Epictetus' view of Christians continues to be steered by Bonhöffer still in the 21st century. Without questioning Bonhöffer's great merits, one should nonetheless be judicious when approaching his work. In a response to Rudolf Bultmann's article which questions Epictetus' Stoic orthodoxy, Bonhöffer claims in an offended tone that his scholarly life's work was dedicated to prove that Epictetus presents "the pure, the genuine and the coherent theory of the old Stoicism." ${ }^{20}$ Here we see his tendency, which is later questioned. Long points out that, despite the fact that Bonhöffer's works are "indispensable for close study of Epictetus' relation to the Stoic tradition ... they tend to overemphasize his doctrinal orthodoxy."21

I claim that Bonhöffer's tendency also affects his assessment of the passages on Christians. It is surprising how briefly he comments on Discourses 2.9.19-21 and 4.7.6. It is especially eye-catching that he does not comment on the word $\pi \dot{\alpha} \theta 0 \varsigma$, which occurs in the former passage with a positive connotation. I will later come back to this term below, but here it is enough to note that the Stoics understood it in the negative sense. Bonhöffer claims that

17 For the significance of Bonhöffer's view in terms of subsequent studies, see Hersbell 1989, 2161. Spanneut $(1962,630-631)$ lists the scholars who have considered it possible that Epictetus did encounter some Christian influence. Recently, Simon Gathercole $(2017,280-282)$ has treated Discourses 4.7.6 in three pages, which is more than usual. He addresses Discourses 2.9.19-21 in a footnote, but notes it as "a fascinating section." Surprisingly, Gathercole does not mention Bonhöffer at all.

18 Long 2002, 17, 110.

19 Long 2002, 35 .

20 "Ich darf wolhl darauf hinweisen, daß meine wissenschaftliche Lebensarbeit hauptsächlich dem Nachweis gewidmet ist, daß wir dem kostbaren Vermächtnis, das uns Arrian von seinem Lehrer hinterlassen hat, im wesentlichen die reine, unverfälschte und konsequente Lehre der alten Stoa, deren ursprüngiche Zeugnisse uns fast ganz verloren gegangen sind, vor uns haben" (Bonhöffer 1912, 282; partial English translation above by me).

21 Long 2002, 36. 
"Epictetus' conception of the essence and the origin of the $\pi \dot{\alpha} \theta \eta$ is completely similar to the old and the genuine Stoicism."22 Surprisingly, he does not discuss Discourses 2.9.20 in his lengthy chapter on the passions. I cannot avoid having the impression that a profound discussion on Epictetus' references to the Christians would have contributed toward ruining the rigid view of Stoic orthodoxy. As this view is relativized today, one can be open to a more relaxed assessment of Epictetus' relationship with early Christianity.

In the following, I first analyze Discourses 4.7.6, as it is a more clear case. Then I proceed to Discourses 2.9.19-21, before concluding with suggestions for further study. In both passages, Epictetus seems to link Christians to Judaism in a way that has continuously confused scholars. A close reading of these two passages shows that against all suspicions they do speak of Christians and that Epictetus knew something about Christians as a distinct group, as well as their teachings. In addition to attesting to the fact that Epictetus spoke of Christians, analysis of these two passages is significant in several ways. First, I will demonstrate that Epictetus borrowed some expressions from Christians. This opens a discussion that Bonhöffer and some others closed a full century ago: because Epictetus cited Christian expressions, there may be more of them in the Discourses. This presents a path for further study. Second, the analysis contributes to our knowledge of early Christianity. Epictetus has been underestimated as a source for early Christianity until now, despite the fact that his texts are contemporary with much of the New Testament and many other of the earliest Christian writings. Third, a close reading of these passages reveals that the Roman attitude toward Christians was not hostile only, but that there was room for more relaxed assessments than what Epictetus' contemporaries Tacitus, Suetonius, and Pliny provided.

\subsubsection{Christians as Fearless Galileans}

In Discourses 4.7, Epictetus speaks of fearlessness and makes a throwaway remark on fearless Galileans. The discourse begins with a description of uncomprehending children and maniacs who do not fear a tyrant, his guards, and their swords. Lack of comprehension or madness explains fearlessness in the face of these threats (section 1-5). Then, Epictetus proceeds with other bases of fearlessness.

22 "Epictets Ansicht über das Wesen und den Ursprung der $\pi \dot{\alpha} \theta \eta$ entspricht vollständig den Anschauungen der Alten, echten Stoa" (Bonhöffer 189o, 278; my English translation). 


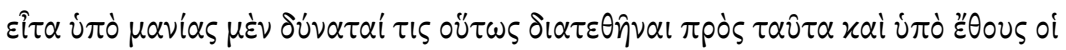

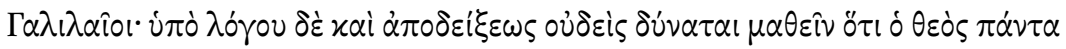

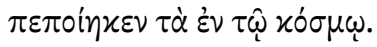

Therefore, if madness can produce this attitude of mind toward the things which have just been mentioned, and also habit, as with the Galilaeans, cannot reason and demonstration teach a man that God has made all things in the universe ...?

Disc. 4.7.6; trans. Oldfather, LCL

The reference to God, who has made all things, begins a long argumentation (sections 6-11) having the aim of proving that one can philosophically justify fearlessness. Epictetus recommends just the philosophical version of fearlessness. Children, maniacs, and Galileans are nothing but the starting point of his argumentation: as they are not afraid of tyrants, guards, and swords, fear or fearlessness cannot be conditioned by these outer circumstances but by the persons themselves. Thus, Epictetus reasons, it is meaningful to seek a philosophical state of mind that enables fearlessness. He mentions Galileans only incidentally, however, without displaying any further interest in them.

At least in the Middle Ages, Galileans were understood as a reference to Christians. A Christian commentator, possibly Arethas of Caesarea (9th-1oth century), noted: "I said above that he seems to have read the Gospels. Now he, however, remembers the Christians themselves though it was not unavoidable. The Lacedaemonians did nothing less." ${ }^{23}$ For the commentator, the reference to Galileans seems to attest to his (or her?) earlier assumption that Epictetus had read the Gospels. The assumption was based on Discourses 3.22.53, which provides a close analogy with Jesus' command to express love toward the enemy. ${ }^{24}$ Though Bonhöffer denied any Christian influence on Epictetus' philosophy, he did not deny that Epictetus knew of the existence of Christians. According to Bonhöffer, Galileans meant Christians, and most scholars have subsequently held that as a self-evident fact. ${ }^{25}$ Eduard Meyer also considered another alternative: Galileans stood for Zealots. Meyer denied this correlation, as one cannot reliably explain why Epictetus would incidentally refer to

\footnotetext{
23 My translation. Schenkl has published all the Greek comments in his edition on Epictetus. On the commentator, see Spanneut 1962, 674-675.

24 The comment is found under Disc. 3.22.58, but it quite certainly addresses the abovementioned section (Oldfather 1928b, 151 n. 2).

25 Bonhöffer 1911, 41-43; Hartmann 1905, 267; Oldfather 1928a, xxvi; 1928b, 363 n. 1; Stellwag 1933, 173; Karpp 1954, 1131; Spanneut 1962, 628; Sevenster 1966, 254-255; Benko 1980, 1077; 1985, 40; Hershbell 1989, 2161; Engberg-Pedersen 2010, 132-133.
} 
a group that was defeated several decades ago in the Jewish war. Thus, Meyer concluded that Galileans must mean Christians. ${ }^{26}$

Martin Hengel, however, became a powerful spokesman of the "Zealot interpretation." He cited the fact that Epictetus lived in Rome during the Jewish war, where he had an opportunity to get to know details of the conflict in Palestine. Hengel also notes that, according to Josephus, the fame of the Jewish resistance movement sicarii-which he lumps together with the Zealots, against his own differentiation between these two-became very famous (Bell. 7.409421, 433-45o). ${ }^{27}$ It is possible that Epictetus knew about the Zealots. Yet, it is very improbable that he would incidentally refer to them. His students would hardly have understood such a reference several decades after the Jewish war. For the same reason, it is also improbable that Epictetus referred to any other Jewish resistance movement during the Jewish war. ${ }^{28}$

Somewhat more probable is a reference to the sicarii who were still active in Egypt and Cyrenaica after the Jewish war, as Josephus has it. In these areas, a Jewish uprising broke out in $115 \mathrm{CE}$, and it may have been contemporary with Epictetus' discourses. ${ }^{29}$ Arrian, who wrote down Epictetus' discourses, was present in Nicopolis in the first or the second decade of the second century. ${ }^{30}$ Thus, in theory, Galileans can mean a group of Jewish rebels who continued the tradition of the sicarii. This is nothing but guesswork, however, as we have no evidence of this kind of group called Galileans. Later, in the 13os, Bar Kokhba spoke of Galileans, but this should apparently be understood as a purely geographical definition of certain people. ${ }^{31}$ Moreover, Arrian, the actual author of the Discourses, was a student prior to Bar Kokhba's uprising.

$26 \quad$ Meyer 1923, 530 n. 1.

27 Hengel 1976, 6o-61. For differentiation between the sicarii and the Zealots, see Hengel 1976, 49. Applebaum $(1971,164)$ had identified Galileans with Zealots before Hengel.

28 Zeitlin (1974) supposes that there was a resistance movement called the Galileans. Feldman (1981) has criticized this suggestion.

29 The uprising broke out also in Crete and Syria. See Hengel 1983. Epictetus possibly refers to this event when he speaks of "the conflict between Jews and Syrians and Egyptians and Romans" (Disc. 1.22.4; trans. Oldfather, LCL). Although there is a question of different views on holiness, it is remarkable that Epictetus mentions the parties of the Jewish uprising.

$30 \quad$ Hartmann 1905, 254; Long 2002, 38. The actual contribution of Epictetus to the Discourses has been widely discussed. Wirth (1967) prefers the view that they are essentially Arrian's production. Some, such as Dobbin (1998, xx-xxiii), prefer the other extreme, claiming that the Discourses were written by Epictetus himself, despite Arrian's claim that he wrote them down. Most scholars, Long (2002, 40-41) among them, trust Arrian's claim. 
Two second-century Christians, Justin Martyr (Dial. 80) and Hegesippus (Eusebius, Hist. Eccl. 4.22.7), mention Galileans as a Jewish sect without any further qualification. It is temporally possible that Epictetus denotes this sect of Galileans. According to the Mishnah, the Galileans criticized the practice of putting the name of the governor with the name of Moses on the bill of divorce ( $m$. Yad. 4:8). This critical attitude toward the authorities fits well with the fearlessness in the face of a tyrant characteristic of the Galileans in Epictetus' reference. Nevertheless, it is improbable that Epictetus meant this Jewish sect. The sect should have been famous enough that Epictetus' incidental reference could have been understandable for his students. This was not the case. The little information we have on the sect proves the opposite. ${ }^{32}$

Epictetus' incidental reference to the Galileans presumes that the group is known to the students without further explications, and Christians are the clearest candidate for this. Though we have no information of a Christian community in Nicopolis during the first decades of the second century, the presence of Christians in the town is more than probable. There were Christians in other Greek cities and in Rome, and Epictetus had connections to Rome and other cities. ${ }^{33}$ It is much more likely that the Galileans are Christians rather than Zealots or members of a Jewish sect called Galileans by Justin, Hegesippus, and the Mishnah. Zealots or sect members would have been too remote from the students to be instantly recognized from Epictetus' incidental reference.

Yet, there is one problem in identifying the Galileans as Christians: the designation "Galileans" itself. The designation unequivocally refers to Christians first in the writings of Emperor Julian in the 4th century. ${ }^{34}$ In the New Testament, the designation refers to a person's birthplace or living place. For example, Peter is identified as a Galilean because of his dialect (Matt. 26:69, 73). Also the designation of the disciples as $\alpha \dot{v \delta} \delta \varepsilon \varepsilon \varsigma \Gamma \alpha \lambda \iota \lambda \alpha i 0$ (Acts 1:11) should be understood as a reference to their birthplace. Philip S. Esler has shed light on the fact that groups that have a designation originating in geography also have a connection to the geographic area. For example, according to Esler, 'Iovঠoîo should be translated as "Judeans," not "Jews." ${ }^{35}$ Geography was also on Julian's mind when

32 Hengel $\left(197^{6}, 5^{8-60}\right)$ claims that the Galileans in the Mishnah refer to the Zealots. If this is so, it does not help to identify the Galileans in Epictetus' text.

33 Hock (1991) has charted Epictetus' network.

34 Hengel 1976, 6o-61. According to a source, the gnostic Valentinus called Christians who believed in Christ's two natures "Galileans." The source is late, however, and it hardly describes Valentinus in a reliable way (Markschies 1992, 270-275).

35 Esler 2003, 40-76. Cohen (1999, 69-101) thinks that "Jews" is an apt translation when the connotation is clearly religious, not national. 
he called Christians "Galileans." Julian's Neoplatonic worldview underlined the local bond of Christianity; it thus denied the universality of Christianity. ${ }^{36}$

For Epictetus, the designation seemingly does not have any ideological significance. Unlike Julian, Epictetus does not particularly resist the group of Galileans, but just uses the designation he knows. The designation surely betrays a connection to Galilee, but it does not imply that every Galilean was born in Galilee. Similarly, "Nazarenes" became a group name which was largely divested of its local overtones. In the Book of Acts, "Nazarenes" means Christians in general (Acts 24:5) and later it is used in reference to a Jewish Christian group. ${ }^{37}$ Furthermore, the designation "Galileans" seems to have turned into a group designation without indicating Galilee as the birthplace of its members. It can be easily understood as a nickname for Christians in general.

The fact that besides Epictetus' text the term "Galileans" is not deployed as a general term for Christians before the 4 th century may justify questioning its originality in Epictetus' text. The text of the Discourses is preserved in a medieval manuscript and later copies. One cannot rule out changes in the manuscript tradition. In theory, it is possible that a Christian copyist has confused another word with the more familiar Galileans. Epictetus speaks of $\Gamma \alpha \dot{\lambda} \lambda$ ol, the priests of Cybele (Disc. 2.20.17), which is the closest to $\Gamma \alpha \lambda \_\lambda \alpha \hat{i} 01$ in

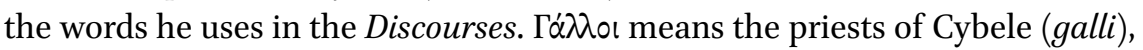

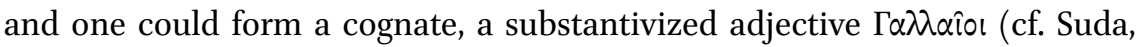
Lexicon $\gamma$ 23). According to Epictetus, $\mu \alpha v^{i} \alpha$ and wine compel the galli to perform what they perform. Epictetus does not qualify the performance, as it is apparently familiar to the audience. ${ }^{38}$ The word $\mu \alpha v^{\prime} \alpha$ is also mentioned in the section on the Galileans, but it does not mean religious ecstasy, as in the case of galli, but pure foolishness. Moreover, Galileans are characterized on the basis of habit, and not by madness. Therefore, it is quite improbable that $\Gamma \alpha \lambda i \lambda \alpha i$ or was originally $\Gamma \dot{\alpha} \lambda \lambda$ o (or $\Gamma \alpha \lambda \lambda \alpha i ̂ \imath)$.

Johannes Schweighäuser proposed that the words of $\Gamma \alpha \lambda$ l $\lambda \alpha \hat{i}$ ol were originally a marginal comment and then copied into the text itself. Schweighäuser based his solution on Paul, who says that Christianity is nothing but foolishness ( $\mu \omega$ pi $\alpha$ ) for the gentiles (1 Cor 1:23). This made Schweighäuser argue that Epictetus cannot see the ground of Christian fearlessness on the basis of habit,

36 Hargis 1999, 117-118; see Gathercole 2017, 281. Quite surprising is Gathercole's (2017, 282) claim that an ethnic designation would prove that Epictetus treats the Christians as anything like a philosophical school. At least there was a philosophical school called Cyrenaics (e.g., Diogenes Laërtius 2.85).

37 For the Nazarenes as a Jewish group, see Luomanen 2005 .

38 See Rauhala (2012) on the image of the Cybele cult. 
but on the basis of foolishness. Since the ground is habit in the text, a reference to the Galileans must be a later emendation. ${ }^{39}$ More recently, Jonathan Barnes has endorsed Schweighäuser's view. ${ }^{40}$ Schweighäuser's argumentation is not very cogent. It strangely attributes authority to Paul to define what all gentiles thought about Christians. In fact, a gentile could see Christians more positively, as is evident in Galen's account from the late second century. He admired the Christian lifestyle and finds fault only in the lack of philosophical argumentation. ${ }^{41} \mathrm{~A}$ gentile did not necessarily see Christians as errant fools.

There is more scholarly discussion on the originality of the word for habit, है $\theta$ os. Many scholars have held it as nothing short of incredible that Epictetus would have seen habit as grounds for Christian fearlessness. Contrary to Schweighäuser, they have usually maintained the term "Galileans" but emended

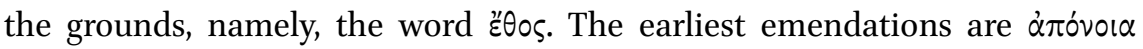

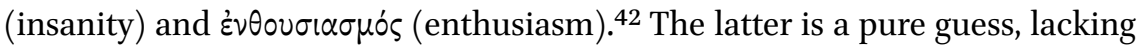
any basis in Epictetus' works. The word does not occur in the extant Discourses or Encheiridion. The former emendation, $\alpha \pi_{0} \operatorname{vol}^{2} \alpha$, is based on the previous section (Disc. 4.7.5), where $\dot{\alpha} \pi \dot{v} v o 1 \alpha$ is used as a parallel for $\mu \alpha v i \alpha$ ( $\dot{\pi} \delta^{\prime} \tau i v o \varsigma \mu \alpha v i \alpha \varsigma$ xai $\alpha$ trovoí $\alpha$ ). There is, however, no similar parallelism in Discourses 4.7.6. The grounds for the Galilean fearlessness is an afterthought too far removed from the word $\mu \alpha v i \alpha$ to create a parallelism. Actually, the syntax requires that the grounds for the Galilean fearlessness differs from that of madness. Repeating the same grounds (i.e., madness) under another word would be unnecessary and confusing. ${ }^{43}$

There are also some other emendations. One scholar proposes the substantive $\pi \varepsilon \boxminus \theta \dot{\omega}$ (conviction) instead of "ैं $\theta$, because Lucian says that Christians, being convinced ( $\pi \varepsilon \pi \varepsilon^{i}(x \alpha \sigma l)$ of immortality, despise death (Lucian, Peregr. 13) ${ }^{44}$ Another scholar responds that the neutral conviction-that is, besides madness - is as unsatisfactory as habit. Resting on what Pliny the Younger (Ep. 10.96) and Marcus Aurelius (Med. 11.3) say about Christians, this second scholar finds $\dot{\alpha} \pi \varepsilon \dot{\varepsilon} \theta \varepsilon$ l (obstinacy) to be an apt emendation. ${ }^{45}$ A third scholar develops these two considerations. He remarks that Epictetus has a techni-

\footnotetext{
39 Schweighäuser 1799c, 913-915.

$40 \quad$ Barnes 1997, 63 n. 157.

41 See my discussion on Galen in this chapter.

42 See the textual apparatus in Schenkl's edition.

43 The parallelism would require that $\alpha$ róvol $\alpha$ is closely connected with $\mu \alpha v^{\prime} \alpha$. Had Epictetus said that the Galilean fearlessness is based on madness, the end of the clause might go:

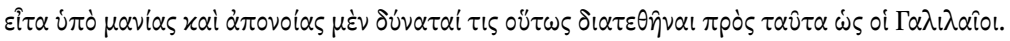

44 Meiser 1910.

45 Corssen 1910.
} 
cal word for irrational conviction $(\pi \dot{\alpha} \theta \circ \varsigma)$ and emends the text with it. He argues further that Epictetus characterizes Christians with the same word in Discourses 2.9.20.46 All these emendations of है $\theta$ os are highly hypothetical and unnecessary. The text is understandable in its textual context and does not appreciate Christians in a way that would make questionable a non-Christian authorship. ${ }^{47}$ Syntactically $(\mu \dot{\varepsilon} v-\delta \dot{\varepsilon})$ Christians are on the side of the maniacs against those whose fearlessness is based on reason and demonstration. Thus, Christians are as unphilosophical as maniacs. But this does not mean that Christians are maniacs. Actually, Christian fearlessness is not based on madness but on habit. ${ }^{48}$

What, then, is this habit? According to Troels Engberg-Pedersen, Epictetus perhaps "means that the Christians were brought up more or less blindly, that is, without 'reason and demonstration', to have their strange beliefs." 49 As we saw, the syntax betrays that Christians are without "reason and demonstration." Their beliefs were surely strange to Epictetus. Yet, we can be more precise, since ${ }^{\varepsilon} \theta 0 \varsigma$ ('habit') and its cognate $\dot{\varepsilon} \theta i \zeta \omega$ are technical terms in his philosophy. ${ }^{50}$ According to Epictetus, habit has no unequivocal relationship with rationality or irrationality. It means just the thinking and acting we are habituated to. In other words, the "normal" decisions and value judgements we make without

46 Kronenberg 1910. As we will see below, Epictetus speaks of Christians in Disc. 2.9.20, but this is not as self-evident as Kronenberg suggests.

47 See the account on Christ in Josephus' Antiquitates judaicae. The account is surely a Christian addition or-if Josephus himself wrote something on Jesus-fully rewritten by a Christian. The tone is unmistakably that of a Christian: "About this time there lived Jesus, a wise man, if indeed one ought to call him a man. For he was one who wrought surprising feats and was a teacher of such people as accept the truth gladly. He won over many Jews and many of the Greeks. He was the Messiah. When Pilate, upon hearing him accused by men of the highest standing amongst us, had condemned him to be crucified, those who had in the first come to love him did not give up their affection for him. On the third day he appeared to them restored to life, for the prophets of God had prophesied these and countless other marvelous things about him. And the tribe of the Christians, so called after him, has still to this day not disappeared" (Josephus, Ant. 18.63-64; trans. Feldman, LCL.). Ulrich Victor (2010) defends the authenticity of this passage. While he argues with certain success that the words "if indeed one ought to call him a man" is a fixed topos in antiquity and that "the Messiah" should be understood as the proper name "Christ," he does not explain how a Jew would admit that prophets were speaking of Christ. This idea sounds too Christian to be from Josephus' pen.

48 Similarly Ramelli 2015, 127.

49 Engberg-Pedersen 2010, 133.

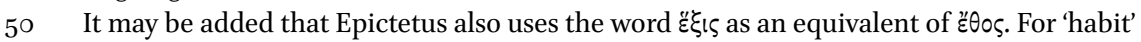
in Epictetus, see Hijmans 1959, 64-65 and Huttunen 2009, 127-128. Gathercole (2017, 282) also notes the technical role of habit in philosophy, but for some reason or other he does not refer to its use in Epictetus' works. 
elaborated consideration are based on habit. Everyone has habits developed since childhood. Even those who have learned the philosophical truths can act against such truths on the basis of habit: "In the course of years we have acquired the habit $\left(\varepsilon^{i} \theta i \sigma \mu \varepsilon \theta \alpha\right)$ of doing the opposite of what we learn and have in use opinions which are the opposite of the correct ones" (Disc. 2.9.14; trans. Oldfather, LCL; cf. 3.19.4-6). Thus, the roots of habits are strong. The uprooting and the changing of bad habits require hard practical training ( $\left.\alpha_{\sigma \alpha} \sigma \eta \sigma \varsigma\right)$ after one has learned theoretical truths $(\mu \dot{\alpha} \theta \eta \sigma \iota \varsigma)$ and meditated on the practical application of those truths ( $\mu \varepsilon \lambda \varepsilon \dot{\tau} \eta)$ (cf. Disc. 2.9.13)..$^{51}$ The antidote to bad habits is the opposite habit:

(4) What reinforcements, then, is it possible to find with which to oppose habit ( $\left.\varepsilon^{\prime} \theta \circ\right)$ ? Why, the contrary habit ( $\left.\varepsilon^{\prime} \theta \circ \varsigma\right)$. (5) You hear the common folk saying, "That poor man! He is dead; his father perished, and his mother; he was cut off, yes, and before his time, and in a foreign land." (6) Listen to the arguments on the other side, tear yourself away from

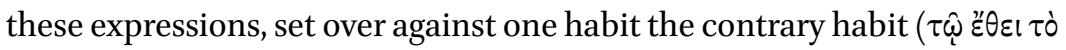

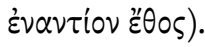

Disc. 1.27.4-6; trans. Oldfather, LCL

Epictetus' text presents nicely how one has to be habituated into a philosophical value judgment of death. Of practical help are short sentences, or "canons"

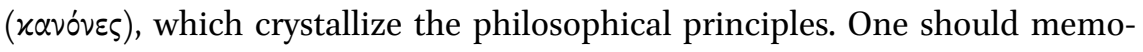
rize these in order to have them at hand in practical situations. Epictetus gives an example of two canons that are useful "when death appears to be an evil": "It is a duty to avoid evils" and "Death is an inevitable thing" (Disc. 1.27.7; trans. W. A. Oldfather, LCL, revised). ${ }^{52}$

When Epictetus speaks about the habit of the Galileans, he presupposes that Christians are brought up to be fearless, either from childhood or after their conversion. He also possibly knows that Christians had canons of their own. ${ }^{53}$ For example, Paul presents the sentence "Neither circumcision nor uncircumcision is anything; but a new creation is everything!" as a canon (Gal. 6:15-16; cf. 1 Cor. 7:19.). Thus, Paul's canon has nothing to do with fearlessness, but 4 Maccabees does speak of such a canon: vicious emotions $(\pi \dot{\theta} \theta \eta)$ are

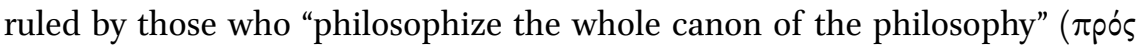

$5^{1} \quad$ For the threefold division, see Bonhöffer 189o, 10; 1894, 147; 1911, 14; Hijmans 1959, 64-68; Barnes 1997, 47-48.

$5^{2}$ For the canons in Epictetus, see Newman 1989, 1496-1502.

53 For the use of the word $x \alpha v \dot{\omega} v$ in Christian writings, see, e.g., Beyer 1974. 


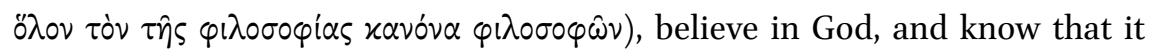
is blessed by virtue of enduring all pain (4 Macc 7:21-22; my trans.). Though 4 Maccabees clearly embraces Stoic ideas, ${ }^{54}$ Adolf Bonhöffer aptly notes that $\alpha v \omega^{\prime} v$ is not at all a distinctively Stoic technical term. He concludes that the use of the word in Paul or in 4 Maccabees does not attest to any particular connection between those texts and Epictetus. ${ }^{55}$

However, Paul makes clear that Christians also used short sentences as canons. These canons surely were-as Engberg-Pedersen puts it—-strange beliefs" for Epictetus, something which could be lumped together with madness, but only when compared with "reason and demonstration." At the same time, Engberg-Pedersen acknowledges that these "strange beliefs" were not an equivalent to madness in every respect. Christians were so well trained in their beliefs that they were actually fearless in front of threats. In Epictetus' ranking, Christian fearlessness is an admirable result, albeit on the wrong grounds. While this conclusion does not presume that Epictetus' knowledge of Christians or Christianity was deep, he still seems to know more than he says, expecting the same knowledge of his audience. Otherwise a passing reference could not be understandable.

Epictetus' words do not reflect Tacitus', Suetonius' or Pliny's prejudices against Christian beliefs as a superstition. Although Epictetus lumps Christianity together with madness, this is not a polemical claim. He merely points out that Christians are not real philosophers. Their fearlessness is not based on madness but on habituation without apt philosophical grounds. Actually, he thinks that Christians are as fearless as philosophers should be.

\subsubsection{Christians as Real Jews Practice What They Preach}

What Epictetus says of Galileans in Discourses 4.7.6 shows that he knew Christians as a group of its own. In Discourses 2.9.19-21, he compares Stoics to Jews. This connection is not without parallels. For example, Josephus compared the Pharisees to the Stoics (Vita 12). Epictetus' passage, however, contains some features that may make the reader ask if Epictetus in fact is speaking about Christians. I am not claiming that Epictetus mistook Christians as Jews. As I said, Discourses 4.7.6 shows that Epictetus identified Christians as comprising a group of their own. On the other hand, Epictetus knew Jews

54 According to Renehan (1972) and Klostergaard Petersen (2017a, 148), 4 Macc is usually seen as vacillating between Stoicism and Platonism. Renehan supposes that this is due to the influence of Middle Stoicism. Renehan's highly erudite article shows verbal similarities with texts which seem to originate with the Middle Stoic philosopher Posidonius. Posidonius adapted certain Platonic components into his philosophy.

Bonhöffer 1911, 119-120. 
as a people parallel to Syrians and Egyptians (Disc. 1.22.4). Thus, instead of claiming that 'Jews' in Epictetus' parlance simply means Christians, I suggest a more nuanced relationship between Jews and Christians in his understanding. Epictetus makes a distinction between the Jews and the real Jews. I claim that the latter group actually denotes Christians. The distinction is anti-Jewish and, thus, it seemingly originates from Christians who claimed to be the real heirs of God's promises. In other words, Discourses 2.9.19-21 reflects Christian suprasessionist theology. This is an unexpected detail in a philosophical text of the early second century. On the other hand, Epictetus himself does not have any deeper interest in the Jewish-Christian relationship. The issue illustrates in passing his main point regarding philosophical lifestyle. In the Discourses, Epictetus includes details from every branch of life in order to illustrate his philosophical teachings. Christians are just one illustrative analogy among many others. However, it is interesting that Christians are mentioned at all. Moreover, it is important to note that Epictetus had such a close knowledge of the Jewish-Christian debate.

The complexities of Discourses 2.9.19-21 require a careful and close reading in three stages. First, I prove that scholars have seriously misunderstood the passage because of an unnecessary emendation of the text in the standard editions. I read the original text of the passage and present its message as a part of Epictetus teaching. This prepares one to observe details in the second stage, where I show that Epictetus uses several loan expressions. Above I mentioned that $\pi \dot{\alpha} \theta 0 \varsigma$ unexpectedly occurs with a positive meaning. There are also other expressions that strikingly differ from Epictetus' normal parlance. The deviant features indicate loans. The third stage is to specify the origin of these loans. I give proofs that the loans most probably go back to Christian usage. The most indicative is the understanding of baptism as a non-recurrent rite. Jewish ablutions were typically recurrent. The Jewish baptism of proselytes was nonrecurrent, but it does not fit with the original text of the passage. While the emended text speaks of a non-Jew becoming a Jew, the original text speaks of a Jew becoming a real Jew. In the original text, Christian baptism seems to be the only explanation for a baptism occurring only one time. In addition to the fact that the Christian practice of baptism suits Epictetus' text, the closest analogies also lie in Christian texts. Now it is time to enter the first stage of my analysis.

\subsubsection{The Passage and Its Message}

The passage I am analyzing is an integral part of Discourses 2.9, headed "That although we are unable to fulfil the profession of a man, we adopt that of a philosopher" (trans. Oldfather, LCL). Epictetus claims that each profession $(\varepsilon \pi \alpha \gamma \varepsilon \lambda i \alpha)$-for example, that of a carpenter or grammarian-requires 
conduct corresponding to the profession. The corresponding conduct preserves $\left(\sigma \omega^{\prime} \zeta \omega\right)$ the profession while deviant conduct destroys ( $\left.\dot{\alpha} \pi \circ \lambda \lambda \dot{\nu} \mu l\right)$ it. After this general introduction, Epictetus turns to the profession of a philosopher. A Stoic philosopher should live like a philosopher, in harmony with the philosophical doctrines. As indicated above, it is not enough to learn philosophical truths, but it is also necessary to meditate on them and practically train in them as an antidote to bad habits (Disc. 2.9.13-14). Mere technical discussion of philosophical doctrines does not make anyone a philosopher. ${ }^{56}$ In this context follows the passage I am going to analyze.

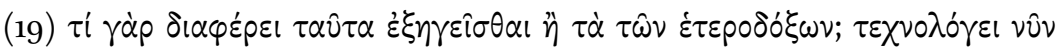

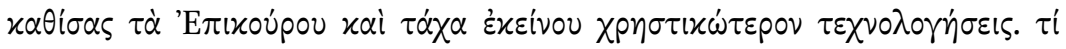

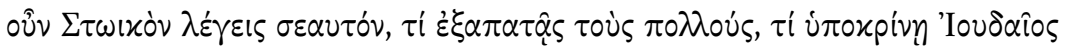

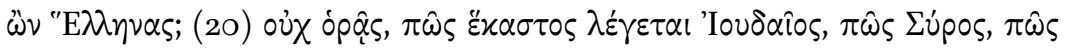

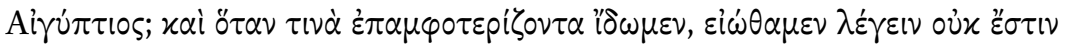

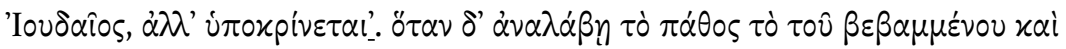

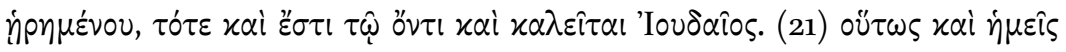

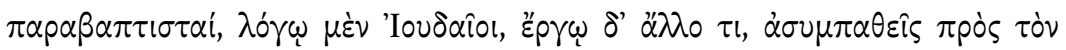

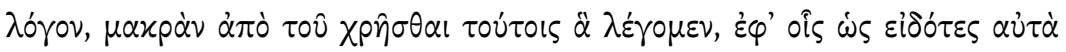
$\dot{\varepsilon} \pi \alpha i \rho o ́ \mu \varepsilon \theta \alpha$.

(19) For how much better is it to set forth these principles than those of the other schools of thought? Sit down now and give a philosophical discourse upon the principles of Epicurus, and perhaps you will discourse more effectively than Epicurus himself. Why, then, do you call yourself a Stoic, why do you deceive the multitude, why do you being a Jew act the parts of Greeks? (20) Do you not see in what sense men are severally called Jew, Syrian, or Egyptian? For example, whenever we see a man halting between two faiths, we are in the habit of saying, "He is not a Jew, he is only acting the part." But when he adopts the pathos ${ }^{57}$ of the one who has been baptized and has made his choice, then he both is a Jew in fact and is also called one. (21) So we are also counterfeit "baptists," Jews in words, but in deeds something else, not in sympathy with our own words, ${ }^{58}$ far from applying the principles which we profess, yet priding ourselves upon them as being men who know them.

Disc. 2.9.19-21; trans. Oldfather, LCL, revised

$5^{6}$ See also Bonhöffer 189o, 11-13; Long 2002, 107-112.

57 The word is not translated here. Possible translations are discussed below.

$5^{8}$ An alternative translation for 'words' is 'reason,' but the context here prefers the former. 
Epictetus' basic message in this passage seems to be clear: one's words and deeds should correspond. However, the abrupt change of the grammatical person is somewhat confusing. In section 19, Epictetus blames 'you' (singular) for non-corresponding words and deeds. In section 21, all those present ('we') are blamed for the same vice. 'You' is best understood as a rhetorical appeal to each of Epictetus' listeners and, thus, he addresses no individual. Actually, 'you' refers all those present, including Epictetus. ${ }^{59}$ In section 20, the grammatical person varies. In the beginning, Epictetus uses 'you,' then moves to the passive voice to illustrate what people generally say, and then exemplifies the general attitude by referring to 'us.' Thus, there is a transition from 'you' to 'we' in section 2o. However, Epictetus is all the while addressing the same people, his audience. Another, more confusing feature in the passage is the metaphorical use of the designation "Jews." Does Epictetus assume that the audience consists of Jews who are acting the parts of Greeks (section 19)? Or are they non-Jews acting the part of Jews (section 20)? Or are they something in between, Jews in word and non-Jews in deed (section 21)? The most serious problem concerns sections 19 and 20 : is the basic identity that of a Jew (section 19) or that of a non-Jew (section 20)? Section 21 can be harmonized with either, though in this section Epictetus clearly prefers being a wholehearted Jew.

The tension between sections 19 and 20 has traditionally been resolved by means of an emendation. Heinrich Schenkl embraced this solution in his critical editions of Epictetus' Discourses (1894 and 1916 repr. 1965). ${ }^{60}$ He makes a text-critical conjecture in the end of section 19. Instead of the reading that 'you'

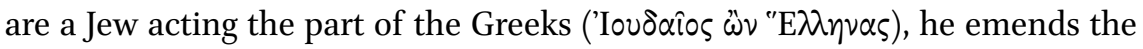

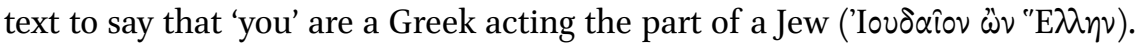
This emendation was then accepted by W. A. Oldfather in his edition published in the Loeb Classical Library series (1925-1928; several reprints) and by Joseph Souilhé in his Budé edition (1948-1965). Schenkl's, Oldfather's, and Souilhé's emended editions are standard reference books, which practically all scholars use without further text-critical discussion. The emendation creates the impression that Epictetus is speaking of Greeks who partly embrace Judaism (sections 19-20), but who should embrace it wholeheartedly in order to become real Jews (section 21). It is no wonder that in scholarly literature this passage is usually presented as a reference to pagan sympathizers of Judaism (sections 19-20), who are assumed to have become proselytes (section 21).

59 The rhetorical change of the grammatical person is very common in Epictetus. A good example is Disc. 2.17.13-18, where Epictetus changes the grammatical person from 'we' to 'you' (singular) and finally to 'I', as a rhetorical device. See Huttunen 2009, 101-102. 
For example, John G. Gager writes: "The context indicates clearly that he is speaking of converts to Judaism." ${ }^{\prime 1}$ This assumption, however, is based on the emended text.

The emendation can be supported by one testimony, John Upton's commentary on Epictetus published sometime between the years 1739 and 1741. Upton cites the first printed version of Discourses from 1535, which is not preserved. ${ }^{62}$ Upton reads 'you' as a Greek acting the part of the Jews ('Iovס $\alpha$ ious $\omega \nu$ "E $\lambda \eta \nu \nu$ ). The difference between Upton and the modern editions is minor: modern editions read Jew in the singular, while Upton provides a plural form. This does not affect the basic logic. However, Upton is quite vague as to any external evidence. The modern editors do not fully trust Upton, as attested by the change from the plural to the singular. Upton is also quite late compared to the oldest remaining manuscript. That manuscript originates from the Middle Ages, probably from the 11th or 12th century, and there are several copies of it without changes in this reading. ${ }^{63}$ What comes to the internal evidence, one must admit that the manuscript reading is logically difficult. Upton's reading and the modern editions obviously improve the logic in the passage. Yet, the manuscript reading is not so completely nonsensical that one must reject it. Next, I will show how the manuscript reading makes sense.

Section 19 presumes that the difference between a Greek and a Jew has something to say about the difference between a Stoic who just speaks of philosophical principles and the Stoic who also follows those principles in their life. Section 21 assumes that one should live in accordance with Jewish principles. The wholehearted Jewish lifestyle is a metaphor for the ideal Stoic lifestyle, and the Jew is a metaphor for the Stoic. In his rhetoric, Epictetus assumes that his audience consists of Stoics who-alas! — do not practice what they preach. As the audience is put in the place of Jews (that is, Stoics), the basic identity constructed in the passage is that of a Jew. This is his definition, while in section 20 he describes the understanding of "the multitudes" (oi $\pi \circ \lambda \lambda_{0} i$ ); the word for the common people is clearly degrading, and it refers to their lack of instruction. ${ }^{64}$ They simply define a person's identity by his or her conduct.

\footnotetext{
$61 \quad$ Gager 1983, 77 .

62 On this printed version, see Sicherl 1993.

63 The basic facts on the manuscripts and sources are found in the modern editions. See also Dobbin 1998, xxiii-xxiv.

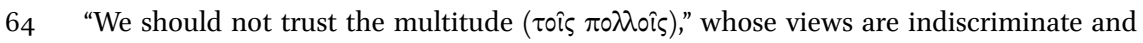
unphilosophical, Epictetus says (Disc. 2.1.22; trans. Oldfather, LCL). On this saying, see Huttunen 2009, 106-107. Here Epictetus is in the line of the early Stoic Cleanthes, who advised not to fear the indiscriminate utterances of the multitude $(\pi \circ \lambda \hat{\omega} v)$ (Stoicorum veterum fragmenta 1.559).
} 
This simple definition is no mistake as such. Epictetus continues that this is the way 'we,' the educated, also define identity. The general criteria for defining people's identity are given in the passive voice ( $\lambda \dot{\varepsilon} \gamma \varepsilon \tau \alpha l, \kappa \alpha \lambda \varepsilon i \tau \alpha l)$. The problem is the contradiction between words and deeds, which is a central theme in Epictetus' Discourses. ${ }^{65}$ The multitudes, however, do not realize this complex identity. For them, the basic Jewish identity remains secret because of the deficiency in Jewish conduct. In the case of the tension between Jewish words and non-Jewish deeds, they base their understanding on deeds and, consequently, define the basic identity as a non-Jewish one. In section 21, Epictetus admits that the simple definition of the multitudes is in some sense right. Jews are really Jews only when their words and deeds are concomitantly Jewish. In reality, Epictetus sees the identity of his audience as being more complex. Their basic identity is that of Jews, though their conduct is deficient and deceives the multitudes to form a problematic conclusion.

What makes the logic of the passage difficult is the twofold use of the word i $\pi$ oxpivoual ('act a part'). For a scholar of the New Testament, it may sound negative that something is labeled as hypocrisy. For Epictetus, however, the word is quite neutral. It hints at the idea that the world is like a theater. This idea is well known in antiquity, and Epictetus also embraces it (Disc. 1.29.41-47; fr. 11; Ench. 17). ${ }^{66} \mathrm{He}$ understood God as the director of this divine play, assigning to

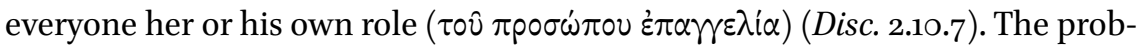
lem is not that people act their parts, but that they act the wrong parts, which God has not assigned to them. In section 19, the problem is that this 'you' acts the parts of Greeks instead of the right part of a Jew. In section 20, Epictetus presents how people generally define the identities of a Jew and a non-Jew. He speaks of the conclusion that anyone, even Epictetus himself and his audience, are wont $(\varepsilon i \dot{\omega} \theta \alpha \mu \varepsilon v)^{67}$ to make if the identity is based on the non-Jewish con-

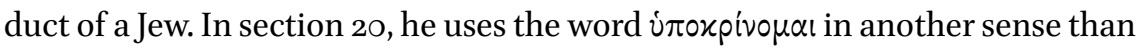
in section 19. Here he deviates from its philosophical usage, moving instead to the vernacular. In the vernacular usage, it means something detached, superficial, and spurious, acting in contrast to a genuine lifestyle. Thus, there is close similarity with the idea of hypocrisy in the New Testament (e.g., Gal. 2:13-14). ${ }^{68}$

The passage and its message are understandable without emendations. The key to following the manuscript reading is to recognize that in section 20 ,

65 See, e.g., Huttunen 2009, 101-112.

66 For the idea of the world as a theater in Epictetus, see, e.g., Gretenkord 1981, 227-230, and Huttunen 2009, 45 .

67 According to Nolland $(1981,181)$, the word $\varepsilon i \omega \theta \theta \mu \varepsilon v$ proves that the following saying is an established proverb.

68 See Wilckens, Kehl, and Hoheisel 1988, 1209. 
Epictetus embraces a more general level in common with the multitudes. He does this in order to point out that not even the common people-however indiscriminate and foolish their views are otherwise-identify the audience as Jews (that is, Stoics) as long as deeds do not follow words. Epictetus basically agrees that one should practice what one preaches. Still, the actual identity of the audience is more complex, basically being Jewish but remaining incomplete and unrecognizable until they practice what they preach. The incomplete Jewish identity is a metaphor for the present and incomplete Stoic identity of the audience. In the following, I am interested in what information the metaphor provides about the Jews. The emended text promotes the common scholarly view that Epictetus is speaking about sympathizers of Judaism who should become proselytes. The manuscript reading does not lend support to such view. As Epictetus is speaking of Jews from the outset (instead of a Greek acting the part of a Jew), he is not speaking of sympathizers or wannabe Jews. He speaks of two kinds of Jews: those who do not practice what they preach and those who do. The manuscript provides a situation where Jews not following their faith are supposed to make a change in their conduct after baptism and make a choice-although Epictetus does not say what this choice involves. As I will demonstrate, this lack of clarity is one indication of loan expressions.

\subsubsection{Loan Expressions}

The reference to baptism has made some scholars-for example, Oldfather in his edition-suppose that Epictetus is actually speaking of Christians. Other features raise similar thoughts. Before prematurely hastening to such conclusions, however, it is necessary to read the text carefully. I claim that several expressions are loans in Epictetus' usage and that they have a Christian origin.

As I briefly noted above, the word $\pi \dot{\alpha} \theta 0 \varsigma$ instantly catches the eye of one who is familiar with Epictetus' philosophy or Stoic philosophy in general. Besides this passage, Epictetus uses the word ten times. ${ }^{69}$ In all of these ten occurrences, $\pi \dot{\alpha} \theta 0 \zeta$ is something negative, in accordance with the Stoic philosophy in general. ${ }^{70}$ Epictetus tells us that $\pi \dot{\alpha} \theta 0 \varsigma$ is the emotion that arises when people do not get what they like or when they receive something that they actively dislike. Symptoms of this $\pi \dot{\alpha} \theta$ os include, for example, sorrow, lamentation, and envy (Disc. 3.2.3; cf. 1.27.9-10); it is said to be like a disease or scar

69 Disc. 1.4.26; 1.27.10; 2.18.11; 3.1.8; 3.2.3 (two times); 4.1.57, 115; 4.8.28; fr. 20.

70 For the Stoic definition of $\pi \dot{\alpha} \theta 0 \varsigma$, see, e.g., Forschner 1995, 114-123, and Brennan 1999, 21-39. Bonhöffer (189o, 276-28o) has analyzed Epictetus' use of the Stoic philosophy visà-vis $\pi \dot{\alpha} \theta 0 \varsigma$ rather than the use of the word itself. 
which requires careful treatment (Disc. 2.18.10-11; 4.8.27-29). Epictetus states that a person without $\pi \dot{\alpha} \theta 0 \varsigma$ is morally good: she or he praises just people (Disc. 3.1.8). It goes without saying what kinds of people praise a person with $\pi \dot{\alpha} \theta 0 \varsigma-$ namely, $\pi \dot{\alpha} \theta 0 \varsigma$ and vices are two sides of the same coin. Keeping this general background in mind, it is baffling that Epictetus makes a moral example of a Jew with $\pi \dot{\alpha} \theta 0 \varsigma$. Readers seem to have intuitively seen that the standard Stoic or Epictetan understanding of $\pi \dot{\alpha} \theta$ os does not fit here. There is a wide range of translations, but they usually refer to a mental disposition or conduct, or some kind of persecution. ${ }^{71}$

Theoretically speaking, $\pi \dot{\alpha} \theta 0 \varsigma$ might be taken within the context of its ordinary Stoic meaning here. A Jew with $\pi \dot{\alpha} \theta$ os would be just an example of a wholehearted life: just as $\pi \dot{\alpha} \theta 0 \varsigma$ makes a real Jew, some more positive feature similarly makes a real Stoic. This would require that Epictetus has a negative picture of the Jews, which is improbable. Elsewhere he mentions the Jews when discussing disputes about dietary laws. Epictetus claims that one can find clarity for the problem with the help of philosophy (Disc. 1.11.12-15; 1.22.4). In these passages, Epictetus clearly thinks that Judaism has its own philosophical deficiencies. However, he also saw deficiencies in other peoples. Hence, nothing indicates that Epictetus would have labeled one of those peoples with the word $\pi \dot{\alpha} \theta 0{ }^{72}{ }^{72}$ It is therefore better to hold to the intuitive impression that the Jewish $\pi \dot{\alpha} \theta \circ$ s indicates something positive. This means that the meaning of the word $\pi \dot{\alpha} \theta 0 \varsigma$ in Discourses 2.9.20 radically deviates from its usual meaning in the Epictetan texts.

The word $\pi \dot{\alpha} \theta 0 \varsigma$, derived from the same root as the verb $\pi \dot{\alpha} \sigma \chi \omega$ ("to suffer"), has the added nuance of being a passive object. The context, however, assumes that $\pi \dot{\alpha} \theta 0 \varsigma$ unfolds itself in daily activity. This communicates Epictetus' basic point of the passage: to not only speak but also practice the philosophical truths. A Jew with $\pi \dot{\alpha} \theta 0 \varsigma$ exemplifies that. As $\pi \dot{\alpha} \theta 0 \varsigma$ is somehow related to conduct, the passively labeled $\pi \dot{\alpha} \theta 0 \varsigma$ is quite unexpected. Instead of $\pi \dot{\alpha} \theta 0 \varsigma$, the reader would

71 Translation terms indicating a mental disposition: adfectus, animi sensus (Schweighäuser; Schweighäuser 1799b, 420), 'sentiments' (Sharp 1914, 134), 'attitude of mind' (Oldfather), 'Erlebnis' (Bauer 1963, $\beta \dot{\alpha} \pi \tau \omega)$ ) 'Gemütsart' (Berger and Colpe 1987, 269). Oepke's (1974, 535) translations 'uncomfortable manner of life' ('Unbequeme lebensweise') and 'persecution' ('Verfolgung') clearly indicate conduct or persecution, as do possibly also Whittaker's $(1984,89)$ 'consequences' and Long's $(2002,110)$ 'condition.' Hartmann under-

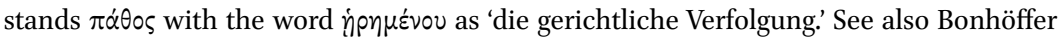
1911, 41 n. 2.

72 See also what Gager $(1983,77)$ writes on the passage without discussing the word $\pi \dot{\alpha} \theta \circ \varsigma$ : "as the sequel makes clear, far from offering any criticism of such converts [to Judaism], he presents them as models for the full acceptance of Stoicism. These comments need not be interpreted so as to make Epictetus an admirer of Judaism." 
expect, say, the habit which, according to Epictetus, makes Galileans fearless. This reading would make better sense in Epictetus' philosophy, but it would require a textual emendation ( $\varepsilon^{\prime} \theta \circ \varsigma$ pro $\pi \dot{\alpha} \theta 0 \varsigma$ ). Alternatively one can suppose that Epictetus borrows a word, which is strange for his philosophical terminology. I prefer this latter alternative, because a textual emendation is always a highly hypothetical solution and, therefore, the last alternative. Moreover, there seems to be even stranger features in the same passage, which-as we will see below-are probably due to borrowing.

It is not just $\pi \dot{\alpha} \theta 0 \varsigma$ but also its qualification, in tension with the context, that makes one suspect a loan expression. Epictetus qualifies $\pi \dot{\alpha} \theta 0 \varsigma$ as the $\pi \dot{\alpha} \theta 0 \varsigma$ of the one who is baptized and has made the choice. This expression assumes that persons have $\pi \dot{\alpha} \theta 0 \varsigma$ if they are both baptized and have made the choice. This is in tension with Epictetus' addition that a person should adopt $(\alpha \nu \alpha \lambda \dot{\alpha} \beta \eta)$ the $\pi \dot{\alpha} \theta 0 \varsigma$ of the one who is baptized and has made the choice. It becomes unclear why a person should adopt $\pi \dot{\alpha} \theta 0 \varsigma$, which she or he already has as a baptized person and as a person who has made the choice. The baptism and the choice qualifying $\pi \dot{\alpha} \theta 0 \varsigma$ do not fit with the requirement to adopt $\pi \dot{\alpha} \theta$ os. The tension between the verbs $\dot{\alpha} \nu \alpha \lambda \alpha \mu \beta \dot{\alpha} \nu \omega$ and $\alpha i p \varepsilon \dot{\omega} \omega$ is especially clear. In Epictetus' vocabulary, these terms bear practically the same meaning. The way Epictetus uses them in this passage creates a tautology.

The verb $\alpha \nu \alpha \lambda \alpha \mu \beta \alpha \dot{\alpha} v \omega$ in Epictetus' texts can be translated in several ways. The basic meaning is 'to take up' or 'to pick up' (Disc. 1.11.27; 3.25.4). Yet, this meaning can be adapted to various contexts. In some cases it refers to taking up clothes in order to put them on; hence, the meaning is 'to put on [clothes]' (Disc. 1.29.45; 4.8.15, 34). Three times the verb figuratively refers to memory: taking up words in order to remember them, hence 'to memorize' (Disc. 2.16.5), and taking up things from memory, hence 'to summon up' (Disc. 2.16.5; 3.25.1). Only the figurative meaning is possible in the passage we are dealing with. If the verb was understood in that way, Epictetus would say that the conduct is better when a Jew memorizes or summons up $\pi \dot{\alpha} \theta 0 \varsigma$. This, however, is anything but probable. Epictetus surely emphasizes mental operations as prerequisites for right conduct, and sometimes he speaks in a way such that the reader may forget that this is not enough. Theoretical study and meditation on the philosophical truths should be followed by practical training ( $\left.\sigma^{\circ} \sigma \eta \eta \sigma \varsigma \varsigma\right)$, as I noted above when discussing the habituation of the Galileans. This threefold curriculum is mentioned also in the context of the passage we are dealing with (Disc.2.9.13). So, merely 'summoning up' is not enough for the right conduct.

Fortunately, Epictetus adapts the verb $\alpha \nu \alpha \lambda \alpha \mu \beta \alpha \dot{\alpha} v \omega$ in other contexts. The most usual meaning of the verb is 'to adopt' a skill or doctrine (Disc. 1.20.13; 2.19 title; $3.5 .4 ; 3.21 .1,3,16 ; 3.26 .13 ; 4.8 .11)$, or a role $(\pi \rho \delta \sigma \omega \pi \circ v)$ and a way of life 
(Disc. 1.29.57; 3.20.6; 4.8.16; Ench. 37). This last meaning fits well with the passage we are dealing with. The passage seems to suppose the idea of persons acting their parts in the divine play. In some other passages, Epictetus clearly describes the universe as a theater (Disc. 1.29.41-47; fr. 11; Ench. 17), a common idea in antiquity. ${ }^{73}$ Note the similar vocabulary in the passage we are dealing with and the Stoic Aristo. According to Diogenes Laërtius (7.16o), Aristo com-

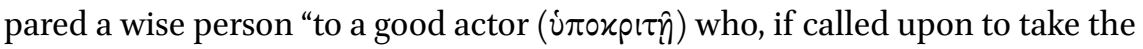
part ( $\pi \rho \delta \sigma \omega \pi$ ov $\alpha \nu \alpha \lambda \dot{\alpha} \beta \eta)$ of a Thersites or of an Agamemnon, will impersonate them both completely" (Trans. Hicks, LCL). Epictetus seems to suppose that $\pi \dot{\alpha} \theta 0 \varsigma$ is a substantial part of a Jewish role. Thus, one should adopt $\pi \dot{\alpha} \theta 0 \varsigma$ in order to properly play the part of a Jew in this theater called life.

It seems that in the present passage the verb aip's means quite the same thing as $\dot{\alpha} \nu \alpha \lambda \alpha \mu \beta \dot{\alpha} \nu \omega$. Basically, $\alpha i \rho \varepsilon \dot{\omega} \omega$ refers to different choices: people make choices in practical life (Disc. 1.28.6; 1.29.28; 2.22.8; 2.23.35; 3.24.44) and such judgments are based on rational choice (Disc. 2.2.20; 3.24.58; Ench. 32.3). Closest to our passage are the parts of the text where Epictetus speaks of a choice between a right and a wrong way of life (Disc. 1.9.24; 4.2.3,7; 4.6.13). An especially good analog for our passage is Discourses 4.2.3-7, where Epictetus

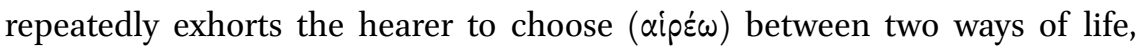

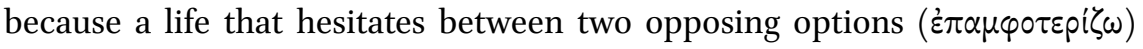
cannot progress.

(3) Choose ( $\dot{\lambda} \bigcirc 0 \hat{)})$, therefore, which you prefer; either to be loved just as much as you used to be by the same persons, remaining like your former self, or else, by being superior to your former self, to lose the same affection. (4) Because if this latter alternative is the better choice, turn forthwith in that direction, and let not the other considerations draw you away; for no man is able to make progress when he is facing both ways ( $\dot{\pi} \pi \mu \varphi \circ \tau \varepsilon \rho i \zeta \omega \nu)$. (5) But if you have preferred this course to every other, if you wish to devote yourself to this alone, and labour to perfect it, give up

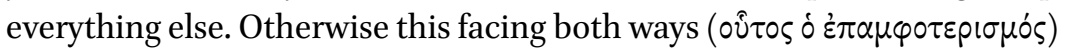
will bring about a double result: You will neither make progress as you ought, nor will you get what you used to get before. (6) For before, when you frankly aimed at nothing worthwhile, you made a pleasant companion. (7) You cannot achieve distinction along both lines, but you must

73 Cf. Plato, Phileb. 5ob; Maximus of Tyre, Dissertationes 1.1; Suetonius, Aug. 99.1; Marcus Aurelius 12.36; Diogenes Laërtius 7.16o. See also Bonhöffer (1911, 39 note 1); Billerbeck (1978, 50-51); Long 2002, 242-243; and Stephens 2012, 68-70. 
needs fall short in the one to the degree in which you take part in the other. If you do not drink with those you used to drink with, you cannot in their eyes be as pleasant a companion as you used to be; choose, therefore, whether you wish to be a hard drinker and pleasant to those persons, or a sober man and unpleasant. If you do not sing with those you used to sing with, you cannot be loved by them as you used to be; choose ( $\dot{\varepsilon} \circ 0 \hat{)})$, therefore, here also, which you wish.

Disc. 4.2.3-7; trans. Oldfather, LCL

This passage is closely reminiscent of the passage we are dealing with. Both discuss two alternative ways of life, but also hesitating ( $(\dot{\pi} \pi \mu \varphi \varphi \tau \varepsilon p i \zeta(\omega)$ between them. Yet, there is one terminological difference. The other passage admonishes the hearer to choose ( $\alpha i p \varepsilon \dot{c} \omega$ ) between one of the alternatives, while the other speaks of adopting $(\dot{\alpha} \nu \alpha \lambda \alpha \mu \beta \dot{\alpha} \nu \omega)$ one of them. In Epictetus' parlance it

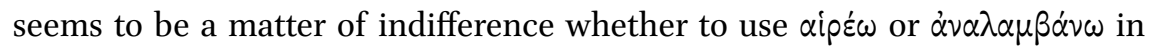
such contexts. Thus, it is tautological to say that the one hesitating between two faiths adopts $\pi \dot{\alpha} \theta 0 \varsigma$ after already choosing it. I am inclined to argue that aipéw is also a loan expression. I have a couple of reasons for this suggestion. First, this is the only time that Epictetus uses the perfect tense of the verb. Second, the verb $\alpha \nu \alpha \lambda \alpha \mu \beta \dot{\alpha} v \omega$ is the predicate in the clause and, therefore, more emphatic than the participle of $\alpha i p \varepsilon ́ \omega$. Third, as $\pi \dot{\alpha} \theta 0 \varsigma$ seems to be a loan, this is also quite naturally the case with its participle qualifier. Fourth, it remains unclear what the choice involves. I prefer to conclude that $\alpha i p \varepsilon \dot{\omega} \omega$ has lost its meaning in Epictetus' usage. This is understandable, if the verb was part of the loan expression.

Between $\pi \dot{\alpha} \theta$ os and the participle of the verb 'to choose' is the participle of the verb 'to baptize.' This verb is a hapax legomenon in the extant Epictetan texts. Between the probable loan expressions, the substantive pathos and the verb 'to choose,' it also seems to be a loan. Thus, the whole Greek expression $\tau \dot{o} \pi \dot{\alpha} \theta 0 \varsigma$

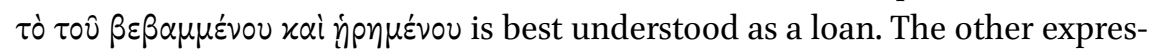
sion related to baptism, the substantive 'counterfeit baptist' ( $\left.\pi \alpha \rho \alpha \beta \alpha \pi \tau i \sigma \tau \eta^{\prime}\right)$, is also a hapax legomenon in the Epictetan corpus and otherwise rare in Greek. It should also be counted among the loan expressions. There are similar logical problems with baptism as with the choice, because both qualify $\pi \dot{\alpha} \theta 0 \varsigma$. The expression assumes that a person has $\pi \dot{\alpha} \theta \circ \varsigma$ as a result of baptism and choice. Yet, Epictetus still requires that a Jew should adopt $\pi \dot{\alpha} \theta$ os. This is certainly due to his view that a ritual is effective only if one interprets it rationally.

Epictetus' rationalizing tendency to interpret rituals is apparent when he speaks of the Eleusinian mysteries (Disc. 3.21.13-16). He considers the mysteries 
with piety, ${ }^{74}$ but does not refer to the conventional idea that mere attendance at them guarantees immortality. ${ }^{75}$ Actually, Epictetus believed neither in personal immortality nor in any effect based on attending such mysteries. ${ }^{76}$ According to Epictetus, the most important thing is the attitude of the attendees at the mysteries: "Only thus do the Mysteries become helpful, only thus do we arrive at the impression that all these things were established by men of old time for the purpose of education and for the amendment of our life" (Disc. 3.21.15; trans. Oldfather, LCL). Epictetus expects that the attendees at the mysteries understand rationally the moral message of the rite. A similar moral emphasis is visible when he speaks about baptism. The baptism itself is not important, but $\pi \dot{\alpha} \theta$ ○ shich one should consciously adopt. Actually, the wording Epictetus borrows betrays that baptism is comprehended as a mystery. Fritz Graf points out that the perfect participle is typically the linguistic form which is used in describing the effect of the mystery rites.

These rituals very often transformed the person who underwent them. The linguistic for this transformation is, as we saw, the participle perfect. These participles not only express the lasting effect of the rites of Bakchos, the Korybantes or Kouretes - the initiates actually have become Bakchoi and Korybantes, they have exchanged a former identity against one which is as close to their gods as a human being can get; and even having served as an Ephesian Kouretes left its imprint for the rest of one's life. ${ }^{77}$

In Epictetus' passage the perfect participle forms are $\beta \varepsilon \beta \alpha \mu \mu \varepsilon$ vov and

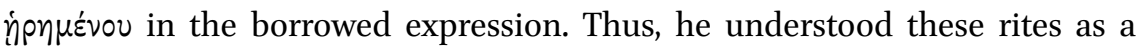
mystery cult, which he rationalized similarly to those of the Eleusinian mysteries. In both cases, Epictetus' treatment created a tension between the claimed ritual effect of the rites and Epictetus' moral requirement. However, in the case of the Eleusinian mysteries, it is clear which rites he refers to. In the passage we are dealing with, it is not so obvious. As stated above, I suggest that Epictetus speaks of Christians. Next, I will prove that this is quite probably the case by considering the different possible sources of the loan expressions.

\footnotetext{
74 Bonhöffer 1911, 321.

75 Klauck 2003, 103-105.

76 For Epictetus' view on the postmortal state, see Bonhöffer 189o, 65; 1894, 28; 1911, 293; Benz 1929, 36-41.

77 Graf 2003, 256; see also Graf 2003, 252.
} 


\subsubsection{Source of the Loans}

When searching for the source of the loans, it is natural to start with Epictetus' philosophical context. I look at some similar sounding expressions in philosophical texts. After that, I consider some Jewish texts. However, neither the former nor the latter provide any good alternative. Lastly, I show that certain Christian texts provide the closest analogies for Epictetus' loan expressions.

Emperor Marcus Aurelius provides an analogy for Epictetus' loan expression, as he uses the words $\pi \dot{\alpha} \theta \circ \varsigma$ and $\beta \dot{\alpha} \pi \tau \omega$ in the same context. Marcus Aurelius says that the divine element ${ }^{78}$ in the human being makes "a champion in the highest of championships - that of never being overthrown by any pas-

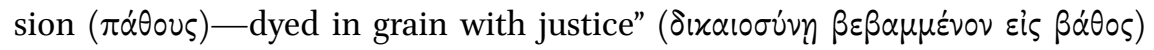
(Med. 3.4.3; trans. Haines, LCL). The translation suggests that the verb $\beta \alpha \dot{\alpha} \tau \omega$ denotes dyeing, a common metaphor in the ancient moral discourse. ${ }^{79}$ In this

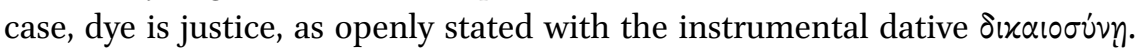
With the help of the divine element, one can metaphorically immerse oneself in justice and thus be blameless inside and out. In Greek, there is certainly an easy shift from dyeing to baptizing, as is evident from the Gospel of Philip, which for dyeing uses the Greek loan word $\beta \alpha \pi \tau i \zeta \omega$.

God is a dyer. As the good dyes, which are called "true," dissolve with the things dyed in them, so it is with those whom God has dyed. Since his dyes are immortal, they become immortal by means of his colors. Now God dips what he dips in water.

Gospel of Philip 61:14-2O; trans. ISENBERG

The author of the Gospel of Philip clearly makes use of the common ancient metaphor of dyeing and applies it to baptism. Marcus Aurelius, in contrast, does not make any shift to baptism, while Epictetus does not refer to dyeing in any way. An interpretation that would have Epictetus use dying metaphorically makes things too complex: it would introduce a new metaphor (dye) inside the existing metaphor (Jew). Moreover, Marcus speaks of $\pi \dot{\alpha} \theta \circ \varsigma$ in its usual Stoic sense as denoting vicious emotions, while Epictetus indicates something positive. ${ }^{80}$ Marcus admired Epictetus and knew his writings (Med. 1.7.3, 4.41, 7.19, 11.34), but he does not comment on Epictetus' words concerning Jews

78 This interpretation of the philologically difficult sentence is based on Farquharson's (1968b, 56o) solution.

79 Farquharson 1968b, 561. For the meaning of dyeing for $\beta \dot{\alpha} \pi \tau \omega$, see Ferguson 20o9, 43-46.

8o Some manuscripts of Marcus' text read $\beta \varepsilon \beta \lambda \alpha \mu \mu \varepsilon$ vov $\varepsilon i \varsigma$ $\pi \dot{\alpha} \theta 0 \varsigma$ (something like "caught in

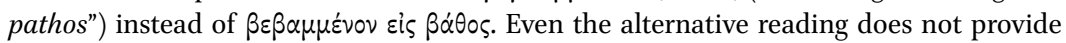
any effective analogy for Epictetus, as it suggests a negative meaning for $\pi \dot{\alpha} \theta \circ$ s. Moreover, 
and baptism. Therefore, Marcus' writings do not help to clarify the source of Epictetus' words.

Epictetus' terminology of a performance refers to acting in a play and possibly to rhetorical skills. In rhetoric, $\pi \dot{\alpha} \theta 0 \varsigma$ means the emotion that the speaker should expediently excite and steer (Aristotle, Rhet. 1356a, 1378a-1389a). In the De sublimitate, Pseudo-Longinus says that $\pi \dot{\alpha} \theta 0 s$ is one of the sources of sublimity, as it does not denote anything base like pity, sorrow, or fear (8.1-2). Epictetus also shuns these emotions, usually referring to them with the word $\pi \dot{\alpha} \theta 0 \varsigma$. They are the result of philosophical errors properly exhibited in tragic plays: "For what are tragedies but the portrayal in tragic verse of the sufferings $(\pi \dot{\alpha} \theta \eta)$ of men who have admired things external?" (Disc. 1.4.26; trans. Oldfather, LCL). In the Epictetan passage that we are concerned with, $\pi \dot{\alpha} \theta 05$ cannot mean emotions but something that is intimately joined with a conduct or way of life. These things were usually called $\hat{\eta} \theta 0 \varsigma$ in the art of rhetoric. ${ }^{81}$ Moreover, in the art of rhetoric it would be meaningless to qualify $\pi \dot{\alpha} \theta 0 \varsigma$ with baptism and choice. Therefore, the loans do not stem from the art of rhetoric.

The fact that Epictetus speaks of a $\pi \dot{\alpha} \theta 0 \varsigma$ that is characteristic of Jews makes it natural to search for the origin of the loans in Judaism. The word $\beta \varepsilon \beta \alpha \mu \mu \varepsilon v o v$ is in the perfect tense denoting 'a completed action, the effects of which still continue in the present. ${ }^{\prime 2}$ Thus, Epictetus does not indicate renewed purification rites ${ }^{83}$ but a single baptism, which has an ongoing effect, seemingly in the form of the $\pi \dot{\alpha} \theta 0 \varsigma$. In the Jewish context, a single baptism would mean a proselyte baptism. According to the Talmud, conversion to Judaism happened through circumcision, proselyte baptism and sacrifice (e.g., b. Ker. ga), but the last part was waived after the destruction of the temple (7O CE). Before the circumcision and the proselyte baptism, the convert was asked about the reason of the conversion (b. Yebam. $47 \mathrm{a}-\mathrm{b}) .{ }^{84}$ Is this the choice that Epictetus mentions?

For several reasons it is problematic to accept that Epictetus speaks of a proselyte baptism. First, this would be the first reference to the practice. Even if

there is no mention of dye or baptism, as $\beta \lambda \dot{\alpha} \pi \tau \omega$ replaces $\beta \dot{\alpha} \pi \tau \omega$. Lastly, one can note that the alternative reading hardly makes sense in its larger context.

81 See, e.g., Kraftchick 2001, 49-57.

82 Smyth 1984, 434 ( $(1945)$. This is the basic meaning of the perfect tense. Smyth also lists other meanings, but the context of Epictetus' passage does not indicate any of them. It is safest and most natural to keep the basic meaning here.

83 On the purification rites, see, e.g., Oepke 1974, 530-536; Thomas 1950, 1167-1172; Sanders 1992, 222-23o. See also Ferguson 2009, 79.

84 For more on the conversion, see, e.g., Moore 1955, 331-335; Bamberger 1968, 31-52; Schiffman 1985, 19-39; Cohen 1999, 198-238; Ferguson 2009, 76-82. 
this does not rule out the possibility of such a reference, ${ }^{85}$ it sheds a shadow on it. Second, why does Epictetus not speak a word about circumcision, which was certainly a better known mark of Judaism than proselyte baptism. ${ }^{86}$ Attempts to find circumcision in the text has not won favor. ${ }^{87}$ Neither have scholars accepted the theory that Epictetus' words reflect a practice of conversion without circumcision. ${ }^{88}$ These two arguments may not be fully decisive, while the third is: the passage does not speak of a non-Jew converting to Judaism. As I showed above, the common scholarly misunderstanding that Epictetus is speaking of proselytes is based on the emended text. This emendation has created the odd impression of uncircumcised proselytes, which the scholars have been at pains to explain. Instead of proselytes, Epictetus is speaking of two kinds of Jews: those who do not practice what they preach and those whoafter they have adopted the $\pi \dot{\alpha} \theta 0 \varsigma$ of one who is baptized and has made the choice-practice what they preach. There is no mention of a gentile becoming a Jew, but of a Jew becoming a real Jew. In this context, it is quite natural that circumcision is not mentioned. In this context the proselyte baptism is meaningless. Epictetus must be thinking of another baptism, which must be a single event indicated by the perfect tense.

Actually, Epictetus does not speak of one baptism but two. As we saw, there are real Jews whose conduct is in harmony with their words. However, he also speaks of baptism in terms of those whose words and deeds are not in harmony: "we are also counterfeit 'baptists' ( $\pi \alpha \rho \alpha \beta \alpha \pi \tau i \sigma \tau \alpha i)$ )." Thus, there are two baptized groups: those who keep words and deeds in harmony and those who do not. This may seem confusing, as people usually take the word $\beta \alpha \pi \tau i \sigma \tau \dot{n} \varsigma$ as meaning the one who baptizes in contrast to the baptized person. This confusion, however, stems from the Christian preconception. Actually, the word $\beta \alpha \tau \tau \iota \sigma \tau \dot{n}$ fits to those who baptize themselves. It is used with varying prefixes for several Jewish sects, which practiced repeating self-immersions. ${ }^{89}$ Epictetus hardly knew these remote sects. However, the names of the sects attest that the

85 Donaldson $(2007,391)$, who picks up the chronology, continues: "Still, there are good reasons for believing that the immersion was already a common practice. For one thing, it arises logically from the ritual immersions that formed a normal part of Jewish purity practice. Proselytes would eventually need to undergo the ritual in any event, and it is easy to see how the first instance of this could take initiatory significance."

86 On the general knowledge of circumcision, see, e.g., Schiffman 1985, 24-25; Sanders 1992, 213; Feldman 1993, 155-158.

$87 \quad$ Ysebaert (1962, 20 n. 2; see also Ferguson 2009,78 n. 99) proposes that $\pi \dot{\alpha} \theta 0 \varsigma$ denotes cir-

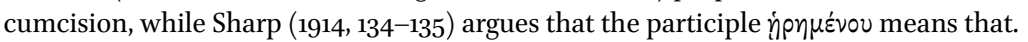

88 Conversion without circumcision is proposed by McEleney $(1974,332)$ but rejected by Nolland (1981, 179-182).

89 On the sects and their names, see Rudolph 1999. 
word $\beta \alpha \pi \tau i \sigma \tau \dot{\zeta} \varsigma$ can philologically denote both the one who takes the proselyte baptism and the one who practices repeated ablutions of mainstream Judaism (see, e.g., Lev. 15; Num. 19).

Epictetus assumes that all Jews are baptized, ${ }^{90}$ albeit in two different ways: the prefix $\pi \alpha \rho \alpha$ - makes plain that the other baptism is somehow invalid. ${ }^{91}$ This seems to reflect disputes over baptism: some Jews have an invalid baptism (section 21) while real Jews have a valid baptism (section 20). I have argued that the valid baptism can be nothing but the Christian baptism. While the word $\pi \alpha \rho \alpha \beta \alpha \pi \tau i \sigma \tau \alpha i$ can well denote the practicers of repeated ablutions, the perfect tense of $\beta \varepsilon \beta \alpha \mu \mu \varepsilon v$ vo cannot. Because the latter cannot be the proselyte baptism, the next alternative for a definitive baptism, performed once and for all, is the Christian baptism. This creates a picture where the baptized person with $\pi \dot{\alpha} \theta 0 \varsigma$ is a Christian while the counterfeit baptists are Jews. This scenario is anti-Jewish, and it betrays that Epictetus' loans are from a Christian source.

It does not matter if $\beta \varepsilon \beta \alpha \mu \mu \varepsilon$ vov is interpreted as the middle or the passive voice. In basic grammar teaching, they are usually differentiated sharply, but actually their nuances can be quite close to each other. ${ }^{92}$ In Acts 9:18, Paul is baptized (passive), but in Acts 22:16 Ananias admonishes Paul with a word in the middle voice: "Get up, be baptized ( $\beta \dot{\alpha} \pi \tau \iota \sigma \alpha l)$ and have your sins washed away, calling on his name."93 Thus, the middle voice can be used for the Christian baptism, too. The middle voice emphasizes the role of the person who takes baptism or lets it happen. Even a clearer reflexive meaning for the middle voice is possible, as self-baptism is not entirely unknown in early Christianity (see the Acts of Paul and Thecla in ANF 8:49o). Without speculating further about Christian baptismal practices, I summarize that the voice of $\beta \varepsilon \beta \alpha \mu \mu \varepsilon$ vov is of no consequence for its interpretation as a Christian baptism.

The idea of real and counterfeit baptisms corresponds to the Jewish-Christian relationship in the second century. There are examples of baptismal rivalry between the Jews and the Christians. ${ }^{94}$ According to Luke, John's baptism is insufficient (Acts 19:3-6). Justin Martyr makes plain that Christians do not accept Jewish ablutions but prefer the Christian baptism (Dial. 14.1; 19.2). This is similar to Epictetus' words, though chronological reasons restrain Epictetus'

\footnotetext{
$90 \quad$ Rightly Wander 1998, 167.

91 This is the earliest occurrence of the word $\pi \alpha \rho \alpha \beta \alpha \pi \tau$ $\sigma \tau \dot{\eta} \zeta$. Later we encounter it in the church fathers, who use it to refer to the persons who commit schismatic baptisms (Lampe 1961, $\pi \alpha \rho \alpha \beta \alpha \pi \tau 1 \sigma \tau \eta \dot{\zeta}$ ).

92 See Smyth 1984, 390-398.

93 For the discussion on this middle voice, see Porter 2002.

94 Rudolph $(1999,482)$ speaks of a rivalry between Christian and proselyte baptism.
} 
dependence on Justin. Moreover, the word $\beta \alpha \pi \tau \imath \sigma \tau \eta \dot{\zeta}$ and its derivates are philologically a Christian phenomenon, as they occur only in Christian texts - with two exceptions. These exceptions are Epictetus and Josephus. In Epictetus, it seems to be a Christian loan, while Josephus only uses it when speaking of "John called the Baptist" (Ant. 18.116; my trans.). Possibly Josephus also was dependent on a Christian source. Justin also speaks of a choice in the context of baptism. According to him, converts are baptized so that they become chil-

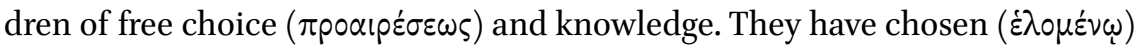
the rebirth ( 1 Apol. 61.10.). Justin speaks of Christ's $\pi \dot{\alpha} \theta 0 \varsigma$, meaning his suffering (e.g., Dial. 74.3; 97.3), but not in the context of a baptized Christian.

There are closer analogies for $\pi \dot{\alpha} \theta 0 \varsigma$ in the epistles of Ignatius of Antioch, a contemporary of Epictetus. For Ignatius, $\pi \dot{\alpha} \theta 0 \varsigma$ is an important concept which, one way or another, is always combined with Christ's suffering $(\pi \dot{\alpha} \theta 0 \varsigma){ }^{95}$ Christ's $\pi \dot{\alpha} \theta 0$ s is central for the Christian communities (see, e.g., the introductory salutations in Ign. Eph. and Ign. Trall.). It also ensures the effectiveness of baptism. As Christ was baptized, he cleansed water through his suffering (Ign. Eph. 18.2). ${ }^{96}$ Ignatius also speaks of choice and $\pi \dot{\alpha} \theta 0$ s in the same context. He says that Christians should freely choose ( $\alpha \dot{v} \theta \alpha i p \varepsilon ́ \tau \omega \varsigma)$ death and thus adhere to Christ's suffering (Ign. Magn. 5.2). Ignatius himself likes to imitate Christ's suffering in his death (Ign. Rom. 6.3). A heretic, in contrast, is not in harmony with $\pi \dot{\alpha} \theta 0 \varsigma$ (Ign. Phld. 3.3). For Ignatius, $\pi \dot{\alpha} \theta 0 \varsigma$ is exclusively the virtue of an orthodox Christian. Ignatius distinguishes between a real Christian and a Christian by name only (Ign. Rom. 3.2; Ign. Magn. 4). Thus, $\pi \dot{\alpha} \theta$ os is a marker defining the group of real Christians. In the Gospel of Philip, a similar distinction is made in terms of baptism.

If one goes down into the water and comes up without having received anything and says, "I am Christian," he has borrowed the name with interest. But if he receives the holy spirit he has the name as a gift.

Gospel of Philip 64:22-26; trans. ISENBERG, revised

The examples in Ignatius' epistles and the Gospel of Philip do not fully fit with Epictetus, who distinguishes between a Jew and a real Jew. However, it is interesting that there is a distinction between a counterfeit and a real adherent, even in terms of baptism. This shows that the distinction in Epictetus' texts was possible in Christian parlance. On the other hand, Ignatius differs from Epictetus, as the former does not present Christians as Jews. Ignatius'

95 Paulsen and Bauer 1985, 21; Schoedel 1985, 85-86; Brown 2000, 33-37.

96 Paulsen and Bauer 1985, 42. 
relationship to Judaism is critical, but even this criticism has similarities with Epictetus' words. In the spirit of Epictetus, Ignatius criticizes the conflict between Christian words and Jewish practice: "It is outlandish to proclaim Jesus Christ and practice Judaism. For Christianity did not believe in Judaism, but Judaism in Christianity" (Ign. Magn. 10.3; trans. Ehrman, LCL; cf. Ign. Phld. 6.1) ${ }^{97}$ Interestingly, in the same context Ignatius reminds that conduct is reflected in the popular designation: "Let us learn to live according to Christianity. For whoever is called by a name other than this does not belong to God" (Ign. Magn. 10.1). Moreover, Ignatius presented Christianity as a mystery cult (Ign. Eph. 12.2; 19.1), ${ }^{98}$ which is similar to Epictetus. As we saw earlier, Epictetus interpreted baptism as a moral lesson, as he did with the Eleusinian mysteries. I also showed that Epictetus' wording of the Christian ritual closely follows the expressions used in the mystery cults.

Epictetus' expressions- "the $\pi \dot{\alpha} \theta 0 \varsigma$ of the person who has been baptized and has made the choice" and $\pi \alpha \rho \alpha \beta \alpha \pi \tau i \sigma \tau \alpha i$-seem to be loan expressions that he does not fully incorporate, as there remains the tension noted above. Even single words betray that they do not belong to Epictetus' normal usage. I showed earlier that $\pi \dot{\alpha} \theta 0 \varsigma$ has an unusual meaning, that the words $\beta \dot{\alpha} \pi \tau \omega$ and $\pi \alpha p \alpha \beta \alpha \pi \tau i \sigma \tau \eta \dot{s}$ are hapax legomena in the Epictetan corpus, and that the perfect tense of the word aipéw occurs only here. The contents of the loan expression seemingly refer to Christianity. There are good Christian analogies for the supposed loan expressions, especially in the writings of Ignatius of Antioch, although one cannot pinpoint any unambiguous source for Epictetus' loans. Ignatius' suffering, however, makes sense as one meaning of $\pi \dot{\alpha} \theta 0 \varsigma$ in Epictetus' loan. Epictetus' words would refer to a Christian who is ready to suffer because of her or his beliefs. Such a Christian maintains the harmony between words and deeds. This interpretation is also in accord with what Epictetus says of Galileans-meaning, as we saw, Christians - and their fearless exposure to violence. The requirement that a Jew should also live like a Jew is found in Paul (Rom. 2). Paul also speaks of a Jew who has adopted Greek customs (Gal. 2:12-14). Though these texts are close to Epictetus, there is no clear link to Paul. The idea that one should overcome the conflict between theory and practice or between words and deeds is more or less clearly present in ancient literature in general (cf., e.g., Thucydides $2.8 ; 4.67 ; 5.55 ; 6.18$ ). A further analogy for Epictetus' words is found in Revelation: "I know the slander on the part of

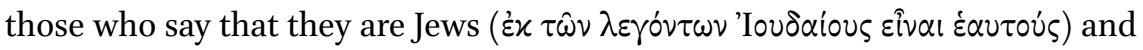

\footnotetext{
97 On Ignatius' view of Judaism, see Wilson 2004, 162-164; Robinson 2009 offers an even more profound perspective.

98 Harland 2009, 47-49.
} 
are not, but are a synagogue of Satan. Do not fear what you are about to suffer $\left(\ddot{\alpha} \mu \dot{\varepsilon} \lambda \varepsilon_{\varepsilon \iota \varsigma} \pi \dot{\alpha} \sigma \chi \varepsilon เ \nu\right)$ " (Rev. 2:9-10). The common features with Epictetus are the counterfeit Jews and suffering -if Epictetus' $\pi \dot{\alpha} \theta 0 \varsigma$ is interpreted as such. Although there is no exact parallel to Epictetus' loan words, they seem to suit Christian parlance.

Epictetus' words about Christians who are real Jews undoubtedly reflect a Christian self-understanding. This self-understanding - seen in the New Testament (Rom. 9:6-8), not to speak of later Christian literature ${ }^{99}$ - has a taste of Christian suprasessionist theology. Epictetus, however, does not present Christian self-understanding as a theological reconstruction but as an ethnic definition. Christians are Jews, whom he compares with Syrians and Egyptians. This is possibly not a misunderstanding on Epictetus' part. Scholars have often seen the Bar Kokhba revolt as a milestone, namely, the definitive point at which the Christian and Jewish ways clearly parted. ${ }^{100}$ Epictetus wrote before this revolt. While 'Galileans' undoubtedly refers to the geographical ori-

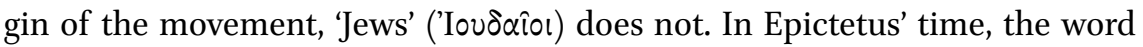
'Iouঠoîo no longer denoted only the inhabitants of Judea, the Judeans, but a

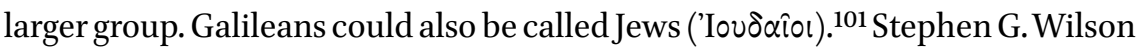
notes that the shift from geography and ethnicity ('Judean') to include people with other backgrounds ('Jew') opened a possibility for "the opportunistic appropriation of Jewish terminology and identity by dissident groups such as the early Christians." ${ }^{102}$ It seems that Epictetus' source has utilized this possibility in describing Christians as real Jews.

\subsubsection{Conclusions on Epictetus' Views on Christians}

Epictetus' views on Christians are often ignored. In particular, his Discourses 2.9.19-21 has not gained the attention it deserves. This is due to the difficulties in the text and the unfortunate emendations in the standard editions, which have misled many scholars into putting it in the category of Jewish proselyte baptism. The other reason is the weight of Adolf Bonhöffer's authority among scholars. Bonhöffer was probably the most distinguished scholar on Epictetus ever. Questioning him is a scholarly risk. I have taken this risk and maintain with A. A. Long that Bonhöffer tended to overemphasize Epictetus'

\footnotetext{
99 Feldman 1993, 196-200; Wilson 1995, 295-296.

100 Schiffman 1985, 75-78; Wilson 1995, 287-288, 299.

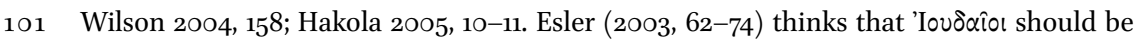
translated as 'Judeans,' but he admits that a Judean can also bear another geographical definition.

102 Wilson 2004, 159.
} 
doctrinal orthodoxy. ${ }^{103}$ This made him blind to the nuances in two passages on Christians.

Discourses 4.7.6 suggests that Epictetus knew Christians and their use of canons in habituation. The passage on Jews and real Jews (Disc. 2.9.19-21) utilizes Christian views and refers to baptism. Epictetus even borrows expressions from an unknown Christian source, textual or not. Both passages have received only superficial mentions, and deep analyses have been non-existent before my study. While deepening the understanding of Discourses 4.7.6, my analysis radically changes the picture of Discourses 2.9.19-21. I argue that the dominant reading of the passage is based on an unnecessary emendation of the text. The original text cannot speak of a non-Jew becoming a Jew, but a Jew becoming a real Jew. Therefore, the one-time baptism of the real Jew cannot refer to proselyte baptism. Instead, the only alternative is Christian baptism. The distinction between the counterfeit Jew and the real Jew seems to reflect Christian suprasessionist theology. The closest analogies for Epictetus' expressions are in the letters of Ignatius of Antioch, but no exact source can be attested. What is interesting in these two passages is the fact that Epictetus refers to Christians in passing. Granted that these passages do not betray any interest in Christianity per se, they do betray a self-evident knowledge of them, even among the audience. Epictetus does not explain who these Christians are or what their beliefs are. He seems to expect that his audience knows enough to understand his points. He even expects that the audience knows the Christian suprasessionist theology, which proclaims Christians as the real heirs of Judaism. Thus, the passing references to Christians indicate a surprisingly profound knowledge of Christians. Everything is mentioned in passing without hostility or contempt.

These findings reopen the discussion of Epictetus' relationship to Christians, which Adolf Bonhöffer shut down a century ago. The discussion, however, should be framed anew. Bonhöffer was right when he supposed that Epictetus would not have supplemented his philosophical system with Christian thoughts. His Discourses, however, shows that Epictetus used different motives from those of everyday life to illustrate his Stoic philosophy. Christians were presented as examples of fearless people whose words and deeds are in harmony. As Epictetus even uses some expressions from Christian sources, one can legitimately ask if there are even more references to Christians - or even Christian loans - in the Discourses. The case dismissed by Bonhöffer, I suggest, should be reframed in the following manner. First, it is unnecessary to limit the study to Epictetus' relationship to the New Testament. There is much more

103 Long 2002, 36. 
early Christian literature that is relevant for the comparison. Epictetus' $\pi \dot{\alpha} \theta 0 \varsigma$ has a good equivalent in Ignatius' epistles. Second, after Mörth's, Bonhöffer's, and Sharp's evaluations, one should not simply pick up parallels and make claims of dependences in a parallelomanic way. This was Zahn's deficiency. In many cases, the similarities between Epictetus' and Christian texts can be explained by their common cultural and linguistic background, that is, without forgetting the philosophical elements in the Christian literature. ${ }^{104}$ On the other hand, the fact that Epictetus cites Christian expressions increases the probability that some similarities are due to Epictetus' contact with Christians.

In order not to fall into parallelomania, one should concentrate on such Epictetan passages that include a special hint, for example the quiet waiting of the cross in Discourses 2.2.19-20. In the context of these sections, Epictetus blames those who incite judges in court, as this procedure will just ruin the case. On the other hand, if one likes to provoke the judges, why not keep quiet: "Why do you mount the platform at all, why answer the summons? For if you

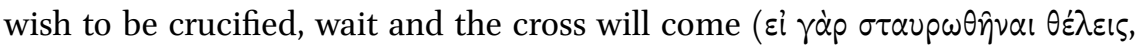

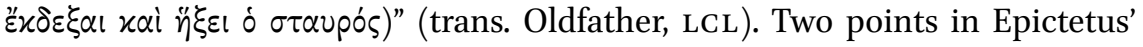
words attract interest. First, one should wait for the cross without answering the summons, like Jesus who did not "answer, not even to a single charge, so that the governor was greatly amazed" (Matt 27:14). Jesus' silence became paradigmatic, as attested by the wide use of Isa 53:7 as a prophecy foretelling Jesus. There are several references to the following words of Isaiah in early Christian literature (Acts 8:32; 1 Clem. 16; Barn. 5.2; Justin, 1. Apol. 50.1-11). ${ }^{105}$

He was oppressed, and he was afflicted, yet he did not open his mouth; like a lamb that is led to the slaughter, and like a sheep that before its shearers is silent, so he did not open his mouth.

Isa $53: 7$

104 Some examples illustrate this. In Discourses 1.2.3, Epictetus speaks of a person who goes and hangs himself $(\dot{\alpha} \pi \varepsilon \lambda \theta \dot{\omega} \nu \dot{\alpha} \pi \dot{\gamma} \gamma \xi \alpha \tau 0)$. Even Sharp $(1914,3)$ speculates that this has something to do with Judas, whose suicide is reported in a similar phrase (Matt 27:5). I think that Epictetus' aorist is naturally understood as a gnomic one and not as a reference to some person, which Sharp also understands. Thus, there is no real dependence. Discourses 2.20.21 includes the phrase $\dot{\varepsilon} \pi \dot{i} \gamma \omega \omega \sigma \varsigma \tau \hat{\eta} \varsigma \dot{\alpha} \lambda \hat{\eta} \theta \varepsilon i \alpha \varsigma$, which is not found in classical philosophy (Saarinen 2016, 45) but appears in 1 Tim 2:4 and Titus 1:1. However, the phrase is used by Diogenes Laërtius (7.42) and Sextus Empiricus (Math. 7.259), both of whom use it for epistemological matters, like Epictetus. Thus, I suggest that Epictetus is dependent on philosophical usage instead of Christian terminology.

105 Cf. also 1. Pet 2:21-25, which extensively uses Isa 53 (though not exactly verse 7 ). On the use of Isa 53 in early Christian tradition, see, e.g., Elliott 200o, 546-548. 
Second, Epictetus' students were from well-to-do families, presumably Roman citizens and other upper-class people for whom the cross was no real threat. Admittedly, there were rare cases when citizens were punished by the cross. Yet, "there was a distinction between the punishments suffered by citizens and slaves, and those of higher rank suffered less severe penalties than those of lower rank." 106 To be sentenced to death on the cross is just a theoretical or symbolical threat for Epictetus' students. Just before the reference to the cross, Epictetus presents Socrates as an example. Socrates did not die on the cross. Does Epictetus hint at Jesus as an example? A further analysis of this and possibly other passages may reveal if there are more contacts between Epictetus and early Christians in addition to Discourses 2.9.19-21 and 4.7.6.

In his references to Christians, Epictetus is not as polemical as Tacitus, Suetonius, and Pliny. While Pliny thought that Christianity is madness (amentia) (Ep. 10.96.4), Epictetus held a different view. Epictetus thought that Christians and madmen had a similar lack of philosophical grounds for fearlessness, but he did not lump these groups together. He admits that Galileans bravely attained virtuous conduct through habituation. In this respect, Christians are braver than the common people, who are not trained for a fearless encounter of threats. Thus, Epictetus' statement is quite a laudable one. This raises the question of the relationship between early Christian religion and ancient philosophy. In a way, Epictetus counted Christians as being above-average people, close to the level of philosophers. Yet, while Christians were not madmen, they were not fully philosophers either. They did not belong to the multitudes but to the Jews who practice what they preach. Christians can thus be compared to real Stoics. Epictetus put Christians in the category of "other," but it is probable that this categorization also led him to be benevolent to the Christians. Gerard J. Boter has convincingly demonstrated that Epictetus shows kindness toward laymen in philosophy, as they err unknowingly.107 In Epictetus' view, Christians are the noblest among the laymen, as they-without adequate philosophical knowledge even-have attained virtues through habituation.

Epictetus shows that otherness does not always mean hostility. This fact is seen again when we proceed some decades, from the beginning of the second century to the end of it. While the Christians still belong to the category of "other" in their views, the pictures painted by Marcus Aurelius, Lucian, and Galen are somewhat sympathetic.

106 Cook 2014, 362. In his book, Cook extensively discusses the practice of crucifixion in antiquity.

107 Boter 2010. 


\subsection{Christians and Philosophers at the End of the Second Century}

In this section I am going to study what Marcus Aurelius, Lucian, and Galen wrote about Christians. Before I dig deeper into their texts, I take a general look at the Christians in the society at that time, at the end of the second century. I also make a brief summary of Celsus' views. His work The True Word has a reputation of calling the Christians' beliefs base and stupid, but even a short look reveals that this is a rhetorical strategy in a situation where Christians were rising. During the second century, Christian philosophers and teachers were flourishing around the Empire: Basilides in Alexandria, Justin Martyr and Valentinus in Rome, Irenaeus in Lyon-just to mention a few. They became so visible in the intellectual sphere that Christians also met with philosophical criticism, as is evident in Celsus' treatise The True Word. Celsus' case is a good reminder of not taking every statement at face value. One should also note the rhetorical tactic which leads the author to represent and choose arguments in a certain way. There were enough unfavorable stories to pick from in order to present Christians in a questionable light. An example is a female character in Apuleius' Metamorphoses, who is probably a Christian:

That vile woman lacked not a single fault. Her soul was like some muddy latrine into which absolutely every vice had flowed. She was cruel and perverse, crazy for men and wine, headstrong and obstinate, grasping in her mean thefts and a spendthrift in her loathsome extravagances, an enemy of fidelity and a foe to chastity. Furthermore she scorned and spurned all the gods in heaven, and, instead of holding a definite faith, she used the false sacrilegious presumption of a god, whom she would call "one and only" (quem praedicaret unicum), to invent meaningless rites to cheat everyone and deceive her wretched husband, having sold her body to drink from dawn and to debauchery the whole day.

Apuleius, Metamorphoses 9.14; trans. HANSON, LCL

Simon Gathercole opens the earlier scholarly discussion on this passage by suggesting that Apuleius is really referring to Christians. He thinks this not only due to the monotheism mentioned, but also because of the early wine drinking (assumed to refer to the Eucharist) and lexical resemblances to Tacitus' account of Christians; together these tip the balance in favor of a Christian reference. ${ }^{108}$ If Apuleius referred to Christians, the account is an exaggerated and negative one meant to inspire something close to a horror story. In the horror stories, Christians were associated with the old topos of vicious nocturnal

108 Gathercole 2017, 285-287. 
rites. ${ }^{109}$ Minucius Felix had one of the characters of his dialogue recount grotesque tales of infanticide, cannibalism, obscure rites, and promiscuous sexuality. Christians "establish a herd of a profane conspiracy, which is leagued together by nightly meetings, and solemn fasts and inhuman meats" (Minucius Felix, Oct. 7-8; ANF 4:177-178).

Andrew McGowan has rightly pointed out that these circulating stories probably have nothing to do with the actual practices of the labeled groups. The labeling "expresses a fantasy whose real substance is the anxiety thus expressed about the internal structure and external boundaries of society."110 Minucius refers to Marcus Cornelius Fronto, a famous orator, as one source of the rumors; he also says, however, that they belong to the general talk of people. ${ }^{111}$ Rude criticism and malicious storytelling indirectly prove the rising threat that Christianity posed. For Celsus, Christianity was not only a social but also a philosophical menace. ${ }^{112}$

Celsus' literary reply to Christianity was a symptom of the progress his opponents had made over the previous hundred years; when Christianity was little more than a secretive sect of Judaism, there had been no need for philosophical opposition. By the time Celsus and the other polemicists began their attack, however, their enemy had become a force to be reckoned with. ${ }^{113}$

Generally, scholars date Celsus' The True Word to the late 17os, but the evidence is not conclusive. Some scholars date it a few years or even a few decades later. ${ }^{114}$ In any case, it mirrors the atmosphere at the end of the second century. It is debated whether Celsus was an Epicurean or Platonist. Even Origen seems to be uncertain of Celsus' philosophical affinities (Origen, Cels. 4.54), but the argumentation tends to the Platonic. ${ }^{115}$ However, there is no debate over the philosophical character of the work, despite its stigmatizing storytelling.

109 See Kahlos 2013 and Rauhala 2013. Later these stories were associated with Gnostics (see, e.g., Eusebius, Hist. Eccl. 4.7.9-11 and Benko 1980, 1083-1089).

110 McGowan 1990, 441.

111 On the relationship between Fronto and Minucius' text, see Baldwin 199 o.

112 Gathercole 2017, 299.

113 Hargis 1999, 15.

114 Pichler 1980, 94-97; Hargis 1999, 20-24; Cook 20oo, 23-24; Arnold 2016, 3 n. 9. Hargis defends a much later dating (around 200) while Mitchell (2007, 235 n. 94) modestly proposes the 18 os. Mitchell reliably shows that the text cannot be dated earlier than 177 .

115 On the discussion of Celsus' philosophical background, see Dörrie 1967, 52-53; Pichler 1980, 27-38; Cook 200o, 18-22. Andresen (1955, 72-78) also discusses Celsus' relationship to Stoicism. 
For example, Celsus reports that Jesus is not born of a virgin ( $\pi \alpha \rho \theta \varepsilon$ vं $0 \varsigma)$, but

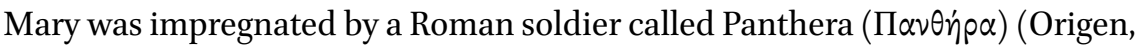
Cels. 1.32). ${ }^{116}$ In general, Celsus reported what he actually knew of Christians and Christianity, ${ }^{117}$ but in an uncompromisingly unfavorable light. Rhetorically Celsus tries to show that there is a gaping chasm between Christianity and the Greco-Roman culture, pressing time and again that Christianity is philosophically nonsensical and that Christians are even encouraged to despise understanding and take things without any grounds. Origen paraphrases Celsus' point as follows:

He next proceeds to recommend, that in adopting opinions we should follow reason and a rational guide, since he who assents to opinions without following this course is very liable to be deceived. And he compares inconsiderate believers to Metragyrtæ, and soothsayers, and Mithræ, and Sabbadians, and to anything else that one may fall in with, and to the phantoms of Hecate, or any other demon or demons. For as amongst such persons are frequently to be found wicked men, who, taking advantage of the ignorance of those who are easily deceived, lead them away whither they will, so also, he says, is the case among Christians. And he asserts that certain persons who do not wish either to give or receive a reason for their belief, keep repeating, "Do not examine, but believe!" and, "Your faith will save you!" And he alleges that such also say, "The wisdom of this life is bad, but that foolishness is a good thing!"

Origen, Cels. 1.9; trans. ANF 4:399-400

Originally Moses has deluded some "herdsmen and shepherds" into believing that there is only one God (Origen, Cels. 1.23). For Celsus, the problem is not monotheism itself but its exclusive Christian (and Jewish) form. He states that contrary to the Christian view, the supreme god is worshiped by different names in various nations and there are also several lower deities which must be worshiped. In this opinion, he followed the standard Platonic theology of his time. ${ }^{118}$ Against this, Christianity is vulgar doctrine "and on account of its vulgarity and its want of reasoning power, obtained a hold only over the igno-

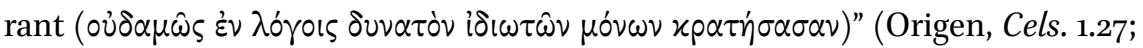
trans. ANF 4:408). Jesus' disciples were "the very wickedest of tax-gatherers and sailors" (Origen, Cels. 1.62; trans. ANF 4:423-424), and this is mirrored in

116 On the text-critical problems in this passage, see Arnold 2016, 85-87.

117 Hargis 1999, 20.

118 Hargis 1999, 54-59. 
Christianity and its followers. Celsus represents Christianity as a radically and consciously alliterate faction.

The following are the rules laid down by them. Let no one come to us who has been instructed, or who is wise or prudent (for such qualifications are deemed evil by us); but if there be any ignorant, or unintelligent, or uninstructed, or foolish persons, let them come with confidence. By which words, acknowledging that such individuals are worthy of their God, they manifestly show that they desire and are able to gain over only the silly, and the mean, and the stupid, with women and children.

Origen, Cels. 3.44; trans. ANF 4:481-482

In sum, Christians have a low social background and, therefore, they cannot understand philosophical truths. ${ }^{119}$ They are "utter boors," as Cook puts it, following Celsus' view. ${ }^{120}$ Asking if Celsus maliciously undervalued the philosophical capacity of the Christians, Heinrich Dörrie then answers: "Unfortunately not." Dörrie maintains that the chasm between the two camps was really so deep that they could not understand each other. ${ }^{121}$

On the other hand, Jeffrey W. Hargis laments these kinds of conclusions.

Scholarship on Celsus has historically tended to treat him as an impartial observer, perhaps forgetting that his was a polemic work intended for rhetorical effect, not a record for church historians of a later era. ${ }^{122}$

When one considers Celsus' work from a rhetorical point of view, the situation seems different. First of all, it is symptomatic that Celsus considers Christianity to be worth a philosophical response. It is surely possible to philosophically examine an unphilosophical subject. However, a close reading of Celsus' rhetoric reveals that the educational differences between Christians and philosophers are not as great as he tries to maintain. According to Johannes Arnold, the rhetorical key to The True Word is the passage which reveals that every Christian is not just stupid-minded and unlearned. ${ }^{123}$

\footnotetext{
119 Hargis 1999, 51-54.

120 Cook 200o, 88.

121 Dörrie 1967, 48.

122 Hargis 1999, 6o.

123 Arnold 2016, 403-405.
} 
He continues, moreover, to linger over the accusations which he brings against the diversity of sects which exist, but does not appear to me to be accurate in the language which he employs, nor to have carefully observed or understood how it is that those Christians who have made

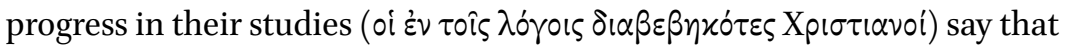
they are possessed of greater knowledge than the Jews; and also, whether they acknowledge the same Scriptures, but interpret them differently, or whether they do not recognise these books as divine.

Origen, Cels. 5.65; trans. ANF 4:571

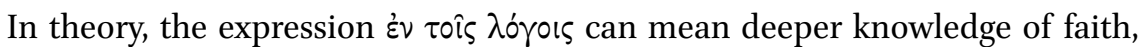
Christian doctrine, or Scriptures, but Arnold argues for general higher education, and he is not alone. ${ }^{124}$ In other words, Celsus admits here that there are Christians who have a philosophical education. What follows in Celsus' work after this remark is a comparison of Christian and Platonic views, which suggests that his Christian audience has at least a basic knowledge of Plato's philosophy. ${ }^{125}$ Celsus asks the Christians who can to follow his arguments (Origen, Cels. 7.45; cf. 6.3). Obviously he is suggesting that there are some Christians who fulfill the requirements; otherwise he would not be addressing them. These Christians are even capable of independently gaining more knowledge (Origen, Cels. 4.61; 7.58). According to Arnold, the further Celsus' work proceeds, the more philosophical expertise he calls into play and, consequently, the narrower audience he has in mind. ${ }^{126}$

It is true that there were a lot of common, uneducated Christians, but even Celsus' own text betrays that there were also educated ones. It is his rhetorical tactic that created an insuperable barrier between Christians and educated philosophers. Celsus did not really think that Christianity "obtained a hold only over the ignorant" (my emphasis). Origen himself notes immediately after these words that Celsus' words are an exaggeration. He adds that Celsus himself admits "that there were amongst them some persons of moderate intelligence, and gentle disposition, and possessed of understanding, and capable of comprehending allegories" (Origen, Cels. 1.27; trans. ANF 4:408).

Celsus' case gives the proper frame to see how other non-Christian philosophers considered Christians. Marcus Aurelius and Lucian ${ }^{127}$ did not lack a

124 Arnold 2016, 403-404. Similarly, see Andresen 1955, 184-185; Pichler 1980, 155; and Chadwick in his translation of Origen's work.

125 Arnold 2016, 428 n. 65; see also Pichler 1980, 153-169.

126 Arnold 2016, 427-430.

127 Lucian and Celsus seem to have been in contact (see, e.g., Mitchell 2007, 232-236). 
critical eye toward Christians, but in the manner of Celsus they acknowledged the different philosophical strains that existed among this group. And Galen openly praised Christians in relation to philosophy. Next, I will take a look at what these three said about Christians.

Marcus Aurelius: Christians and the Military Metaphor of Philosophy

Fronto was the tutor of Emperor Marcus Aurelius (reigned 161-180), with whom he had a lively correspondence. ${ }^{128}$ Thus, Marcus Aurelius surely had access to the horror stories of Christians. There is a saying in the Meditations where the common themes of these stories come up:

Yet to have the intelligence a guide to what they deem their duty is an attribute of those also who do not believe in Gods and those who fail their country in its need and those who do their deeds behind closed doors.

MARCUS AURELIUS, Med. 3.16; trans. HAINES, LCL

C. R. Haines straightforwardly assumes that this passage "must undoubtedly refer to the Christians, who were accused precisely of these three thingsatheism, want of patriotism, and secret orgies." He also assumes several other passages $($ Med. $1.6 ; 7.68 ; 8.48 ; 8.51)$ to be indirect references to the Christians. ${ }^{129}$ Simon Gathercole rightly comments: "Marcus may have had Christians in mind in some of these places, but the references are too general to be certain."130 This fits also with the horror stories referred to in Marcus' passage above. As noted, these were stock stories used to label various groups regarded as deviant. Thus, there is no solid ground for discussion, except in one case. Keeping in mind that Marcus was under the influence of malicious stories and that there were harsh persecutions in Lyon and Vienne during his reign (Eusebius, Hist. eccl. 5.1-4), ${ }^{131}$ his overt reference to Christians is decent. He wrote about them only once in his Meditations:

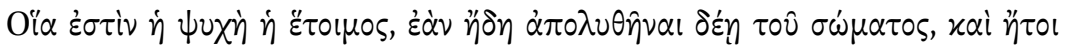

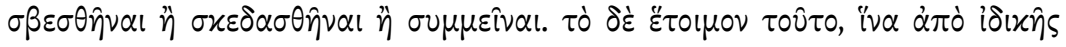

128 Birley $1987,69-86$.

129 Haines 1916, 63 n. 1. See also Haines 1916, 383-385.

130 Gathercole 2017, 287 n. 35 .

131 On Christianity in relation to Marcus Aurelius, see, e.g., Birley 1987, 256-265. 


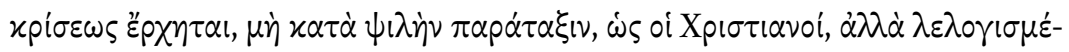

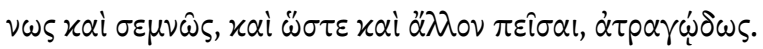

What a soul is that which is ready to be released from the body at any requisite moment, and be quenched or dissipated or hold together! But the readiness must spring from one's own judgment, and not be the result of mere opposition as is the case with the Christians. It must be associated with deliberation and dignity and, if others too are to be convinced, with nothing like tragic actors.

MARCUS AURELIUS, Med. 11.3; trans. HAINES, LCL; slightly revised

Christians are associated with the words "the mere opposition," but only as an exemplary case. Syntactically, the words "the mere opposition" are contrasted (indicated by $\mu \dot{\eta}$ and $\alpha \lambda \lambda \dot{\alpha}$ ) with the previous words of one's own judgment and the following words on deliberation and dignity. After dignity ( $\sigma \varepsilon \mu \nu \omega \hat{)})$, the sentence is possible to understand either as a further contrast to the "mere opposition" or independently as a continuing list of recommended characteristics. I prefer the latter interpretation, as it is hard to see the words $\kappa \alpha \tau \dot{\alpha} \psi(\lambda \dot{\eta} \nu$ $\pi \alpha \rho \dot{\alpha} \tau \alpha \xi i \nu$ in contrast with the word $\dot{\alpha} \tau \rho \gamma \gamma \dot{\omega} \delta \omega \varsigma$. It is widely acknowledged that $\pi \alpha \rho \alpha \alpha \alpha \xi ı \zeta$ basically denotes the battle array, and that it is employed in metaphorical use here. ${ }^{132}$ Marcus Aurelius metaphorically refers to soldiers who face death strenuously, that is, with energy and strength. This strenuous fighting surely happens without tragic lamentation. ${ }^{133}$ Fighting in battle does not contrast with a non-tragic way of facing death. Therefore, the expression $\varkappa \alpha \tau \dot{\alpha} \psi \mid \lambda \dot{\eta} \nu \pi \alpha \rho \alpha \dot{\tau} \tau \alpha \xi i \nu$ is qualified only in contrast with one's own judgment ( $\dot{\alpha} \pi \dot{0}$

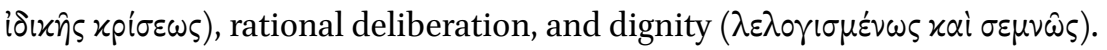

Some scholars have doubted that Marcus originally spoke of Christians, considering instead the possibility that there is a later addition to the text. ${ }^{134}$

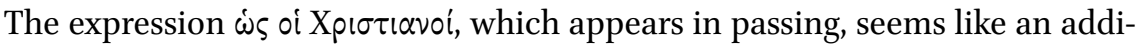
tional thought, as it does not grammatically fit in with the rest of the clause. The text qualifies the manner of the agency ( $\varkappa \alpha \tau \dot{\alpha} \psi(\lambda \dot{\eta} \nu \pi \alpha \rho \dot{\alpha} \tau \alpha \xi(\nu)$ with a substantive, as though Christians were some kind of manner (aiming to say that Christians shared the manner), but the syntactical construction is incorrect.

\footnotetext{
132 Brunt 1979, 488; Birley 1987, 264; Motschmann 2002, 265.

133 Birley $(1987,264)$ understands the word $\dot{\alpha} \tau \rho \alpha \gamma \omega \dot{\omega} \delta \omega$ after Farquharson's translation as 'without histrionic display,' but Marcus Aurelius' references to tragedies make clear that there is a question of lamentation (Med. $3.7 ; 3.8 ; 5.28 ; 9.29 ; 11.6$ ) (see Brunt 1979, 487 n. 11). The last reference is the clearest and has weight, as it belongs to the close textual context of Med. 11.3.
}

134 See also Gathercole 2017, 288-291. 
As the expression is incorrect, one can therefore ask whether it is original at all. In his edition of Marcus Aurelius' text, C. R. Haines put the words $\dot{\omega} \varsigma$ of

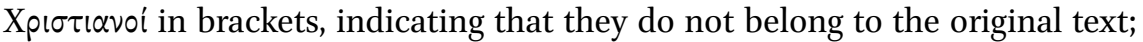
he thought that it is a margin comment later inserted into the text. ${ }^{135}$ However, A. S. L. Farquharson pointed out several parallels of Marcus' syntactical incongruencies. ${ }^{136}$ Later P. A. Brunt accepted Farquharson's note, but also followed Haines' omission. Brunt thought that a reference to the Christians does not suit Marcus Aurelius' thought. ${ }^{137}$ Anthony Birley, on the other hand, expressed that he was "totally unconvinced" by Brunt's arguments. ${ }^{138}$

Brunt provided four arguments to prove the inauthenticity of the expression. First, as the word $\pi \alpha p \dot{\alpha} \tau \alpha \xi ı$ lऽ actually means 'battle array,' it would be absurd to describe Christians in this light. ${ }^{139}$ Birley rightly rebuts that Christians widely used military metaphors, and thus the metaphor here is by no means absurd. ${ }^{140}$ Farquharson and Birley exemplified the sense of $\pi \alpha p \alpha \dot{\tau} \tau \xi \xi \varsigma$ and its cognates in the Christian usage. They referred to a letter (cited by Eusebius) on the martyrs in Lyon and Vienne during Marcus Aurelius' reign. ${ }^{141}$ According to the letter, God's mercy led the army ( $\left.\dot{\alpha} \nu \tau \varepsilon \sigma \tau \rho \tau \eta^{\prime} \gamma \varepsilon \iota\right)$ and marshaled pillars against

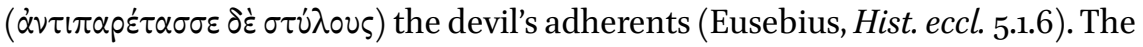
deacon Sanctus remained steadfastly opposed ( $\dot{\alpha} \nu \tau i \pi \alpha \rho \varepsilon \tau \dot{\alpha} \xi \alpha \tau 0)$ to the torturers (Eusebius, Hist. eccl. 5.1.20).

Second, Brunt claims that references to the lamentation of the tragic actors do not fit with the Christians, "who accepted their fate calmly and even joyfully."142 Actually, it is difficult to associate tragic lamentation with the disciplinary contempt of death in a battle array, even if one omits the words $\omega \varsigma$ oi

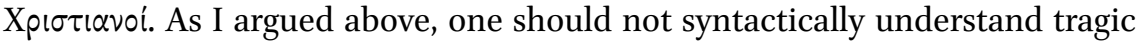
lamentation in contrast to a battle array. Marcus contrasts the standing in the battle array with deliberation and dignity. The non-tragical death is just an additional qualification of ars moriendi, and one should not understand it

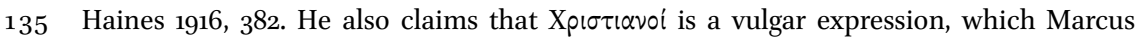
Aurelius could not have used, while admitting that Pliny and Lucian did use it. Thus, the claim is not very strong, and Farquharson $(1944,859)$ rightly rejects it.

136 Farquharson 1944, 859.

137 Brunt 1979, 484-498.

138 Birley 1987, 264. Rutherford (1989b, 178) claims that Brunt's claim of inauthenticity "is less persuasive." This is surprising, as Rutherford accepts Brunt's stance with caution in his study published in the same year $(1989,188)$ !

139 Brunt 1979, 488.

140 Birley 1987, 264. On the Christian use of military metaphors, see Chapter 4 in this book.

141 Farquharson 1944, 859; Birley 1987, 264.

142 Brunt 1979, 487 n. 11. 
in opposition to the standing in the battle array. Thus, unlike Brunt suggests, Marcus does not claim that Christians in the battle array lament tragically.

Third, Brunt rightly assumes that Marcus Aurelius is primarily thinking of suicide in the Meditations 11.3. He thinks that it would be difficult to find here an allusion to Christians, who only in exceptional cases denounced themselves in order to become martyrs. ${ }^{143}$ However, as Brunt himself notes, it is easy to bring martyrdom and suicide into parallel relation, as martyrs preferred death to apostasy. The Christian readiness to die was well known, as Pliny and Epictetus attest. I cannot see any argument against the originality of the text.

Fourth, Brunt points out that Christian martyrs opposed Marcus Aurelius' government. As Brunt reasons, it would therefore be odd if Marcus Aurelius reminded himself not to die like Christians who oppose the Emperor. Brunt rightly claims, however, that Marcus Aurelius is speaking of an opposition to divine rationality: death should happen according to that reason $(\lambda \varepsilon \lambda \circ \gamma(\sigma \mu \varepsilon \dot{\varepsilon} \omega \varsigma)$ which is also the divine rationality permeating the universe (cf. Med. 7.9). Marcus Aurelius thus blames Christians for opposing rationality, instead of opposing his government, which is not even hinted at in the context. In sum, Brunt's arguments against the originality are not convincing.

Cornelius Motschmann skillfully associates Marcus Aurelius' words with those of Epictetus in Discourses 4.7.6. ${ }^{144}$ The fact that there really is something similar should not come as a surprise, considering that Marcus Aurelius knew Epictetus' writings (Med. 1.7; 4.41; 11.34, 36). According to Epictetus, Christians face death fearlessly, not due to rational reasons, but out of habit ( $\ddot{\varepsilon}_{0} \circ \varsigma$ ) achieved by training. It is quite apparent that Marcus Aurelius also contrasts Christian opposition with reasonable judgment. In describing the motivation of Christians, he does not use Epictetus' technical term $\varepsilon^{\prime} \theta 0 \varsigma$, but the analogical idea, mapped from the military metaphor deployed in this context, onto Christian believers. The battle array thus stands for the continual training which "instilled a habit of obedience to instructions, and which, combined with a fear of punishment, kept a soldier in his place in his unit's formation."145 Similarly, Marcus Aurelius assumes that Christians were like soldiers who do not withdraw, thanks to their committed training. William O. Stephens aptly assumes that Marcus "may have meant that the Christians were not making their own individual choices to die as martyrs, but were being pressured into

\footnotetext{
143 Brunt 1979, 491-493.

144 Motschmann 2002, 266. See also Gathercole 2017, 291 n. 56.

145 Goldsworthy 1996, 251.
} 
it by their peers in the cult, like soldiers trained to line up and get bowled over like pins." ${ }^{146}$

The military metaphor gives the impression that Christians were drilled to face death. Their steadfastness did not arise out of their own rational judgment

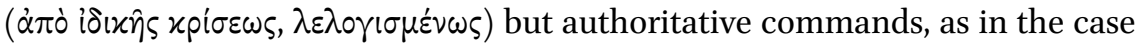
of trained soldiers. Moreover, Christians did not die with dignity ( $\sigma \varepsilon \mu \nu \omega \hat{\omega} \varsigma)-a$ word that also bears religious overtones. ${ }^{147}$ These expressions make it explicit that these Christians were "others" to Marcus Aurelius, albeit clearly not in the sensational sense of Fronto. Interestingly, there were also Christians who discussed martyrdom in a critical tone. ${ }^{148}$ Marcus Aurelius' view was not necessarily far from the inter-Christian discussion, although the emperor lumped all Christian martyrs together.

The military metaphor reveals that Marcus Aurelius counted Christians on the same level as his soldiers. ${ }^{149}$ This means that the Christians were "others" in the same sense that soldiers were. Military pride in victories is seen as morally questionable (Med. 10.10), but Marcus Aurelius nonetheless honored his duty to command the army. ${ }^{150}$ Christians were-like soldiers-philosophically "others." It is, however, indicative that Marcus Aurelius described Christians by employing a military metaphor. These kinds of metaphors belonged to a long philosophical tradition. ${ }^{151}$ In spite of Marcus Aurelius' philosophical reservations toward war and soldiers, he used military metaphors in a positive sense: "Life is a war and a campaign in a foreign land" (Med. 2.17) during which one should stay on guard (Med. 2.7; 7.45). It is noteworthy that shortly after mentioning Christians, Marcus Aurelius reminds himself of his own guard duty:

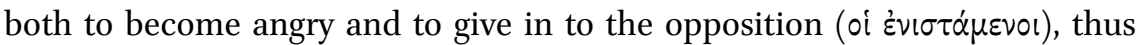
rendering one a deserter by leaving one's post (Med. 11.9).

Marcus Aurelius follows Epictetus' path: Christian conduct is outwardly acceptable and even laudable to the extent that soldiers are laudable. There is actually nothing wrong with standing resolute in the battle array, but rational opposition has an additional benefit, as it frees one from internal passions. Even if one-note the similarity of the expression with the passage

\footnotetext{
146 Stephens 2012, 28-29.

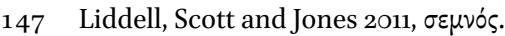

148 Dunderberg 2013.

149 One may ask if this has something to do with the probable fact that there were Christian soldiers in his army, who were claimed to have been present in witnessing a miracle. The miracle incident is communicated through both Christian and pagan sources. See, e.g., Helgeland 1979, 766-773, and Kovács 2009.

150 Birley 1987, 216-217.

151 Emonds 1963. See also Chapter 4.2 in this book.
} 
on Christians-stands in irrational opposition ( $\left.\alpha \dot{\alpha} \nu \alpha \lambda{ }^{\circ} \gamma \omega \varsigma \pi \alpha p \alpha \tau \dot{\alpha} \xi \eta \tau \alpha l\right)$, she or he is nevertheless psychologically an invincible acropolis (Med. 8.48). Christians are invincible, but they just lack the right principles to attain inner serenity. This is a moderate assessment, far from Fronto's horror stories or the "Romans' shock" of which Cook speaks.

\subsubsection{Lucian: Pseudo-philosophy of the Poor Wretches}

Lucian was a contemporary of Marcus Aurelius but died some years after him, as he once mentions the deification of Marcus Aurelius (Alex. 48). Lucian was a satirist who ridiculed the oddities of human life. Thus, though he was acquainted with philosophy, he was not a philosopher in the full sense of the word. ${ }^{152}$ Lucian mentions Christians in two of his numerous books, presenting Christianity as a mystery cult with certain affinities to philosophy. The mixture of philosophy and a mystery cult is not considered blame as such, as there was no clear-cut division between philosophy and religion in the ancient view. ${ }^{153}$ For example, Epictetus could praise the Eleusinian mysteries, as I showed above. Lucian's ridiculing tone, however, undoubtedly betrays that Christians are "others" whom at best he might pity: Christians are just poor wretches

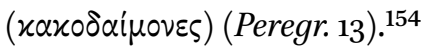

In the book Alexander the False Prophet, Christians are mentioned three times. Lucian tells a story of Alexander, a religious impostor, who scapegoats his adversaries by claiming that "atheists and Christians" crowd the whole area. ${ }^{155}$ According to Alexander, these suspicious persons blaspheme him and should be expelled with stones (Alex. 25). Later, Alexander begins his own mysteries with the outcry: "If any atheist or Christian or Epicurean has come to spy

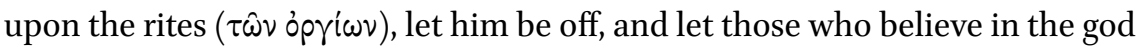
perform the mysteries ( $\tau \varepsilon \lambda \varepsilon i \sigma \theta \omega \sigma \alpha \nu)$, under the blessing of Heaven." ${ }^{156}$ He then adds ceremonially "Out with the Christians!" and the multitude responds "Out with the Epicureans!" (Alex. 38; trans. Harmon, LCL). ${ }^{157}$ The outcry expresses

\footnotetext{
$15^{2}$ Betz 1961, 4-5.

153 See, e.g., Betegh 2009.

154 Betz 1961, 11.

155 Victor $(1997,149)$ states that the "crowding" should not be understood as an overstatement of the situation in Pontus, the area where everything happens in the account. Victor shows that the New Testament (Acts 2:9; 1 Pet 1:1) and Pliny (Ep. 10.96) both report Christians there.

${ }_{15} 6$ Lucian interchangeably uses the words opp $p \downarrow \alpha$ and $\tau \varepsilon \lambda \varepsilon \tau \dot{\eta}$ to denote the mystery rites (Schuddeboom 2009, 66, 168-169). The latter is used just before the citation. The verb

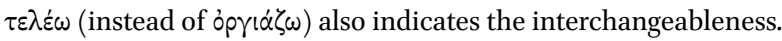

157 Outcries at the beginning of the mysteries were standard (Victor 1997, 156). Just the content of Alexander's outcry is exceptional.
} 
a hostility which possibly indicates religious rivalry with the Christian rites. ${ }^{158}$ As I noted above, the loan expression that Epictetus uses reflects a theology in which baptism was understood as a kind of mystery rite.

In Alexander the False Prophet, Lucian describes Christians as a minority that can be used as scapegoats. Lucian possibly was an Epicurean, but placing the Epicureans and the Christians in parallel does not lend any special sympathy toward the latter. ${ }^{159}$ At least there is no trace of it in the text. However, the paralleling itself is worth noting. As the paralleling of the Christians and the atheists reflect one strand of the popular notion (cf. Mart. Pol. 3.2; 9.2), ${ }^{160}$ the parallel with the Epicureans is also indicative. There really were some similarities, as both the Christians and the Epicureans challenged commonly accepted religious views. ${ }^{161}$ However, the paralleling of Christians with a philosophical school is noteworthy in a more general sense. In the following, I will show that this reflects the fact that Christianity was increasingly understood in terms of philosophy in the second century. ${ }^{162}$

A more detailed description of Christians is found in the book The Passing of Peregrinus. Peregrinus is a picaresque character who wanders as a Cynic philosopher, encounters Christians, and becomes popular among them. Lucian describes Christianity as a religious association, claiming that soon after the encounter Peregrinus became their $\theta 1 \alpha \sigma \alpha$ pX $\eta \varsigma$, a leader of their $\theta^{i} \alpha \sigma \circ \varsigma$ (Peregr. 11). The word $\theta i \alpha \sigma o \zeta$ is one of the many names for an association, which usually had a connection to a cult. ${ }^{163}$ Lucian also identifies Christianity more specifically by saying that it is a $\tau \varepsilon \lambda \varepsilon \tau \dot{\eta}$, a mystery cult of Eastern origin (Peregr. 11).164 The character of a religious association is strengthened when it is said that

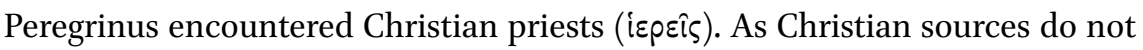

$15^{8}$ Victor $1997,155^{-156}$

159 See Betz 1961, 7. Victor (1997) claims that the paralleling of the Epicureans and the Christians originates in Alexander and not in Lucian, who could not parallel these two groups. Lucian, however, sketched a satirical image of Alexander and the words in Alexander's mouth should not be read as though Lucian would prefer this kind of paralleling. One should also note that Lucian's sympathy for Epicurus in Alex. is questionable, as it can be read ironically (Branham 1989, 181-210).

16o On the association between Christianity and atheism, see Walsh 1991.

161 On the similarities, especially in relation to the popular mind, see Simpson 1941. See also Glad 1995 .

162 See Benko 1980, 1097.

163 Goulet-Cazé 2016, 218-219. For a short and informative introduction on the associations, see Harland 2009, 26-29; Kloppenborg and Ascough 2011, 1-13. Pliny already saw Christian gatherings as associations (collegia) (Ep. 10.96).

164 Schuddeboom $(2009,67)$ constructs Lucian's meaning of the word more specifically: it denotes "the circle of regular participants," hence a "sect." 
know any Christian priest in the second century, Lucian just associates a word known in the cult associations at that time. ${ }^{165}$ Besides being a leader of the

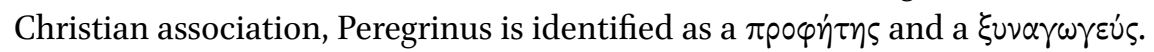
Although these are ordinary words in the Jewish and Christian texts, they do not necessarily have anything to do with these traditions. The word 'prophecy' and its cognates recur several times in the pagan context (e.g., Lucian, Alex. $11,22,24,40,43,55,60$ ) and even in the New Testament to refer to a pagan

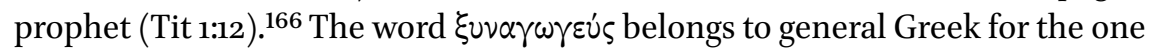
who assembles. Just to give an example, there were leaders of "synagogues" ( $\dot{\alpha} p \chi 1 \sigma 0 v \alpha \gamma \omega \gamma \gamma$ i) without any connection to Judaism or Christianity. ${ }^{167}$

The picture of a religious association is enriched by its philosophical character-or pseudo-philosophical, as Lucian ridicules Christians. He explains that Christians called Peregrinus "the New Socrates" (Peregr. 12). This is surely an ironic statement on the part of Lucian, but at the same time it betrays the fact that Christians associated themselves with philosophy. Socrates in this context is no surprise after reading Justin Martyr, who inferred that Socrates was Christian insofar as he was so closely associated with the divine Logos (1. Apol. 46.3). Lucian relays the fact that Christians admired and used philosophy, although he laughs at this. ${ }^{168}$ Marie-Odile Goulet-Cazé interestingly notes that even Peregrinus' own character speaks for the harmonization between philosophy and Christianity. He was even a Cynic and a Christian at the same time. ${ }^{169}$

I am inclined to associate the literary character of Christianity with philos-

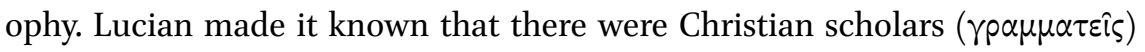
(Peregr. 11). ${ }^{170}$ Peregrinus explained their books and even composed new ones (Peregr. 11$){ }^{171}$ There surely can be books within a mystery cult (cf. Alex. 11), but the literate character is more easily associated with philosophy. Ilaria Ramelli rightly notes that Lucian "knew that Christianity in fact was not only a religion for simpletons, but an intellectual movement that was constructing itself as a philosophy in his day."172 Another feature which can be associated

165 Pilhofer 2005, 58.

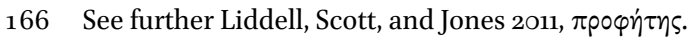

167 Kloppenborg and Ascough 2011, 311-312. See Pilhofer 2005, 6o; Goulet-Cazé 2016, 219-221.

168 Edwards 1989, 94.

169 Goulet-Cazé 2016, 224-226.

170 Christian scholars are already mentioned in Matt 13:52 (Betz 1961, 8). However, this word was also commonly known in the ancient world (Pilhofer 2005, 59).

171 There are apologies that are ascribed to Peregrinus and mentioned in the Christian sources (Pilhofer 2005a, 98-100). We do not know if this is the same person as the one mentioned in Lucian's treatise.

172 Ramelli 2015, 15 o. 
with philosophy is the interest in lawgivers. Lawgivers primarily refer to the political sphere, but the meaning of the word can be enlarged. What seems to be essential is the setting of rules, be it by God, who gives each man his wife (Epictetus, Disc. 2.4.10), ${ }^{173}$ or reason as a source of morality (Marcus Aurelius, Med. 4.12).

Lucian uses a satirical overstatement to say that Christians revered

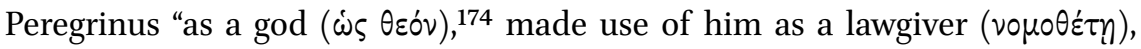
and set him down as a protector $(\pi \rho \circ \sigma \tau \dot{\alpha} \tau \eta \nu)$, next after that other, to be sure, whom they still worship, the man who was crucified in Palestine" (Peregr. 11; trans. Harmon, LCL). Later, Lucian identifies Jesus (without saying his name) as the first lawgiver, who promised an eternal life for those who live according

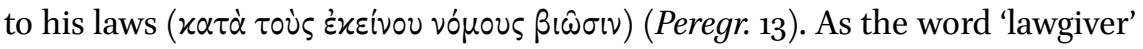
resonates with how the ancient world regarded older lawgivers like Solon and Lycurgus, Lucian uses this resonance to ridicule Christians who so easily make big claims. The pseudo-philosophical character of Christianity is expressed by saying that Jesus is a "crucified sophist" (Peregr. 13). The word 'sophist'

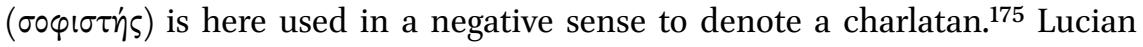
describes Jesus as a sophist who gave stupid laws to his followers. ${ }^{176} \mathrm{He}$ misled simple folk who were exposed to financial exploitation. This becomes clear after Lucian describes the energetic acts of Christians to free or at least to relieve Peregrinus' stay in prison:

They show incredible speed whenever any such public action is taken; for in no time they lavish their all. So it was then in the case of Peregrinus; much money came to him from them by reason of his imprisonment, and he procured not a little revenue from it. The poor wretches have

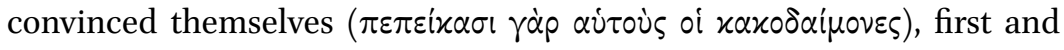
foremost, that they are going to be immortal and live for all time, in consequence of which they despise death and even willingly give themselves into custody, most of them. Furthermore, their first lawgiver persuaded them that they are all brothers of one another after they have transgressed once for all by denying the Greek gods and by worshipping

\footnotetext{
173 On the identification of the lawgiver, see Huttunen 2009, 78-79.

174 The translation "like a god" would suit Christians better.

175 Betz 1961, 11. Interestingly, Plato linked sophists with mysteries (Schuddeboom 2009, 27). See also the ironic characterization of Christianity as the "wondrous wisdom" (Peregr. 11).

176 Pilhofer (2005a, 64; 2005b, 105-107) thinks that the lawgiver is Paul and not the same person as the crucified sophist. Yet, Lucian says earlier that Peregrinus was a lawgiver "next after that other ... the man who was crucified in Palestine" (Peregr. 11; trans. Harmon, LCL). This indicates that Jesus was the lawgiver.
} 
that crucified sophist himself and living under his laws. Therefore they despise all things indiscriminately and consider them common property, receiving such doctrines traditionally without any definite evidence

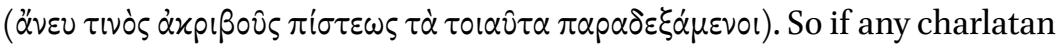
and trickster, able to profit by occasions, comes among them, he quickly acquires sudden wealth by imposing upon simple folk.

Peregr. 13; trans. HARMON, LCL

Jesus as a sophist opened the way for any kind of charlatan, including Peregrinus, to exploit people. There are, however, certain details of Christianity that are unrelated to the main claim of easy exploitation: belief in immortality, contempt of death, brotherhood, being an exclusive cult, and common property. Later Lucian assumes that Peregrinus ate something forbidden and thus broke the laws ( $\pi \alpha \rho \alpha v o \mu \eta \dot{\sigma} \sigma \alpha \varsigma)$ (Peregr. 16). It is easy to find parallels for these ideas in early Christian writings, but actually all of them are also found in ancient philosophy, even being an exclusive cult. ${ }^{177}$ In this light it is understandable that Lucian hastens to add that Christians accept these doctrines without adequate demonstration. They are pseudo-philosophers of a new mystery cult.

Lucian's irony belongs to his wish to describe Christians as an "other." The category of philosophy is the vehicle of his irony. Lucian makes plain that one cannot take Christians seriously in this category as they embrace doctrines "without any definite evidence." However, the basic tone is not abhorrent or aggressive — as it is in Tacitus, Suetonius, and Pliny—but pitying: Christians are "poor wretches" who are easily tricked. Their beliefs are a simple-minded mimicry of philosophy. Thus, Christians are the "others" of philosophy. This categorization is understandable in the historical context where many Christians themselves presented their faith as a true philosophy. As I will demonstrate in what follows, one finds the same category in Galen as used by Lucian.

\subsubsection{Galen and the Others of Philosophy}

After Hippocrates, Galen was the most famous medical doctor of antiquity. He died around 200, or some years after, so that his sayings on Christians are dated to the turn of the 2nd century. A profound student of philosophy and medicine,

177 On Pythagoras, see, e.g., Diogenes Laërtius, 8.10, 13, 19, 28. Some have tried to reconstruct what Peregrinus may have eaten, but Goulet-Cazé (2016, 223-224) rightly notes that Lucian just speculates about forbidden food. Thus, Lucian did not actually know the reason why Peregrinus left Christianity. Whether Lucian's story mirrors some Jewish-Christian sect, Montanism, or something else is difficult to prove (see Ramelli 2015, 146-148; Goulet-Cazé 2016, 223-224). 
Galen served for a while as a court physician to the emperor Marcus Aurelius. ${ }^{178}$ Four texts by Galen on Christians have been preserved, two in Greek and two in Arabic translations. In addition, there is one Greek text discussing the creation of the world with a reference to Genesis. I argue that this can also be read in relationship to Christianity.

In the book De pulsuum differentiis, Galen discusses with a certain Archigenes who, following the Stoics, assumes eight qualities of the pulse without giving adequate reasons for it. Galen marvels at those prominent people whose view is worth following. ${ }^{179}$

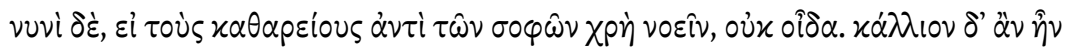

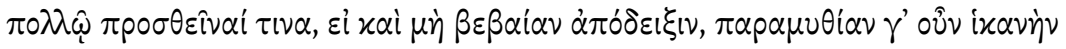

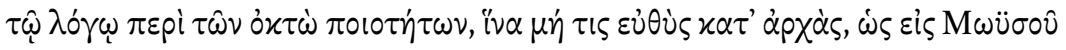

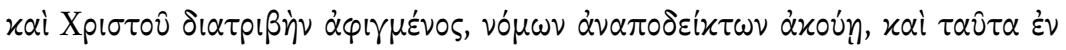

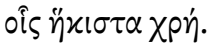

Now, however, I wonder whether one ought to take the "prominent" people in place of the wise; it would at any rate be much better to add to the statement about the eight qualities, if not a cogent demonstration at least a reassuring and sufficient explanation so that one should not at the very beginning, as if one had come into the school of Moses and Christ, hear talk of undemonstrated laws, and particularly where this is least appropriate.

De pulsuum differentiis Kühn 8, p. 579; trans. WALZER, ${ }^{180}$ slightly revised

The school of Moses and Christ is placed on the same level with Archigenes, both being said to put forward undemonstrated claims. Two things are worth noting here. First, Galen speaks of a $\delta\left\llcorner\alpha \tau \rho ı \eta^{\prime}\right.$. The word has several meanings, but here it can mean nothing but a philosophical school. ${ }^{181}$ This definition as a school is not praise from Galen's side, but proves rather that he saw the Christians as comparable with the other philosophical schools, or at least comparable to the Stoic school of Archigenes. ${ }^{182}$ Second, there is one school of Moses and Christ. It is actually a Christian school, as both Moses and Christ can be associated only with the Christians. ${ }^{183}$ Galen did not confuse Christians

\footnotetext{
178 See, e.g., Martin 2004, 109-110.

179 Walzer 1949, 45-46.

18 o Walzer 1949, 46.

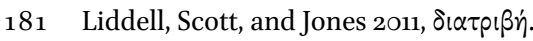

182 See Flemming 2017, 185 .

183 Similarly Gathercole 2017, 292-293.
} 
and Jews; otherwise he speaks of them as separate groups. He is familiar with the distinctively Christian standards of morality (see below) while also certainly knowing that Moses "gave laws to the Jewish people" (Ibn Abu Usaibi'ah, History of Physicians, p. 151; trans. Kopf). Galen returns to the school of Moses and Christ later in the same book. He is criticizing the strict adherence of a certain school as it prevents one from acquiring new insights. Therefore, it is of no use to discuss with them. Even the people in the school of Moses and Christ are more ready to change their minds.

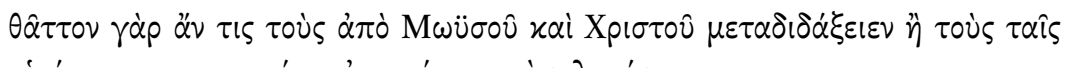

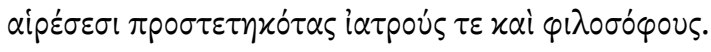

One might more easily teach novelties to the followers of Moses and Christ than to the physicians and philosophers who cling fast to their schools.

De pulsuum differentiis Kühn 8, p. 657 ; trans. WALZE R, ${ }^{184}$ slightly revised

Here Galen does not literally speak of a Christian school, but of people "from Moses and Christ." However, it is obvious that he is again speaking of the school, as the comparison to medical and philosophical schools implies. The comparison is possibly a sarcastic remark meant to blame other physicians and philosophers; even Christians who are famous for their obstinacy (cf. Pliny's and Marcus Aurelius' views) are more easily converted than dogmatic philosophers. ${ }^{185}$ There is still one fragment preserved in Arabic where Galen blames Christians (and possibly also Jews) for accepting everything without any definitions:

If I had seen people who taught their disciples in the same way as the disciples of Moses and Christ were taught - that is, who ordered them to accept everything on trust - then I would not have given you any definitions.

IBN ABU USAIBI'AH, History of Physicians p. 151; trans. Kopf; slightly revised

In this text, Galen not only blames Christians for inadequate arguments but also reveals the basis upon which they present such arguments: trust—or faith, as one also can translate the Arabic word. ${ }^{186}$ One should not assume a contra-

184 Walzer 1949, 38.

185 See Sprengling 1917, 107.

186 As Walzer $(1949,15,49)$ translates this. 
diction between faith and reason, as Galen is ready to believe what is "said and

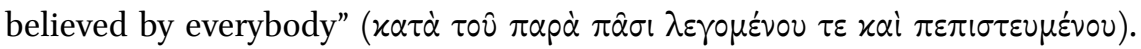
This he has been taught by Aristotle (De pulsuum differentiis Kühn 8, p. 579; trans. Walzer). ${ }^{187}$ The mistake is to take everything on faith. Galen traces the lack of demonstration back to Genesis, which was evidently known to many philosophers. ${ }^{188}$ In a fragment, Galen seems to focus on the wording of Genesis 1: Moses "wrote his books without adducing proofs, he merely said: God has ordered, or, God has said" (Ibn Abu Usaibi'ah, History of Physicians p. 151; trans. Kopf). A pagan rhetorician commented similarly on the word of God, though in the positive sense: "So, too, the lawgiver of the Jews, no ordinary man, having formed a worthy conception of divine power, gave expression to it at the very threshold of his Laws where he says: 'God said' - what?' 'Let there be light,' and there was light. 'Let there be earth,' and there was earth'” (Longinus, [Subl.] 9.9; trans. Fyfe, LCL).

There are clear assessments of Genesis in the De usu partium, where Galen aims at proving that "every part of the body is perfectly formed and arranged to fulfill its preordained purpose or function."189 In Galen's theology, it means that Nature, God or a demiurge - he uses these words interchangeably - is in control of creation. When commenting on the hair of the eyelashes, for example, he reflects on how the divine has functioned, and he also refers to Moses and Epicurus:

Did our demiurge simply enjoin this hair to preserve its length always equal, and does it strictly observe this order either from fear of its master's command, or from reverence for the god who gave this order, or is it because it itself believes it better to do this? Is not this Moses' way of treating Nature and is it not superior to that of Epicurus? The best way, of course, is to follow neither of these but to maintain like Moses the principle of the demiurge as the origin of every created thing, while adding the material principle to it.

De usu partium HELMREICH, p. 158; trans. WALZER ${ }^{190}$

Galen proceeds to show that God must have structured the eyelashes in a certain way, as material principles have their own limitations. It would not have

187 Walzer 1949, 46.

188 Walzer 1949, 20-23; Gager 1972.

189 Martin 2004, 120.

190 Walzer 1949, 11-12. 
been possible to make a human being out of stone just by willing it, as Moses thinks.

It is precisely this point in which our own opinion and that of Plato and of the other Greeks who follow the right method in natural science differs from the position taken up by Moses. For the latter it seems enough to say that God simply willed the arrangement of matter and it was presently arranged in due order; for he believes everything to be possible with God, even should He wish to make a bull or a horse out of ashes. We however do not hold this; we say that certain things are impossible by nature and that God does not even attempt such things at all but that he chooses the best out of the possibilities of becoming.

De usu partium HELMREICH, p. 158-159; trans. WALZER ${ }^{191}$

Galen discusses the details of the structure of the eyelashes and their attachment to the rest of the human body, for it is significant that the demiurge planted them in a cartilaginous part of the body: "If He had planted them in a soft and fleshy substance He would have suffered a worse failure not only than Moses but also than a bad general who plants a wall or a camp in marshy ground" (De usu partium Helmreich, p. 906; trans. Walzer). ${ }^{192}$ This is the last reference to Moses in Galen's book. Nothing implies that Galen is speaking only of the Jews when referring to Moses. ${ }^{193}$ As earlier noted, the reference to one school of Moses and Christ must be a reference to the Christians. It is logical that even these assessments of Genesis can be seen in relation to Christians, though one cannot exclude Jews. The simple explanations in reference to God's will are also similar to the simplicity of the "undemonstrated laws" in the school of Moses and Christ. Galen does not view Genesis very highly.

Despite his reserved or even ridiculing attitude toward Genesis, Galen discusses it in the same category as Plato's Timaeus. He associates Plato's demiurge with the biblical God without any hesitation. ${ }^{194}$ Galen admits that Moses is right in his belief in the demiurge; for this reason, he places the prophet on a higher level than Epicurus. But Genesis is just too simple, as it passes

\footnotetext{
191 Walzer 1949, 11-12.

192 Walzer 1949, 11-12.

193 Walzer $(1949,23)$ understands these texts as references to Jews, but without questioning this assumption.

194 Walzer 1949, 26.
} 
over the details of creation and attributes of God with impossible conditions. ${ }^{195}$ Dale B. Martin balances this critique with Galen's theology of the best possible world with its political implications: the teleological view was conservative, while the Jewish-Christian apocalypticism with its hope for a better world in the future was revolutionary. If God could break the limits of the possible, it would open a door to the impiety of thinking that God's creation is not perfect. ${ }^{196}$ There is, however, no criticism of the Christians for their apocalyptic or non-conservative views in the Galenic corpus. While Galen expressed philosophical criticism of their theoretical views, he saw nothing wrong with their actual practice or way of life. In a text preserved in quotations, Galen praised Christians in a way not seen before in the pagan texts.

Most people are unable to follow any demonstrative argument consecutively; hence they need parables, and benefit from them — and he (Galen) understands by parables tales of rewards and punishments in a future life ${ }^{197}$ _ just as now we see the people called Christians drawing their faith from parables [and miracles], and yet sometimes acting in the same way [as those who philosophize]. For their contempt of death [and of its sequel] is patent to us every day, and likewise their restraint in cohabitation. For they include not only men but also women who refrain from cohabiting all through their lives; and they also number individuals who, in self-discipline and self-control in matters of food and drink, and in their keen pursuit of justice, have attained a pitch not inferior to that of genuine philosophers.

Trans. WALZER ${ }^{198}$

The transmission of this passage raises questions of its authenticity of the text. It has been transmitted in two seemingly independent traditions, say, "Republican" and "Phaedonian." One tradition in Arabic maintains that this passage on Christians is actually a comment on Plato's Republic X. Another

195 Van der Eijk 2014, 351-354. Walzer (1949, 26) assumes that Galen refers to creatio ex nihilo when requiring the material principle to be counted. I think that Galen just refers to the limitations of different materials, so that God cannot create, say, a horse out of ashes.

196 Martin 2004, 123-124.

197 As one sees, this is a clarifying interpretation within the quotation. It was seemingly not clear enough as to what rumīz means. Walzer preferred "parable" ( $\pi \alpha \rho \alpha \beta\rangle \lambda \alpha i)$ but there are other alternatives discussed by Gero $(1990,405)$. This is of minor interest here, as Gero concludes: "The general intention of Galen's comment is in any case obvious enough."

198 The translation is based on several versions; see Walzer 1949, 15-16. The Syriac text was published as an English translation by Levi Della Vida (1950, 184). 
tradition transmitted in Arabic and Syriac speaks of a comment on Plato's Phaedo. ${ }^{199}$ Both traditions convey a roughly similar text, meaning that there must have been a common original, seemingly in Greek. Martin Sprengling claims that the Greek under the Arabic "is fairly apparent" and that it is Galen's Greek. Sprengling boldly maintains that "it would be an easy matter to retranslate Abulfeda's Arabic into Greek composed of Galen's own words and phrases."200 Scholars do not usually question the suggestion of a Greek original, but the idea of verbatim translation. The existence of two slightly different traditions and the differences even within both traditions show that the text has been revised. Probably close to the truth is Stephen Gero's cautious view that Galen really wrote something like this, which the remaining texts witness, but that some details are elaborated. Gero singles out the comment admiring sexual abstinence, which seems to contrast against Galen's more moderate view in other texts. ${ }^{201}$ However, one can assume that the transmitted texts express Galen's general tone, even if some details are later revisions.

One thing that connects this text to Galen's other texts on Christians is the claim that Christians do not follow demonstrative arguments. Their myths, however, seem to be a short cut to virtuous conduct. The idea fits with the structure of the tenth book of Plato's Republic, where there is the famous myth at the end. However, the idea that the myth is not literally true is not present in the tenth book. In Phaedo 114d, Plato hints that it is morally useful to believe in myths but leaves open whether they are literally true or not. Galen seems to remain within the non-literal tradition. ${ }^{202} \mathrm{He}$ saw the benefits of these tales, which he thought served the same ethical purpose as philosophical argumentation.

Though presenting Christians in an admirable light, Galen counts them among the oi $\pi \circ \lambda \lambda$ i, or common people. In this way, he certainly intended to put them in their right place. There were, however, features that elevated them above this category and, in other passages, Galen also seems to assume that one can include them within the philosophical categories. Genesis is placed in parallel with Plato's Timaeus, and Moses is at least placed on a higher level than

199 Walzer (1949) sees that the "Phaedonian" tradition is dependent on the "Republican" one. Thus, the former is a modification of the latter. Levi Della Vida (1950), in turn, is convinced that the traditions are independent. This view has won sympathy in the subsequent scholarly discussion. See Köbert 1956; Pines 1971, 73-83; Gero 199o; Gathercole 2017, 292-296.

200 Sprengling $1917,106$.

201 Gero 1990, 404, 407-411.

202 Walzer 1949, 6o-61, 70. It is not worth pinpointing any exact passage in Plato to which Galen refers (see Sprengling 1917, 108). 
Epicurus. There is a school of Moses and Christ comparable to the other philosophical schools. This certainly has something to do with how the Christians presented themselves. An anonymous Christian author around the year 200 criticizes some Christians for treating the Holy Scriptures without fear, eagerly seeking to find syllogisms in the Scriptures instead of learning what they declare. They even devote themselves to secular sciences like geometry, and study Euclid, Aristotle, and Theophrastus laboriously. The anonymous author supposes that some perhaps even worship Galen (Eusebius, Hist. Eccl. 5.28.14). This is clearly a polemical overstatement, although it is completely credible that some Christians were acquainted with Galen's works.

According to Gero, "there is no evidence that Galen puts the Christians and philosophers on the same level." ${ }^{203}$ This is simply not true, as Galen does speak of a Christian school. He did not approve of its doctrines that highly, but neither did he approve of Archigenes' Stoicism or the Epicureans. Loveday Alexander puts it aptly:

Galen places most of his Greek and Roman contemporaries, including the adherents of the philosophical and medical schools, on the same side of the gulf as the Jews and Christians. The essential point ... is that the "followers of Moses and Christ," whatever their deficiencies as philosophers, are in this respect no worse than-in fact may even be superior to - the adherents of the schools.... In fact, for Galen "the followers of Moses and Christ" are treated here as two among many contemporary schools which show a devoted - and in Galen's eyes culpable - loyalty to their own particular dogmas. ${ }^{204}$

I concur with Alexander's statement, adding only the minor comment that Galen-as I have argued above-did not speak of Jewish and Christian schools, but only a Christian school. There is, however, one aspect that separated Christians from other schools. While some Christians were educated in philosophy, others were ordinary people without any formal instruction in it. This is certainly one reason for Galen's vacillation between different views on Christians. In some sense, Christians were a school, but in another sense they were common people with a belief in myths. If one is to follow Pierre Hadot, it was not critical for a philosopher to have certain theoretical convictions,

\footnotetext{
203 Gero 1990, 407.

204 Alexander 1995, 65-66.
} 
but rather to have a brave life. ${ }^{205}$ In this light, it would have been natural to accept virtuous Christians as philosophers, but Galen resisted this idea. The Christians remained "others" to him, but certainly "others" of philosophy. They lived like "genuine philosophers" without being philosophers.

\subsection{Conclusions}

Richard Walzer maintains that Galen was the first philosopher in Rome to make a sympathetic assessment of the Christians for philosophical reasons. ${ }^{206}$ I have argued that there were positive assessments already existing before Galen. Indeed, something similar was already present in the remarks and comments of both Epictetus and Marcus Aurelius. Even Lucian's satirical view lent some sympathy toward Christians. All of these accounts were far from the abhorrent reports of Tacitus, Suetonius, and Pliny. ${ }^{207}$ One characterization is common to all authors I have engaged with here: the contempt of death expressed by the Christians. However, there are also other features. Galen and Epictetus maintained that Christian conduct was quite praiseworthy. While Epictetus made this point by way of analogy - with Christians following rules as do the Stoics-Galen directly assumed that Christians followed philosophical principles. Another "pair" can be found in Epictetus' and Lucian's description of Christianity as a mystery cult, which seems to be due to the self-representation of Christians themselves.

All the pagan authors I have treated here saw Christians in one way or another in relation to philosophy. This is probably a mirror effect of the Christian self-representation. ${ }^{208}$ In pagan eyes, Christians were perplexingly situated between categories. Marcus Aurelius found them a place with the help of his military metaphor. On the one hand, it mapped the attributes of philosophers onto those of Christians, as the metaphor was often used to describe the philosophical stance. On the other hand, the metaphor showed that Christian steadfastness is not due to reasonable argumentation but rather training in obedience to commandments. For Galen, the Christians were a conundrum: while they could be counted among the philosophical schools, they were also common people with a belief in myths.

\footnotetext{
205 Hadot 2002.

206 Walzer 1949, 69.

207 Alexander (2002, 245-246) makes a similar contrast between Epictetus and Galen, on the one hand, and Tacitus and Pliny, on the other.

208 Wilken 1980, 109-110.
} 
It is understandable that the confusion created both sympathetic and hostile images of the Christians. John Granger Cook showed the Romans' shock in the face of the otherness of Christianity. ${ }^{209}$ It tells the other side of the story. Epictetus - as a contemporary of Tacitus, Suetonius, and Pliny-had a quite different tone when speaking of Christians. At the end of the second century, the dual views were still present. Fronto and Celsus represented the hostile front, while Lucian and especially Galen saw positive elements in Christianity: Lucian ridiculed Christian simplicity but not without a certain sympathy, while Galen saw that such simplicity was no hindrance to a conduct comparable to that of the true philosophers. The partially positive view of Christians among some pagan authors of the second century proves that the category of "other" was not always loaded with pure hostility. Although the gentile philosophers did not acknowledge Christians fully as their peers, they granted them a certain amount of recognition. There was certain positive value in Christianity. For their part, Christians clearly sought philosophical recognition, understanding philosophy as a positive category. Next, I wish to show that this pursuit of philosophical recognition was not merely a second-century phenomenon. It was apparent already in the first century.

Early Christians Seeking Recognition in Greco-Roman Culture

Tertullian, an early Christian theologian from around $200 \mathrm{CE}$, has won a place in history as a paradigmatic Christian character who misrecognized philosophy with his words "What indeed has Athens to do with Jerusalem?" (Praescr. 7; ANF 3.246). Since Athens represented philosophy and Jerusalem the Christian faith, the question deals with the relationship between faith and philosophy. Tertullian's question is rhetorical, as is evident from its textual context. The unstated answer is self-evidently: "They have nothing do with each other." One can speak of a blatant misrecognition of philosophy.

In this section, I question whether Tertullian really represented the standard Christian position. The philosophical assessments of Christians presented in the previous section would be incomprehensible if Christians had misrecognized philosophy in the uncompromising manner that Tertullian's statement seems to presume. Misrecognition is not the only available way of reading the dynamic - and this applies even in Tertullian's own writings. The later history of theology shows that philosophy was assimilated into the developing

209 Cook 2010, 2. See also Wagemakers' (2010) article on anti-Christian accusations of immoral sexual behavior and cannibalism. 
Christianity. Did this represent a fall from an original purity, and is Tertullian reacting to this later shift to philosophy, seeing it as a decline? My answer is in the negative. There was an interaction with philosophy from the earliest Christian sources onward.

However, Tertullian's misrecognition of philosophy gave voice to a lasting tradition. With his anti-philosophical ethos, Tertullian is not a unique case in the history of Western thought. One could list multiple names, but I will refer to just two cases after Tertullian, who exemplify the continuing tradition from antiquity until modern times: Martin Luther and Bertrand Russell. Luther states that Aristotle is a heathen who "has caught and made fools" (vorfuret und narret hat) of even the best of the Christians. In a nutshell: "Using him God has plagued us for our sins" (got hat uns also mit yhm plagt umb unser sund willen). Luther criticizes the use of Aristotle, whose understanding is limited, as the Holy Scriptures teach everything that is necessary. ${ }^{210}$ Bertrand Russell makes the same division as Luther, but preferring philosophy to Scripture: "A good world needs knowledge, kindliness, and courage; it does not need a regretful hankering after the past or a fettering of the free intelligence by the words uttered long ago by ignorant men. It needs a fearless outlook and a free intelligence."211

From ancient times to the present day, there seems to be a tradition of making a clear-cut separation between religion and philosophy. ${ }^{212}$ In line with this, Jerusalem and Athens withheld recognition from each other. The separation between religion and philosophy can be specified - at least from one important angle - as an opposition of free intellectual exploration and the Bible. Both Luther and Russell spoke of this contrast. One may respond that Tertullian, Luther, and Russell spoke within their own personal and existential spheres. I must note that this division between faith and philosophy is present also in academic work. Many scholars seem to put ancient texts more or less unconsciously into this matrix with the result that the division is seen everywhere. ${ }^{213}$ In academic work, we should get rid of this division and study the relationship between philosophy and religion in more general and nonsubjective terms. I take my examples of this division in academic work with an eye to my study and, therefore, I quote some classics on the relationship of Galen and Epictetus to the Christians.

210 WA 6.458. On Luther's attitude toward Aristotle, see, e.g., Dieter 2001.

211 Russell 1957, 23.

212 On the relationship between religion and philosophy, see, e.g., Ebeling 1962.

213 See Engberg-Pedersen 2001, 11. 
In his Galen on Jews and Christians, Richard Walzer reconstructs an opposition between faith and reason. The foundation is one sentence, where Galen criticizes "the followers of Moses and Christ" for accepting everything on faith (or trust). As I showed in the previous section, this saying does not blame faith ( $\pi$ i $\sigma \tau i \varsigma)$ as such. Yet, it is worth noting that Walzer constructs a philosophy/religion distinction on the basis of this statement. Walzer argues that the Greek intellectuals did not understand faith in terms similar to those of Philo or the Christians. ${ }^{214}$ As George van Kooten notes, the philological division characterized by the term $\pi$ i $\sigma \tau$ เ has the undesirable result "that early Christian sources have become disconnected from their natural habitat in the ancient world at large."215 He shows that there is no clear-cut distinction between the way the Christians and Plutarch used the word $\pi$ i $\sigma \tau \iota \zeta$. Van Kooten concludes: "Further comparative research into early Christian and ancient philosophical notions, values and virtues might show that, in many respects, they are more closely related than a modern, anachronistic understanding of the difference between philosophy and religion seems to allow."216

One should not limit van Kooten's view only to the interpretation of a single term. In contrast to the modern philosophy/religion distinction, ancient philosophers were quite religious. Philosophers spoke intimately of God(s) and composed hymns like the Hymn to Zeus by Cleanthes the Stoic. The adherents of a school were religiously committed to founder figures, whose divine nature was emphasized and whose texts were treated as authoritative. ${ }^{217}$ Anders Klostergaard Petersen has convincingly shown that Plato's philosophy is religion from our modern point of view. ${ }^{218}$ Many scholars have noted the tendency to adhere to authoritative texts in ancient philosophy. Here, the effort to maintain the difference between religion and philosophy can lead scholars into difficulties. In his Epiktet und das Neue Testament, Adolf Bonhöffer characterizes the difference between early Christianity and Stoicism by noting that, despite its religious traits, Stoicism was a philosophy based on reason and not on revelation. ${ }^{219}$ In the same book, however, he admits that Epictetus celebrated Zeno and Chrysippus in a similar fashion as Christians celebrated divine revelation: in a fixed moment of history, rational truth (Vernunftwahrheit) emerged through these founding figures. Is this so different from Christianity? When we

\footnotetext{
214 Walzer 1949, 48-56.

215 Van Kooten 2014, 216.

216 Van Kooten 2014, 233. For profound analysis of $\pi i \sigma \tau \iota \varsigma$, see also Morgan 2015.

217 Van Kooten 2010, 6-8. See also Alexander 2001.

218 Klostergaard Petersen 2017.

219 Bonhöffer 1911, 354.
} 
take a look at Bonhöffer's earlier book Die Ethik des Stoikers Epiktet, the picture of Epictetus' position becomes even more confusing:

Yes, he [Epictetus] also knows the concept of revelation: the writings of Chrysippus, whom he praises as the greatest benefactor of humankind, because through him the gods have shown the truth leading to happiness (Disc. 1.4.28, etc.). The writings also function for him in a sense like a sacred codex and ground both his teaching and homilies in the same way as the biblical texts do for Christian preaching. ${ }^{220}$

Bonhöffer's and Walzer's attempts to maintain the philosophy/religion distinction are dubious even in light of their own studies. Walzer admits that, at least socially, Christians resembled philosophers:

It would be natural, even had we no particular evidence, for Galen's contemporaries to mistake a religion of this unusual kind for a new philosophical school. For religious teachers who offered guidance in conduct and a scheme of the universe were so different from the priests of traditional Greek rites and cults that it is not at all astonishing that they should be looked on as philosophers. ${ }^{221}$

Loveday Alexander has put forth the same argument. The role of philosopher provided the Jews and the Christians with a template within the structures of imperial public life. Through the channels of philosophy these foreign groups could gain power, while philosophy also provided a culturally recognized arena for resistance. ${ }^{222}$ During recent years, several scholars have emphasized that the early Christians actually took part in the philosophical discourse. ${ }^{223}$ I showed above that the philosophical character of early Christianity is not only a modern reconstruction. Several second-century Roman philosophers

220 "Ja er kennt auch den Begriff der Offenbarung: die Schriften des Chrysipp, den er als den grössten Wohlthäter der Menscheit preist, weil durch ihn die Götter die zur Glückseligkeit führende Wahrheit gezeigt haben (I, 4, 28 etc.), gelten ihm gewissermassen auch als ein heiliger Kodex und bilden für seinen Unterricht und seine Homilieen in ähnlicher Weise die Grundlage wie die biblischen Texte für die christliche Predigt" (Bonhöffer 1896, 2; translated by myself and Lisa Muszynski, emphasis in the original).

221 Walzer 1949, 51.

222 Alexander 2002.

223 In addition to those mentioned above e.g., Engberg-Pedersen 2000; 2010; Huttunen 2009; van Kooten 2008; Thorsteinsson 2010; Wasserman 2008. The views naturally diverge in the details, but the general tendency is to see early Christianity in the philosophical context. 
acknowledged the philosophical cast of Christians. Next, I will show that these non-Christian accounts of Christians mirror Christian self-representation.

I concentrate on several New Testament texts often presented as a foundational justification for the misrecognition of philosophy: Colossians 2, Acts 17, and 1 Corinthians $1-2$. I argue that these texts actually make good use of the ancient philosophical discourse, so that one can read them as seeking recognition in the Greco-Roman intellectual milieu. I claim that the philosophical tendency was present already in the earliest extant Christian texts. After that, I will briefly present 1 Corinthians 7 as an example of philosophy. This case shows that philosophy was not taken up only in cases that marked the boundaries between its relationship with Christianity. Instead, I show that philosophical arguments are a natural part of Paul's argumentation. Thus, the later mutual recognition between Christians and philosophers had its necessary background in what the earliest Christians presented in their writings. This section makes comprehensible the partial recognition of Christianity from the side of pagan philosophers. I argue that this philosophical recognition was only a mirror of the Christians pursuing it. At the end of this section, I briefly discuss Justin Martyr as an example of the intellectual and philosophical development among the early Christians. In the following centuries, the intellectual spheres of society were Christianized, which helps to clarify the view that the religion/philosophy division is a biased way of construing history.

\subsection{Athens and Jerusalem - Still Something in Common}

Tertullian justifies his misrecognition of philosophy with two references to the Bible: Colossians 2:8 and Acts 17:17-18 (Praescr. 7; trans. ANF 3.246). These verses are the only ones in the entire New Testament to mention philosophy and philosophers. ${ }^{224}$ Colossians mentions philosophy:

See to it that no one takes you captive through philosophy ( $\delta \dot{\alpha} \tau \hat{\eta} \varsigma$ $\varphi(\lambda \circ \sigma \circ \varphi i \alpha \varsigma)$ and empty deceit, according to human tradition, according to the elemental spirits of the universe, and not according to Christ.

Col 2:8

224 In the Greek Old Testament (Septuagint), philosophers and philosophy are mentioned only in Dan 1:20 and several times in 4 Macc. According to Otto Michel $(1973,176)$, in 4 Macc 5 King Antiochus and the Jew Eleazar discuss whether Judaism can be recognized

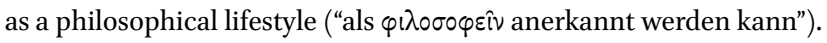


Tertullian emphasizes that Paul (or so Tertullian believes the author to be-the epistle's authorship is a controversial topic) ${ }^{225}$ explicitly names "philosophy as that which he would have us be on our guard against." The second biblical reference Tertullian uses is the story of Paul's visit to Athens:

So he argued ( $\left.\delta เ \varepsilon \lambda \varepsilon^{\gamma} \varepsilon \tau 0\right)$ in the synagogue with the Jews and the devout persons, and also in the marketplace every day with those who happened

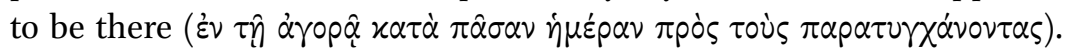

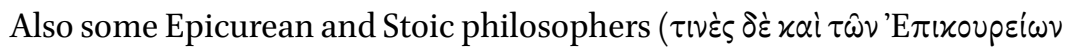
xai $\Sigma \tau \circ \ddot{x} x \omega v \varphi(\lambda \circ \sigma o ́ \varphi \omega \nu)$ debated with him. Some said, "What does this babbler want to say?" Others said, "He seems to be a proclaimer of foreign divinities ( $\xi \dot{\varepsilon} v \omega \nu \delta \alpha \mu \rho \nu i \omega \nu) . "$

Acts $17: 17-18$

On Paul, Tertullian notes: "He had been at Athens, and had in his interviews (with its philosophers) become acquainted with that human wisdom which pretends to know the truth, whilst it only corrupts it." As Acts mentions two different philosophical schools, the Epicureans and Stoics, Tertullian hastens to argue that philosophy is "divided into its own manifold heresies, by the variety of its mutually repugnant sects." Reflecting on Paul's visit to Athens actually leads Tertullian to the rhetorical question: "What indeed has Athens to do with Jerusalem?"

However, the implied negative answer is prescriptive, not descriptive. Tertullian means that Athens and Jerusalem should not have anything in common - but in fact they do have a lot in common. The context of Tertullian's attack on philosophy has a background in his attack on Christian theologians whose views he did not accept. He blamed them for heresies arising from blending faith and philosophy. "Away with all attempts to produce a mottled Christianity of Stoic, Platonic, and dialectic composition!" Tertullian exclaims. However, if blending philosophy and Christianity is a brand of heresy, Tertullian himself is heretical. It is widely known that his theology is deeply in debt to philosophy, especially Stoicism. The polemics against philosophy is in fact nothing but polemics against heresies. Outside this constellation, he

225 Most scholars assume that Colossians was written after Paul, despite the fact that the epistle presents itself as written by him. On the discussion, see standard scholarly commentaries on the epistle or, for example, Leppä 2003. 
can "call on the Stoics also to help" and then praise Zeno of Citium, Cleanthes, and Chrysippus (An. 5; trans. ANF 3.184-185). ${ }^{226}$

Tertullian's harsh criticism of philosophy seems to be an occasional rhetorical device rather than a conscious theological position. A careful reading also reveals that Tertullian's biblical references do not present an uncompromising position regarding philosophy. A few verses after condemning philosophy, the author of Colossians admonishes:

Do not let anyone condemn you in matters of food and drink or of observing festivals, new moons, or sabbaths. These are only a shadow ( $\sigma$ xid́) of what is to come, but the substance $(\sigma \hat{\omega} \mu \alpha)$ belongs to Christ.

Col 2:16-17

A philosophically trained reader may notice that here we encounter a variation of Plato's allegory of the cave (Resp. 514a-518b). Plato tells the story of people chained in a cave, where shadows on the walls present everything they know of the world outside. According to Plato, material facts are like the shadows of immaterial ideas. Colossians adapts the Platonic allegory to the apocalyptic, temporally oriented linear worldview. The true substance is to come, but its shadow is already visible in the present. Lacking this temporal dimension, Plato's allegory does not speak of the present and the future. Instead, the shadows and the ideas are present at the same time. Despite this difference, Colossians shares the contemporary philosophical discourse. ${ }^{227}$ The author of Colossians adapts the Platonic allegory to her or his own purposes: Jewish ritual practices are but a shadow of the substance, and ignorance in these matters should not lead to condemnation (hinting at a potential conflict with Jewish Christians). A conflict is also present in Plato's text. The philosopher who knows the ideas

is forced to plead in the law courts, or anywhere else, about the shadows $(\sigma \varkappa i \hat{\omega} v)$ of justice, or the images whose shadows ( $\sigma x i \alpha i)$ they are, and dispute about it on the basis of how these things are understood by those who have never yet seen actual justice.

Resp. 517d; trans. EMLYN-JONES and PREDDY, LCL

226 On Tertullian's slogan, its interpretation, and his use of philosophy, see, e.g., Osborn 1997, $27-47$.

227 Sometimes scholars note that the pair $\sigma \hat{\omega} \mu \alpha$ and $\sigma \varkappa \dot{\alpha}$ are unusual, as one usually speaks of

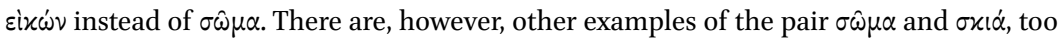
(see, e.g., O'Brien 1982, 139-140). Moreover, Plato does not use any fixed terminology for the substance in his allegory. 
Although the Platonic theory is modified into a Jewish-Christian dialogue, its philosophical source can still be felt. Does this use of philosophy go directly against the condemnation of philosophy only some verses earlier in the same text? It may well be that the condemnation is a rhetorical move, just as we saw in Tertullian's case. The other-and more probable - explanation is that the rejection of philosophy by the author of Colossians does not involve general condemnation. Scholars usually note that the author is speaking of her or his adversaries and, thus, of their particular philosophy. ${ }^{228}$ As the adversaries seem to be obliged to adhere to some Jewish ritual practices, it may seem extraordinary to call their views "philosophy." Yet, we have several examples of Judaism or some of its sects presented in that way. ${ }^{229}$ This wide understanding of philosophy is by no means limited to Judaism. In fact, the separation between religion and philosophy is extraordinary in ancient culture. According to Pierre Hadot, even Epicureans who denied vernacular beliefs participated in the cult.

In antiquity, the philosopher encountered religion in his social life (in the form of the official cult) and in his cultural life (in the forms of art and of literature), yet he lived religion philosophically by transforming it into philosophy. If Epicurus recommended participation in civic festivals and even prayer, this was to allow the Epicurean philosopher to contemplate the gods as conceived by the Epicurean theory of nature.... The philosophical way of life never entered into competition with religion in antiquity, because at the time religion was not a way of life which included all of existence and all of inner life, as it was in Christianity.230

This philosophical attitude toward religion is present also in the philosophy which the author of Colossians opposes. Gregory E. Sterling notes how the Colossian philosophy coheres with the philosophical views of the Hellenistic Jewish philosopher Philo of Alexandria, who in turn owes much to the Middle Platonic demonology. Sterling supposes that the author of Colossians seemingly knew the Middle Platonic scale of being. Sterling says:

The scale they knew placed the angels or daemons in the intermediate zones between God and humanity. Their fasting practices suggest that

228 Michel 1973, 183-184; Bormann 2012, 126.

229 O'Brien 1982, 109; Bormann 2012, 127.

230 Hadot 2002, 271-272. See Maisch 2003, 153: "Philosophie bezeichnet im Hellenismus nicht ein theoretisches Lehrgebäude, sondern ein umfassendes System, das Weltdeutung, Identitätsstiftung, Spiritualität, Einsicht in den rechten Lebensvollzug und sogar magische Praktiken in sich vereinigt." 
they thought of these beings negatively: their asceticism served as a protection against injurious elemental spirits. It is likely that they observed their fasts in conjunction with a Jewish liturgical calendar. ${ }^{231}$

The Colossian philosophy is what Hadot describes as practicing religious rites with a philosophical mindset. The author of the epistle philosophically responds to this practice by placing such rites in the lower level of shadows. It remains unclear if this is a carefully considered answer to the scale of being. The scale cannot explain the temporal dimension introduced by the author, but this difficulty should not be overestimated. Hebrews (8:5; 10:1) contains temporal and non-temporal adaptations of the Platonic allegory, side by side. The discrepancy between the eschatological and non-eschatological adaptations, however, is not enough to dismiss philosophical influences in Colossians. Both the author of Colossians and her or his adversaries seem to participate in a discussion which one can describe as being philosophical in nature.

The case of Acts is clearer. One cannot avoid noticing that its relationship with philosophy is much more positive than Tertullian claims. Actually, Paul's figure in the narrative hints at Socrates. ${ }^{232}$ David M. Reis has called Acts 17 an echo chamber, which not only provides an opportunity to hear Socratic reverberations in the figure of Paul, but also Pauline echoes in the figure of Socrates. Justin Martyr invoked the latter when describing Socrates as Paul at the Areopagus (2 Apol. 10). ${ }^{233}$ With the help of the Socratic echoes, the Areopagus episode positions Christian identity within the Greco-Roman intellectual culture and thus sets a standard for the recognition that Christians sought among the philosophers.

The author of Acts ${ }^{234}$ opens the episode by narrating Paul's sightseeing in Athens. The apostle roams in public every day, arguing ( $\delta \varepsilon \lambda \varepsilon \dot{\varepsilon} \gamma \tau 0)$ in the synagogue and in the marketplace ( $\dot{\varepsilon} \nu \tau \hat{\eta} \dot{\alpha} \gamma o p \hat{\alpha})$ with "those who happen to be there." This is what Socrates did:

Socrates lived ever in the open; for early in the morning he went to the public promenades and training grounds; in the forenoon he was seen in the market ( $\dot{\alpha} \gamma o p \hat{\alpha} s)$; and the rest of the day he passed just where most people were to be met: he was generally talking, and anyone might listen.

Xenophon, Mem. 1.1.10; trans. MARCHANT, LCL

\footnotetext{
231 Sterling 1998, 270.

232 This observation is commonplace among scholars. See Sandnes 1993, 20.

233 Reis 2002, 26o, 273-274.

234 In fact, we do not know the name of the author who is responsible for Acts and the gospel bearing Luke's name. The scholarly commentaries discuss the question of authorship.
} 
I have never been anyone's teacher, but if anyone, young or old, is keen to hear me speak and getting on with my activities, I have never begrudged

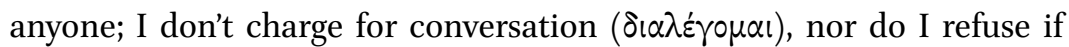
no money is offered, but I make myself available to rich and poor alike for questioning as well as if anyone wants to hear and give an answer to whatever I have to say.

Plato, Apol. 33a; trans. EMLYN-JONES and PREDDY, LCL

Paul is reproached for being a proclaimer of foreign divinities ( $\xi \varepsilon v \omega \nu \delta \alpha \mu \nu v^{\prime} \omega \nu$ ) and Socrates for proclaiming novel divinities ( $\varkappa$ alvà $\delta \alpha \iota \mu o ́ v i \alpha)$ (Xenophon, Mem. 1.1.1; Plato, Apol. 24c). When the story continues in Acts, Paul is taken to the Areopagus to report his teaching (Acts 17:19). Again, Luke's choice of words echoes the story of Socrates, who was sentenced to death there. In Paul's time, the Areopagus possibly functioned as a city council, ${ }^{235}$ but this is a moot point. The name Areopagus in the story merely serves to create a new echo of Socrates. Even Luke's ambiguous word choice is evocative. The verb $\dot{\varepsilon} \pi i \lambda \alpha \mu \beta \alpha$ 'vo $\mu \alpha \iota$ may mean 'arrest' but also well-intentioned attachment. ${ }^{236}$ Luke "appears simply to evoke the image of trial and arrest, allowing it to resonate in the reader's mind without feeling the need to make the connection explicit."237 Furthermore, both Socrates and Paul began their speeches at the Areopagus

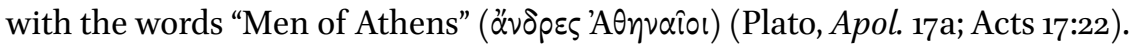

As a result, one can easily agree with Sandnes' observation that there is "a firm basis for saying that the prelude to the Areopagus speech involves a clear comparison between Paul and Socrates." Sandnes emphasizes that readers were aware of this comparison, since Socrates' figure was well known. Sandnes cites Lucian's words to illustrate the situation: "His praises are sung by everyone" (Gall. 12 ). ${ }^{238}$ Socrates' reputation was impeccable among the majority of the educated, but some did not praise him. Scholars have mainly missed that Luke uses the Socratic echoes to locate Paul more closely with one of the two previously mentioned philosophical schools: namely, closer to the Stoics than to the Epicureans. The Stoics eagerly invoked Socrates, while the Epicureans despised him. According to A. A. Long, "from Zeno to Epictetus, that is to say throughout the history of the Stoa, Socrates is the philosopher with whom the Stoics most closely aligned themselves." Three stories of Zeno, who founded the Stoic school, tell of his devotion to philosophy, pointing out that Socrates inspired him in one way or another. Long accurately notes the function of

\footnotetext{
235 Barrett 2004, 831-832.

236 Barrett 2004, 831.

237 Reis 2002, 270-271.

238 Sandnes 1993, 22. Similarly many others; see, e.g., Alexander 2002, 230.
} 
these diverging accounts: "The literal truth of these stories is unimportant. What they attest to is a tradition, which Zeno's followers must have encouraged, that Socrates was the primary inspiration of his philosophy." One source even claims that the Stoics wanted to be called Socratics. ${ }^{239}$ The contrary was true of the Epicureans:

If Epicurus was fairly restrained in his remarks about Socrates, his immediate followers were not. From Metrodorus and Idomeneus, extending through Zeno of Sidon and Philodemus down to Diogenes of Oenoanda, a tradition of hostility to Socrates was established that is virulent even by the standards of ancient polemic. In their writings, Socrates was portrayed as the complete anti-Epicurean - a sophist, a rhetorician, a sceptic, and someone whose ethical inquiries turn human life into chaos. ${ }^{240}$

Thus, Paul's Socratic characterization associates the apostle with the Stoics. This association becomes clearer in the speech that Luke has him deliver at the Areopagus. Of the several Stoic themes of the speech, ${ }^{241}$ it is enough to men-

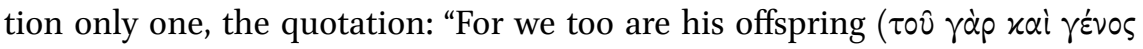
$\left.\dot{\varepsilon} \sigma \mu \varepsilon^{\prime} v\right)$ " (Acts 17:28). These words belong to the opening verses of the poem Phaenomena by the Stoic Aratus:

From Zeus let us begin; him do we mortals never leave unnamed; full of Zeus are all the streets and all the market-places of men; full is the sea and the havens thereof; always we all have need of Zeus. For we are also

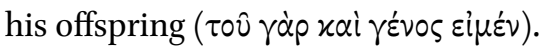

Aratus, Phaen. 1-5; trans. MAIR and MAIR, LCL

Aratus' poem was famous and celebrated in antiquity. Its reputation is illustrated by the fact that the poem was translated several times into Latin (for example, by Cicero and Ovid). ${ }^{242}$ The Jew Aristobulus of Alexandria cited it in the 2nd century вСЕ, which shows that the poem was also known within the Jewish sphere (Eusebius, Praep. ev. 13.12.1-8). Aratus' Stoic idea of God permeating the whole universe accords well with Paul's Areopagus speech, in which

\footnotetext{
239 Long 1988, 151, 16o-161. Long $(1988,150)$ also states: 'Socrates' presence in Epictetus' Discourses - which I must pass over here-could be the topic of a monograph." This task was completed in 2002 in his book Epictetus: A Stoic and Socratic Guide to Life.

240 Long 1988, 155 .

241 Scholars routinely note the Stoic coloring of the speech. See, e.g., Barrett 2004. This does not exclude, however, the possibility of also finding parallels with the Jewish texts.

242 Fantuzzi 1996, 959-96o.
} 
he preaches: "In him [i.e., God] we live and move and have our being" (Acts 17:28). However, at the end of his speech Paul diverges from the Stoics by saying that God has overlooked ignorance until now (Acts 17:30). This is an implicit placing of the Stoics among other ignorant people. The sudden turn of the speech after a Stoic-sounding proclamation is a slap in the face of the Stoics, who claimed to know the truth and - contrary to the Sceptics—claimed that virtue is nothing other than knowledge. ${ }^{243}$ The Stoics associated their teaching with Socrates, but the Socrates figure here nullifies their knowledge. In a way, Paul fulfills Socrates' prophecy: "you'd spend the rest of your lives asleep, unless the god were to send you someone else, in his care for you" (Plato, Apol. 31a; trans. Emlyn-Jones and Preddy, LCL). ${ }^{244}$ Paul is the prophesied person in Luke's narration, the real follower of Socrates.

From the perspective of seeking recognition, the Areopagus episode is interesting. Paul debates with the philosophers with the consequence that he is challenged to report his teaching at the Areopagus. It is as if the Athenians were considering their recognition of Paul. Paul, in turn, seeks recognition by adhering to the Stoics in his speech. At the end of the speech, the constellation turns upside down: Paul proclaims that everything up to that point has been ignorance. The apostle assumes the role of granting or withholding recognition - in this case the latter. The audience becomes irritated with Paul's idea of resurrection. They seemingly interrupt the speech and, in turn, withhold their recognition. Only a small group joins Paul, like those who remained faithful to Socrates during his trial (Plato, Apol. 38b; Xenophon, Apol. 27-28). The mutual misrecognition, however, is not the whole story. In the eyes of the reader, through the character of Paul Christianity attains its place among the philosophical schools. Ries comments aptly:

Luke constructs a Socratic Paul who deftly negotiates among his enemies with rhetorical skill, first by developing an argument for reality of the one true God based on common Hellenistic philosophical principles, and then by proclaiming the decidedly Christian teaching about the resurrection and judgment, which elicits among his audience consternation, intrigue, and conversion. ${ }^{245}$

\footnotetext{
243 Long $1988,158$.

244 One may note that the idea of a prophecy did not sound strange to Stoic ears. The Stoics firmly believed in divination, and Cicero relates that the Stoic Antipater "gathered a mass of remarkable premonitions received by Socrates" (Div. 1.123; trans. Falconer, LCL).

245 Ries 2002, 272-273.
} 
Paradoxically, the fact that the encounter with philosophers at the Areopagus terminates in mutual misrecognition may be the ultimate catalyst for locating Christianity among the philosophers. Hubert Cancik notes that the recurrent disputes in Acts elevated Christianity from a cult to a philosophical school:

It is furthermore highly remarkable, so far as I see, that this kind of dispute over unity, inheritance, and continuity does not occur in Greek and Roman religion. Controversies over "worldview," moral behavior, the relation of the individual to the state, marriage, work, war, and death, so far as these can be rationalized, are dealt with in Greco-Roman culture by means of philosophy, not religion. ${ }^{246}$

Luke's picture of Paul disputing with philosophers did not propagate an anti-philosophical tendency. The episode is rather a claim of Christianity as the most truthful philosophy, which surpasses other schools. Tertullian's anti-philosophical reading of this text seems more than questionable. I will still widen the discussion on the first two chapters of 1 Corinthians, which Tertullian did not use, but which are often thought of as representing an antiphilosophical attitude.

\subsection{Paul, Philosophy and the Torah}

\subsubsection{Corinthians-Philosophical Folly in the World}

"Has not God made foolish the wisdom of the world?" Paul ${ }^{247}$ asks rhetorically (1 Cor 1:20). Paul answers in the affirmative, as he also points out several times in 1 Corinthians 1-2. After the salutation, Paul briefly relates what he has heard of the Corinthians and then, from 1:18 onwards, proceeds to his criticism of worldly wisdom: The Greeks have searched for wisdom without acknowledging God. Therefore, God decided to save the world through foolishness ( $\mu \omega$ pi $^{\prime} \alpha$ ), through the proclamation of Christ crucified. Paul stresses that he did not proclaim this "in lofty words or wisdom" (2:1). He even denies knowing something,

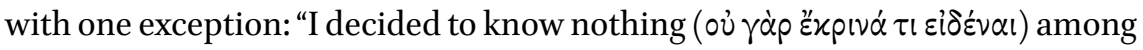
you except Jesus Christ, and him crucified" (2:2). Yet, Paul's proclamation is wisdom nonetheless: not "a wisdom of this age" (2:6), but God's wisdom so that "faith might rest not on human wisdom but on the power of God ( $\dot{\varepsilon} \nu \delta v v \alpha \dot{\alpha} \mu \varepsilon$ $\theta \varepsilon \circ \hat{v})$ " (2:5). Christians, he says, speak "in words not taught by human wisdom but taught by the Spirit."

246 Cancik 1997, 693.

247 Contrary to Colossians, the authorship of 1 Corinthians is not disputed. The author is Paul himself. 
In his commentary, Gordon D. Fee summarizes the main thesis of 1 Corinthians 1-2: "The gospel is not some new sophia (wisdom, or philosophy), not even a new divine sophia. For sophia allows for human judgments or evaluations of God's activity." ${ }^{248}$ What is this but a total misrecognition of philosophy? Loveday Alexander plainly speaks of an "apparently anti-philosophical stance adopted by Paul himself in the letter of Corinthians." ${ }^{249}$ Should Tertullian refer to this text? No. When Paul's words are placed in a philosophical context, they no longer seem so anti-philosophical. My aim is to show that there are several contact points with philosophy and that Paul's text therefore participates in philosophical discourse. I mostly cite Plato, but this does not indicate Paul's particular attachment to Platonism. Plato's texts were also used outside the Platonic school and interpreted differently by various schools. ${ }^{250}$ Instead of trying to link Paul to a certain philosophical school, ${ }^{251}$ I generally argue that the ostensibly anti-philosophical words themselves belong to the philosophical discourse.

Fee's claim that the gospel is no divine sophia is forced. In fact, he later has to admit that Paul speaks of divine wisdom in opposition to human wisdom. Fee explains that Paul "transformed 'wisdom' from a philosophical, rhetorical term into a historical, soteriological one."252 True, Paul identified salvific wisdom with the crucified Christ; thus, divine wisdom really is historical and soteriological. I argue, however, that these features do not rule out philosophy. One can find a similar opposition between human and divine wisdom in Plato's texts. In the Apology, Socrates states that Apollo called him the wisest human being. Socrates wanted to prove this claim wrong-without success. Socrates explains: "the god is in truth wise and this is what he means in this

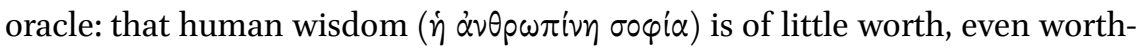
less." (Plato, Apol. 23a; trans. Emlyn-Jones and Preddy, LCL). Here the most famous representative of ancient philosophy differentiates between divine and human wisdom.

Plato's Sophist repeats the same opposition, adapting it to the division between the philosophers and the sophists. The latter imitates the former and, therefore, what the sophists represent does not belong to the divine, but

\footnotetext{
248 Fee 1987, 68, 98.

249 Alexander 2002, 230.

250 Long 1988, 152. For example, Long $(2002,70)$ suggests that the Stoic Epictetus "knew the Gorgias more or less by heart."

251 Some have seen similarities between Paul and the Stoics (e.g., Engberg-Pedersen 2000; 2010; Huttunen 2009; Thorsteinsson 2010), others between Paul and the Platonists (e.g., van Kooten 2008; Wasserman 2008). Downing (1998) prefers the Cynic Paul.

252 Fee 1987, 73 .
} 
to the human (ov $\theta \varepsilon \hat{0} 0 v \dot{\alpha} \lambda \lambda^{\prime} \alpha \dot{\alpha} \theta \omega \omega \pi$ ixòv) category (Plato, Soph. $268 \mathrm{c}-\mathrm{d}$ ). The background is Plato's theory of ideas: unlike the true philosophers, the sophists just imitate the divine wisdom of ideas. As imitators, the sophists remain on the worldly level. In 1 Corinthians, Paul does not represent the Platonic theory of ideas. Nevertheless, the opposition between human and divine wisdom is present in both Plato's and Paul's texts. This similarity is quite general, but it proves that the differentiation between divine and human wisdom created by Paul should not be straightforwardly explained as anti-philosophical.

Plato's dialogue $\operatorname{Ion}^{253}$ comes closer to Paul, who associates divine wisdom with the power of God. Meeting Ion, who is specialized in performing Homer's poetry, we are told that he is not at all interested in other poets and cannot even form any clear opinions about them. Socrates infers that Ion is not actually skilled in the art of poetry, for if he were, he would have been able to perform any work of it. As this is not the case, the conclusion is that Ion's skill to perform poetry - or anyone's, for that matter-cannot be of human origin. The skill must originate via divine influence, that is, divine power.

For not by art do they utter these things, but by divine influence ( $\theta \varepsilon i \alpha$

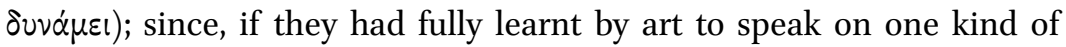
theme, they would know how to speak on all. And for this reason God takes away the mind of these men and uses them as his ministers, just as he does soothsayers and godly seers, in order that we who hear them may know that it is not they who utter these words of great price, when they are out of their wits, but that it is God himself who speaks and addresses us through them.

Plato, Ion 534c-d; trans. FOWLER and LAMB, LCL

One may recall that in the Republic, Plato openly expresses his disgust of poetry, which is just an imitation of reality: "Starting with Homer, all composers of poetry are imitators of images of virtue and of every other subject they deal with, but they don't grasp the truth" (Resp. 6ooe; trans. Emlyn-Jones and Preddy, LCL). Thus, poetry as an imitation is on the level of sophistic arguments. It is thus possible, though not obvious, that Plato's praise of divine inspiration in Ion is ironic; in reality, Plato might be hinting that poetry is nothing but foolishness. ${ }^{254}$ Be that as it may, Plato is not the only philosopher to present the concept of divine power. In Xenophon's version of Socrates' Apology,

253 It is possible that Ion was not written by Plato himself, but somewhat after him (Thesleff 1982, 221-223).

254 Thesleff 1982, 222. 
Socrates says that the daimonion speaking to him is no novel idea, as people traditionally believe in omens coming through birds, thunder, and the Pythia.

The only difference between them and me is that whereas they call the sources of their forewarning 'birds,' 'utterances,' 'chance meetings,'

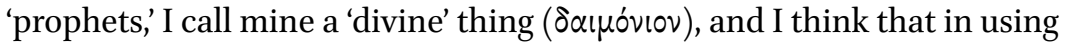
such a term I am speaking with greater truth and piety than those who

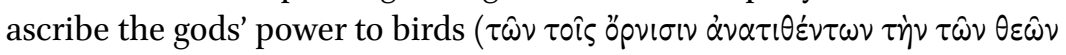

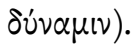

Xenophon, Apol. 13; trans. MARCHANT, LCL

A later philosopher presenting the idea of divine power can be found in the text of the Stoic Epictetus at the beginning of the 2nd century CE. Epictetus may be basing himself on Xenophon's words, as his argumentation is quite similar. ${ }^{255}$ Epictetus creates an opposition between the divine message and the human message, with the former originating in divine power.

Once you have heard these words go away and say to yourself, "It was not Epictetus who said these things to me; why, how could they have occurred to him? but it was some kindly god or other speaking through him. For it would not have occurred to Epictetus to say these things, because he is not in the habit of speaking to anyone. Come then, let us obey God, that we rest not under His wrath." Nay, but if a raven gives you a sign by his croaking, it is not the raven that gives the sign, but God through the raven; whereas if He gives you a sign through a human voice, will you pretend that it is the man who is saying these things to you, so that you may

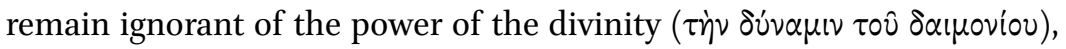
that He gives signs to some men in this way, and to others in that, but that in the greatest and most sovereign matters He gives His sign through His

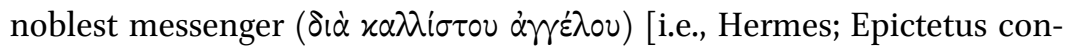
tinues by citing the Odyssey]?

Epictetus, Disc. 3.1.36-37; trans. Oldfather, LCL

Epictetus does not seriously claim to be an oracle in the normal sense of the word. ${ }^{256}$ However, he surely understood his philosophical message as divine wisdom, which makes the comparison to oracles understandable. As a Stoic,

255 Long $(1988,151)$ holds it as certain that "Epictetus has reflected hard on the Socratic writings of Plato and Xenophon."

256 Huttunen 2009, 21. 
Epictetus believed in the god within, which he calls by many names. Here he speaks of the power of $\delta$ alpoviov, which denotes the divine and the rational part of the human being. ${ }^{257}$ Thus, "the power of the divinity" simply means human rationality. This is not what Paul thinks. ${ }^{258}$ However, his concept of the divine Spirit abiding within Christians comes close. He makes it clear that the Spirit boosts cognitive capacity (1 Cor. 2:10-16). ${ }^{259}$ Stoics could also call the divinity 'spirit' ( $\pi v \varepsilon \tilde{\mu} \mu \alpha)$, though the word is quite rare in Epictetus' usage. ${ }^{260}$

Finally, I would like to treat Paul's report of his earlier sojourn, found in 1 Corinthians: "I did not come proclaiming the mystery of God to you in lofty

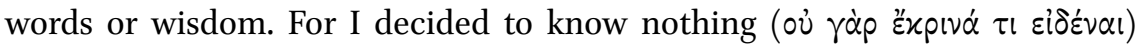
among you except Jesus Christ, and him crucified" (1 Cor. 2:1-2). ${ }^{261}$ Fee understands this non-knowing as a rejection of philosophical reasoning, ${ }^{262}$ but even this saying has its parallel in Plato's Apology (21b,d; trans. Emlyn-Jones and Preddy, LCL): "I assure you I'm conscious that I'm not wise in any way great or small," and "It's probable, of course, that neither of us knows anything that is fine and good, but this man thinks he knows something without knowing it, whereas I, just as I don't know, I don't think I do either. At least it seems I'm wiser than this man in just this one minor respect, that I don't even think I

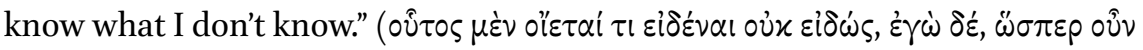

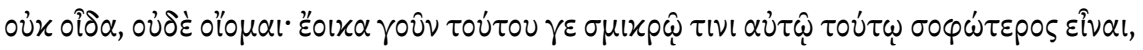

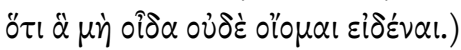

This sounds similar to Paul. ${ }^{263}$ Both Socrates and Paul reflect on their knowledge and make decisions accordingly. Paul does not claim to be ignorant, however, but reports about his decision to be ignorant except in what comes to Christ. Anthony A. Thiselton is right when he states that this interpretation releases Paul from any anti-intellectualism. ${ }^{264}$ Yet, if ignorance is

257 Bonhöffer 189o, 83-86. Bonhöffer's work is still worth consulting, despite its age. He profoundly contextualizes the philosophical concepts that Epictetus uses.

258 In Romans, there is a closer parallel to Epictetus. Paul presents the devotion to the rational cult ( $\tau \dot{\eta} \nu \lambda o \gamma(x \dot{\nu} \nu \lambda \alpha \tau \rho \varepsilon i \alpha \nu$ ) as an ideal (Rom. 12:1), similarly to Epictetus (Disc. 1.6.20).

259 On the cognitive role of the Spirit and its relationship to Stoicism, see Engberg-Pedersen 2010, $76-8$ o.

$260 \quad$ SVF 1.121.6; 2.112.31; 2.299.11; 2.306.21; 2.307.21. In Epictetus' texts, the word $\pi v \varepsilon \hat{u} \mu \alpha$ or its derivatives occur only in Disc. $2.1 .17 ; 2.23 .3 ; 3.3 .22 ; 3.13 .15$.

261 Paul's word order is somewhat surprising. The more precise translation may be "I did not decide to know something ..." However, I do not see any difference in the meaning. On the translation, see Thiselton 2000, 211-212.

262 Fee 1987, 92.

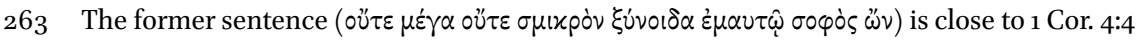

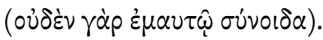

264 Thiselton 2000, 212. 
anti-intellectualism, is Socrates anti-intellectual? It depends on the philosophical school. As it turns out, the Sceptic school "invented" the Socrates who knows nothing. Conversely, the Stoic Socrates knows a lot of things. ${ }^{265}$ It is difficult to say what Paul's position on these epistemological questions was-if he even had strong attachments to any position. It is possible, however, that his words echo these discussions. In any case, the contemporary philosophical discussions prove that Paul's words are in no self-evident way directed against philosophy.

In sum, it seems plausible that Paul was partaking in the general philosophical discourse. The division between worldly and divine wisdom is present in the philosophical texts. Plato, Xenophon, and Epictetus refer to divine power. Although Paul emphasized his ignorance (except in matters of Christ), he does not seem to reject knowledge - and if he did, he would come close to the Sceptic school. These similarities do not diminish the dissimilarities. For example, Paul and Epictetus share a conviction regarding the divine power within human beings, but Paul restricts it to Christians, who are the only ones to receive the divine Spirit (1 Cor. 2:12). Stoics thought spirit to be present in every human being. Dissimilarities between Paul and Epictetus are clear, but there are also dissimilarities, say, between Plato and Epictetus. I cannot see that Paul's discourse categorically deviates from the philosophical discourse.

This being the case, I would like to question the traditional reading of 1 Corinthians 1 and 2. Paul does not try to deviate from philosophy, and he is not presenting a categorical alternative to what is earlier presented in philosophy. Quite the contrary, he joins in the contemporary philosophical discourse. In fact, Paul's words against specious human wisdom can be seen as a search for recognition in the intellectual culture of the day. In this discourse, truth was presented as a divine essence, opposite to that of worldly wisdom. Paul presents himself as the most truthful philosopher, a messenger by divine call ( $\chi \lambda \eta \tau \dot{\jmath} \varsigma \dot{\alpha} \pi \dot{\sigma} \sigma \tau \Delta \lambda \circ \varsigma)$ (1 Cor. 1:1), who reliably presents the divine mysteries, “God's wisdom, secret and hidden" (1 Cor. 2:7). Paul's revelatory character or invocation of the authority of the Septuagint do not make him a deviant either. As Pierre Hadot points out, in many philosophical schools of the imperial period, natural revelation "was augmented by what the Greeks have always believed: revelations made by gods to a few inspired mortals." The texts of Plato, Xenophon, and Epictetus quoted above exemplify this well. Hadot notes, "Also sought-after were revelations made to the barbarians: Jews, Egyptians, Assyrians, and inhabitants of India." Philosophical teaching took the form of

265 On the Sceptic and Stoic interpretations of Socrates, see Long 1988, 156-16o. 
commenting on authoritative texts. ${ }^{266}$ In this tradition, 1 Corinthians $1-2$ is not a misrecognition of philosophy.

But am I forgetting Paul's Judaism? If we look at his epistles, they are full of biblical citations and allusions. Equally clear references to philosophical authors are non-existent. Admittedly, Paul did not discuss philosophers in his epistles. Still, I maintain that his thoughts can be read within the context of philosophical discourse. The similarities are sufficiently recognizable. Next, I will support my claim by a short analysis of Paul's thoughts on law, which are routinely associated with the Torah. This is mostly right, but does not rule out the use of philosophy. If philosophy and the Torah were impossible bedfellows, Philo's Jewish philosophy should be an impossibility - which it is evidently not. We can expect that Paul could likewise combine the Torah and philosophical discourse.

\subsubsection{Paul's Philosophical Interpretation of the Torah}

It is well known that Jews in diaspora interpreted the Torah in terms of philosophical categories. ${ }^{267}$ Anyone can acknowledge this fact when reading, say, Philo's treatises where the Torah, as anything else, is interpreted in philosophical categories. Paul in this respect was surely not an exception among diaspora Jews. It is quite natural that Greco-Roman interpretations were not alien to the apostle, whose liberal views of gentile inclusion tested the boundaries of Judaism. It is also worth noting that the Greek expressions for "law," "commandment," "ordinance," etc. do not necessarily refer to the Torah. When Paul uses these, he does not necessarily mean the Torah and its regulations. Heikki Räisänen has shown that in some cases it is difficult to interpret ó vónos as the Torah. ${ }^{268}$

It is misleading, however, to track whether Paul is speaking of the Jewish law or law in Greco-Roman terms. As it is invariably a question of the same Greek terms, some strict dividing line is hard or even impossible to make. This is to follow the program of Troels Engberg-Pedersen, who demanded an end to using "any form of the Judaism/Hellenism divide as an interpretive lens." One should stop reading the comparative material "as if either the Jewish or the Hellenistic material is in the end the really important one." 269 The purpose is not to abandon Judaism or Greco-Roman categories, but to stop seeing them as mutually exclusive categories. If these categories can overlap in Philo, why

266 Hadot 2002, 149-153.

267 See, e.g., Weber 2000.

268 Räisänen 1992, 48-94.

269 Engberg-Pedersen 2001, 3-4. 
would they not overlap in Paul? Here my aim is to see how philosophical and Jewish elements overlap in one passage, 1 Corinthians 7:17-24. I make my point by comparing Paul's words to Epictetus' sayings. This is not to claim any direct dependence but to illustrate that Paul's words on the law and commands do not exclude philosophy.

As Paul was a diaspora Jew, it might seem reasonable to compare his views with those of other diaspora Jews, especially with those who have philosophical inclinations, such as Philo. However, I avoid this kind of comparison for methodological reasons. A comparison with diaspora Jews would lead to asking whether the similarities between potentially compared parts merely proves Paul's Jewishness. If Paul and another diaspora Jew were to present similar views, the easiest interpretation for the similarities would be their shared Jewish—not Greco-Roman-background. This would lead to again falling back on the Judaism/Hellenism divide. Therefore, I preclude the problem by comparing the views of Paul and a pagan thinker. In this comparison we see how much Paul resembles the latter's philosophical context, even when speaking of the law and commandments.

My procedure is as follows. First, I take a short look at 1 Corinthians 7:17-24 to illustrate the basic problem in Paul's statements on the commandments. Second, I present relevant passages in Epictetus' texts so that we can, third, turn back to Paul with the information gathered from Epictetus. I would like to show that Paul's thinking is heavily indebted to ideas that are similar to those of Epictetus. I do not hesitate to call Paul's thinking in 1 Corinthians 7:17-24 "Christian Stoicism." In this regard, Paul's Jewish and philosophical elements do not exclude each other.

In 1 Corinthians 7:17-24, Paul admonishes Christians to stay in their present social position and make use of it. Circumcision and uncircumcision are

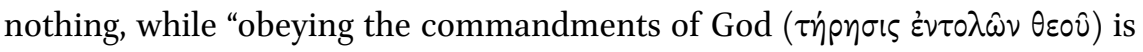
everything" (1 Cor 7:19). The expression has solid parallels in the Jewish literature. The Wisdom of Solomon states: "The beginning of wisdom is the most sincere desire for instruction, and concern for instruction is love of her, and

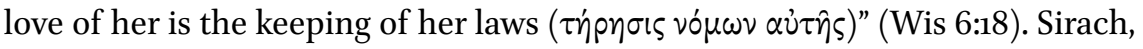
in turn, admonishes: "Guard yourself in every act, for this is the keeping of

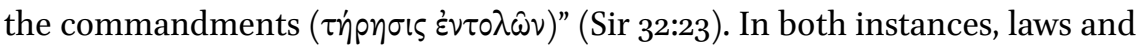
commands denote the Torah. ${ }^{270}$ Initially it makes sense to think that Paul also speaks of the commandments in the Torah. However, in closer analysis this interpretation becomes dubious. If Paul is thinking of the Torah, how could

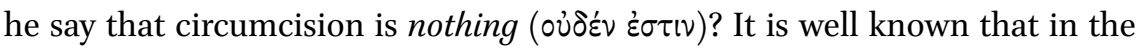

270 Lang 1986, 96; Räisänen 1987, 68. 
contemporary Judaism of the day, circumcision was held as one of the main expressions of obedience to the Torah.

Philo tells of so-called allegorists, who made a spiritual reinterpretation of the circumcision command (Philo, Migr. 89-93). Was Paul spiritualizing the circumcision? Had he meant this, circumcision would not be nothing but something, namely something spiritual, for example, similar to the circumcision of the heart in Romans 2:28-29. This, however, is not the case in 1 Corinthians 7:19, where circumcision is simply nothing. Another option is to interpret the commandments so that they refer to the love command (Lev 19:18). In Romans and in Galatians, Paul compresses the Torah to the love command (Rom 13:9; Gal. 5:14), but even this interpretation seems to be false. It is difficult to think that a plural "commandments" would refer to the one command. ${ }^{271}$ There is even a further difficulty, as love is not mentioned in the context. Neither the spiritualization nor the love command provides an interpretive option.

The meaning of the commandments must be primarily and closely examined in the textual context. In the larger passage (1 Cor 7:17-24), Paul discusses social positions. Therefore, the "commandments" probably have something to do with them. Many scholars have noted resemblances between Stoicism and Paul's teachings on social positions. In his Epiktet und das Neue Testament, Adolf Bonhöffer states: "There is no doubt that here exists one of the most important similarities between Stoicism and Christianity."272 Next I look at how Epictetus deals with social positions and how this theme sheds light on "the commandments of God" in Paul's text. I start quite far, in order to adequately place Epictetus' individual sayings on social positions within his larger philosophical system. In this way one can be sure that the similarities concern the contents and not only the wording. ${ }^{273}$

The nucleus of Epictetus' philosophy is the right division of things and the moral value or the lack of value. The division is aptly summarized in the opening section of Epictetus' Encheiridion. ${ }^{274}$ It begins with the fundamental division between the things, which are our own and under our control, and the things which are not our own $\left(\tau \dot{\alpha} \dot{\alpha} \lambda \hat{\lambda}^{\prime} \tau p / \alpha\right)$ and not under our control.

271 Lindemann 2000, 171.

272 Bonhöffer 1911, 171. See also, e.g., Jones 1987, 37, 53; Vollenweider 1989, 211, 241; Deming 1995, 159; Dautzenberg 2001, 61-62.

273 On the methodological considerations, see Huttunen 2009, 10-19.

274 The author of Encheiridion is not Epictetus but his student Arrian, who has summarized the main points of Epictetus' philosophy. On Encheiridion, see Brandt 2015. For Epictetus' philosophy in general, see Long 2002 and Bonhöffer 1890 and 1894. Bonhöffer's studies are still held in high regard and worth consulting, regardless of their age and a certain tendency to overemphasize Epictetus' philosophical orthodoxy. Long's immensely learned study is the first comprehensive survey after Bonhöffer. 
Some things are under our control, while others are not under our control. Under our control are conception, choice, desire, aversion, and, in a word, everything that is our own doing; not under our control are our body, our property, reputation, office, and, in a word, everything that is not our own doing.

Ench. 1.1; trans. Oldfather, LCL

Epictetus uses several names for the things which are not our own and not under our control. They are, for example, external things ( $\tau \dot{\alpha} \dot{\varepsilon} x \tau \dot{\delta} \varsigma$ ) or materials ( $\hat{\lambda} \lambda \alpha$ ) (Disc. 1.29.2). According to Epictetus, material things are indifferent ( $\alpha i$

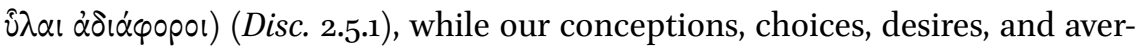
sions are not. These mental operations follow our value judgements ( $\delta \delta \gamma \mu \alpha \tau \alpha)$ on external things. According to Epictetus, all external things are indifferent as such. It is our judgements that make them good or bad. In other words, that which is good or bad lies not in external things as such but solely in our judgements of them. This is his Stoic theory of value. Embracing this theory has an effect on one's mental state. As external things are indifferent, they cannot disturb us. "What, then, are the things that weigh upon us and drive us out of our senses? Why, what else but our judgements" (Disc. 2.16.24; trans. Oldfather, LCL). For example, a tyrant can imprison, behead, or exile anyone, but those who have embraced philosophy can remain undisturbed in spite of all these tyrannical operations. Tyrants threaten only external things. One can remain

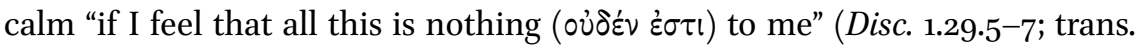
Oldfather, LCL).

On the other hand, one can ask if this theory of value makes one totally negligent in one's responsibilities and even one's own life. Why did Epictetus continue to live, eat, and teach in his school in spite of the fact that these all constitute indifferent external things? In his answer, Epictetus emphasizes that the indifference to external things does not determine the use of those things: "Materials are indifferent, but the use of which we make of them is not

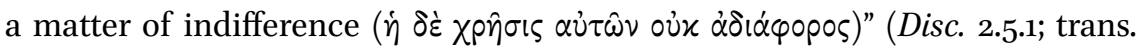
Oldfather, LCL). In Discourses 2.16, Epictetus presents the right use of external things as the law of God. The starting point is the fundamental division between the things which are our own and which are not.

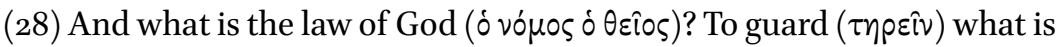

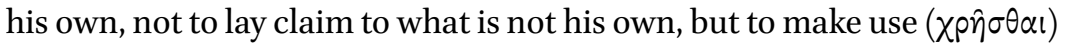
of what is given to him, and not to yearn for what has not been given; when something is taken away, to give it up readily and without delay,

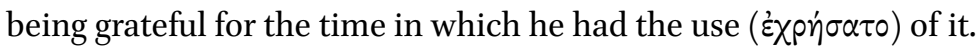

Disc. 2.16.28; trans. Oldfather, LCL 
Now I approach our theme more directly. Keeping an eye on Paul, one can see here a certain terminological similarity. According to Epictetus, people should guard ( People should be content with the things which God has loaned us, make use $\left(\chi p \hat{\eta} \sigma \theta_{\alpha}\right)$ of them, and give them away if it is God's will (cf. Disc. 2.5.22; Ench. 11). This attitude also concerns social positions. They belong to the external things of which people should make use. In the same text, Epictetus presents this attitude in an exemplary prayer: "Wouldst Thou have me to hold office, or remain in private life; to remain here or go into exile; to be poor or be rich? I will defend all these Thy acts before men" (Disc. 2.16.42). It does not matter what the social position is. Slaves and masters are brothers under God (Disc. 1.13). What makes a difference is the careful use of the position which God has provided.

A similar attitude toward social positions is found in Discourses 3.24, where Epictetus also speaks of God's commands. Epictetus says that a good and excellent man fills his place ( $\chi \omega \dot{\omega} \alpha)$ "with due obedience to God" until it is time to depart (Disc. 3.24.95-97; trans. Oldfather, LCL).

(98) "How do you depart?" "Again ( $\pi \dot{\alpha} \lambda \iota v)$, as Thou didst wish it, as a free

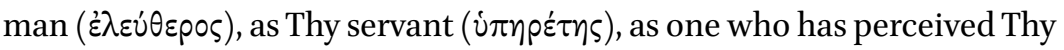

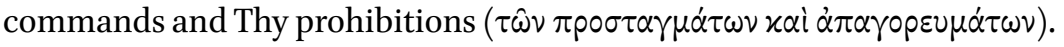
(99) But so long as I continue to live in Thy service, what manner of man wouldst Thou have me be? An official or a private citizen, a senator or one of the common people, a soldier or a general, a teacher or a head of

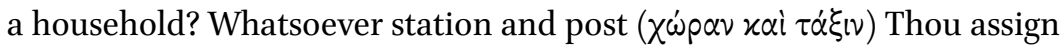
me, I will die ten thousand times, as Socrates says, or ever I abandon it."275

Disc. 3.24.98-99; trans. Oldfather, LCL

Epictetus says that one should depart from life in accordance with God's "commands and prohibitions," which is a Stoic definition of law. ${ }^{276}$ The word 'again' indicates that God's law regulates not only dying but also life. Obedience to God's law must happen freely. One should serve God as a free man or as a

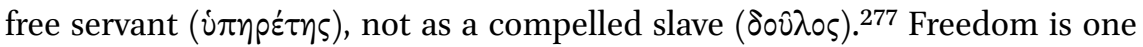
of Epictetus' main themes, and it recurs in the pages of Discourses time and again. ${ }^{278}$ I add just one further example: "I am a free man and a friend of God, so as to obey Him of my own free will. No other thing ought I to claim, not body,

275 This may be a paraphrasing of Plato, Apol. 28e-29a (cf. Disc. 1.9.23-24; 3.1.19-20).

276 Bonhöffer 1911, 231; SVF 3.314.

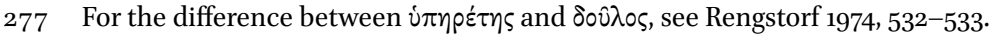

278 Epictetus' emphasis on freedom can be illustrated by the fact that the longest discourse (Disc. 4.1) deals with this theme. Willms (2011) has recently written an in-depth commentary on this discourse and provides secondary literature. 
or property, or office, or reputation ... I cannot transgress any of His commands

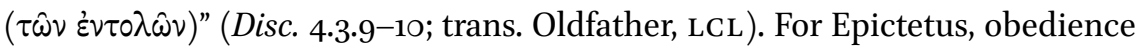
to God's law brings freedom. ${ }^{279}$ Later in Discourses 3.24, Epictetus explains that one is a witness in service to God, showing that social positions are indifferent, while obedience to God's commands is everything:

He is training me, and making use of me as a witness to the rest of men

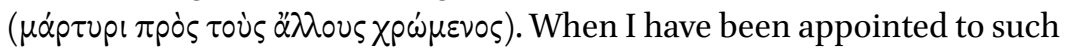
a service, am I any longer to take thought as to where I am, or with whom, or what men say about me? Am I not wholly intent upon God, and His

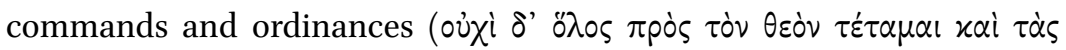

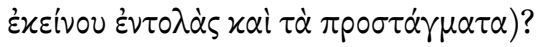

Disc. 3.24.114; trans. Oldfather, LCL

Remembering 1 Corinthians 7 , it is worth adding that an exemplary person is "a

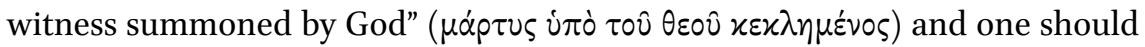

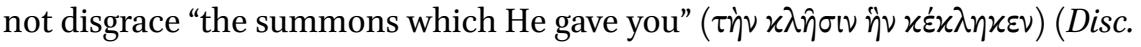
1.29.46, 49; trans. Oldfather, LCL). One should face difficulties "with trust in Him who has called you to face them and deemed you worthy of this position"

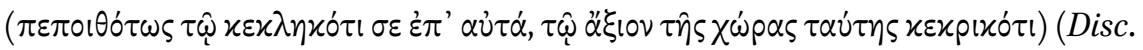
2.1.39; trans. Oldfather, LCL).

Before revisiting what Paul might have meant with "the commandments of God" (1 Cor. 7:19), I briefly summarize previous findings on Epictetus' thought. First, the external things like social positions are adiaphora, but their use is not. Actually, God has decreed different kinds of external things for different people. This decreeing Epictetus calls divine law, using such Greek terms as

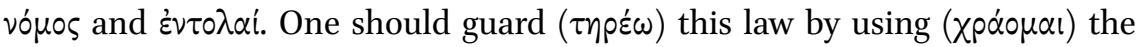
external things. The social position can be understood not only as a divine law but also God's call ( $\varkappa \alpha \lambda \varepsilon \dot{\varepsilon} \omega, \chi \lambda \hat{\eta} \sigma \varsigma)$. I claim that Epictetus' thoughts shed light on what Paul meant with "the commandments of God." If Paul means the commandments of the Torah, his idea is totally blurred, as evidenced by the indifference toward circumcision. And being so blurred, it does not explain what the content of the "commandments" might be. In this context, Paul does not speak of the Torah but of social positions.

In 1 Cor. 7:17-24, Paul stresses that God calls ( $\varkappa \alpha \lambda \varepsilon \dot{\varepsilon} \omega, \chi \lambda \hat{\eta} \sigma \iota \zeta)$ each person within his or her social position, not beyond or outside it. The position is thus

279 Gretenkord 1981, 217-218. Gretenkord juxtaposes this against what Paul states, but actually Gretenkord is discussing with Bultmann's interpretation of Paul. The new perspective on Paul may see the relationship as less oppositional. The covenantal nomism projected onto Paul and Judaism, however, may also fit with Greco-Roman religion (Roitto 2013). 
indifferent. This is immediately clear when Paul says that circumcision and uncircumcision are nothing. The indifference of status seems to also be the background when he states that a slave should not be concerned about his or her status. In this regard, any concern with status seems to be out of place since statuses are indifferent. Paul qualifies the positions by saying that slaves are freedmen of the Lord, while free persons are the Lord's slaves. Then, he immediately continues by calling all Christians slaves bought by the Lord. ${ }^{280}$ This change of viewpoints illustrates the relativity of social positions: anyone can be called free or slave. Thus, the external social positions are nothing that one should concern oneself with. This view is just a variation of Epictetus' logic when he says that one can remain calm when losing everything, because those

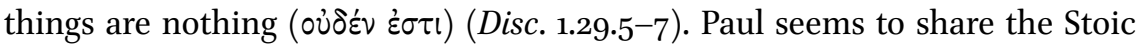
theory of value: external things are indifferent and therefore do not have an effect on our inner selves.

Paul strongly stresses that Christians should remain in their social positions. If social positions are indifferent, why should anyone foster, attend to, or take care of them? Epictetus' philosophy makes this paradox understandable: external things are indifferent, but their use ( $\chi p \hat{\eta} \sigma \iota \varsigma)$ is not. Paul even uses the Stoic technical verb $\chi p \alpha \dot{\alpha} 0 \mu \alpha \mathrm{l}$ in verse 21. This idea has both Paul and Epictetus generally emphasizing that one should remain in one's position. Paul possibly speaks of changing social status in verse 1 of Cor 7:21. This verse is linguistically unclear: what is the object of the verb $\chi p \alpha$ ó $\mu \alpha$ ? Should the slave continue to make use of her or his position as a slave or use the opportunity to become free? Both interpretations can be understood along the lines of Stoic philosophy.

The choice between freedom and slavery was officially in the hands of the owner, not in the hands of the slave. ${ }^{281}$ If Paul admonishes one to remain in slavery, he means that slaves should not make any unofficial petitions to their owners for this freedom. Such a petition would express a striving for an external social position, and this is something that Stoics do not accept. According to the Stoics, social freedom is indifferent and, therefore, it is not worth striving for. Still, if the owner just asks what the slave would like to happen, there is no striving; Stoics would surely advise the slave to gain his or her freedom. ${ }^{282}$ Thus, both interpretations of 1 Cor. 7:21 can (but must not) be read along the lines of Stoic philosophy. The Stoic reading is very probable, since Paul stands close to the Stoic theory of value and Stoic admonitions to remain in one's social

280 The Greek verb $\alpha$ $\gamma 0 p \alpha \dot{\zeta} \omega \omega$ denotes the buying of a slave for service, not making a payment for freedom (Jones 1987, 31; Martin 199o, 63). Cf. 1 Cor. 6:19-20.

281 Bartchy 1973, 106-109. Bartchy himself tries to interpret the verse in a third way, that Paul is admonishing manumitted slaves to remain Christians.

282 Bonhöffer 1911, 170-172. Linguistically I prefer the first interpretative option: the slave should remain in slavery. See Huttunen 20o9, 28-29. 
position. Moreover, there is the Stoic technical verb $\chi_{p} \alpha \dot{\alpha} 0 \mu \alpha \mathrm{l}$ in the verse. In the last analysis, it is quite unimportant whether or not Paul admonishes slaves to make use of the opportunity to become free or continue to make use of their position as a slave. What is decisive here is that Paul is probably presenting the Stoic idea that one should make use of indifferent things - whatever they are.

All this Stoic philosophy of life can be viewed in theological terms. Epictetus utters prayers to express his fealty in any social position that God decrees. Whatever the position is, Epictetus promises to remain in it, because God prefers such conduct. Epictetus says that God summons or calls ( $\varkappa \alpha \lambda \varepsilon^{\prime} \omega, x \lambda \hat{\eta} \sigma \iota \varsigma$ ) people to be his witness. The idea of the divine calling is also central in Paul's passage. The idea differs only slightly from that of Epictetus. For Paul, God's call has a double meaning: it is at the same time a call to remain in a social position and to also become a Christian. ${ }^{283}$ For Epictetus, the connection between the call and the social position is vaguer. He says that God calls people to be his witness. Although Epictetus does not explicitly say that God calls us to a certain social position, it is clear that the positions are given by God. The philosophical differences between Paul and Epictetus are minor, and they do not diminish the general philosophical similarity.

God's call is a Stoic idea and Paul seems to adjust it in the context of a Stoic theory of value. The distinct Stoic coloring in the passage leads to a Stoic explanation for the commandments of God in 1 Corinthians 7:19. Here again occurs a term with a Stoic ring. The word $\tau \dot{p} p \eta \sigma \varsigma$ is suggestive of $\tau \eta \rho \varepsilon ́ \omega$, which Epictetus uses in the context of a divine law (Disc. 2.16.28). The divine law stresses the importance of the Stoic theory of value and admonishes one to make use $(\chi p \dot{\alpha} \sigma \mu \alpha \mathrm{l})$ of any external thing that God has given. Epictetus also speaks of God's commandments ( $\dot{\varepsilon} v \tau 0 \lambda \alpha i$ ), and he uses other similar expressions when speaking of social positions. This theological parlance serves to instruct the Stoic theory of value. This theory is present in 1 Corinthians 7:17-24 with several other Stoic features. In this context, the commandments of God are easily interpreted in a manner that is similar to that in Epictetus: the commandments refer to the different social positions. Each position imposes differing demands, which explains the plural form.

This Stoic interpretation of the commandments makes excellent sense in the context of 1 Corinthians 7:17-24. It is much more difficult to interpret the relevant commandments in relation to either the love command or the Mosaic commandments in general. The context does not speak in favor of love or the Torah. However, Paul can sometimes blur the line between the Stoic natural law and the Torah, as exemplified in Romans 2:14. It would be unwise, therefore, to totally exclude the possibility that Paul may have had the commandments of

283 Plank 1987, 26; Schrage 1995, 137. 
the Torah in mind. If he can blur the line between philosophy and the Torah in Romans 2, why could it not happen here? Be that as it may, the actual content of the commandments is a version of Stoic philosophy. If Paul had the Torah in mind, he must have thought of it in strongly philosophical terms. In this sense, the Torah and philosophy do not exclude each other.

After noting the strong Stoic flavor in 1 Corinthians 7:17-24, one clear difference between Paul and Epictetus should be added. For Paul, only Christ relativizes the indifference of social positions. He speaks of an equality between Christians within different statuses and of no equality between all people, as Epictetus has it. One can safely assume that at this point Paul differed from all Stoics - or at least from non-Christian Stoics. Paul's thought in this passage has such a clear Stoic character that it is a matter of preference if one chooses to call it Stoicism or not. Probably Christian Stoicism is a more apt characterization. Moreover, Paul's Jewish heritage does not exclude philosophical elements in his thought. We can find similar features in Paul's other epistles as well. Romans 1 presents a gentile lapse as a shift from the aniconic monotheism to a polytheistic image cult, which can be understood in both Jewish and philosophical terms. ${ }^{284}$ Romans 7 presents the problem of the Torah as a soliloquy of a divided self. This divided self is a topos in the philosophical literature. ${ }^{285}$

In this section, I have gone through a sample of the earliest remaining Christian texts that exhibit philosophical elements. One can safely assume that there has been an interaction between Jerusalem and Athens from the beginnings of Christianity, despite what Tertullian may have claimed. The use of philosophy by Christians was not a later innovation and the recognition from the side of non-Christian philosophers was based on the actual reality of the early Christians. The early Christians presented philosophical elements, as is evident in Paul's texts. It can still be discussed if Paul already sought philosophical recognition, but the picture that Acts presents of Athens programmatically shows him as a new Socrates among the philosophers, thereby making a claim that Christianity should be seen as a philosophy. Acts reflects what became mainstream in the following centuries.

\subsection{Mutual Recognition Becomes Mainstream}

About one hundred years after Paul, the Christian apologist Justin Martyr wrote about his conversion to Christianity. After vainly seeking the truth in

284 Van Kooten 2008, 343-356; Huttunen 2009, 37-62.

285 Wasserman (2008) has proposed that Paul's background is Platonic philosophy, while I prefer to see Paul's words as a variation of the Stoic version of the inner conflict (Huttunen 2009, 101-126). 
numerous philosophical schools, one day he encountered a mysterious old man on a lonely shore. The characterization of the old man hints at the figure of Socrates and, in a sense, Socrates becomes the midwife of Justin's conversion. ${ }^{286}$ The man tells him about Christianity and then leaves, but not without making a lasting impression:

I have not seen him since. But straightway a flame was kindled in my soul; and a love of the prophets, and of those men who are friends of Christ, possessed me; and whilst revolving his words in my mind, I found this philosophy alone to be safe and profitable. Thus, and for this reason, I am a philosopher.

Dial. 8; trans. ANF 1.198

Justin's conversion to Christianity was no abrupt shift from philosophy to religion. As Runar Thorsteinsson notes: "Justin's new identity as a Christian philosopher became readily integrated with his identity as a Platonist." ${ }^{287}$ His recognition of philosophy becomes clear when he assesses it quite positively. Christianity, the true philosophy, was fragmentarily present already in the ancient tradition: "There seem to be seeds of truth among all men; but they are charged with not accurately understanding [the truth] when they assert contradictories" (1 Apol. 44; trans. ANF 1.177). As there were excellent preChristian philosophers, Justin reasons that they must have been Christians, since they stuck to reason, which he identifies with Christ (cf. John 1:1-3): "He [Christ] is the Word ( $\lambda$ ó $^{\circ} \mathrm{v}$ ö $v \tau \alpha$ ) of whom every race of men were partakers; and those who lived reasonably ( $\mu \varepsilon \tau \dot{\alpha} \lambda{ }^{\circ}$ 'rov) are Christians, even though they have been thought atheists; as, among the Greeks, Socrates and Heraclitus, and men like them" (Justin Martyr, 1 Apol. 46; trans. ANF 1.178). Justin in a way Christianizes the Greek intellectual tradition by saying that Christianity does not contradict but completes it. This apologetic strategy to seek recognition in the Greco-Roman intellectual milieu continued after Justin. ${ }^{288}$

The standard picture is that Paul's, Justin's, and other Christians' bold claims of Christianity as the supreme philosophy were received with disgust. ${ }^{289}$ Three famous accounts of Christians are quoted time and again: those of Tacitus (Ann. 15.44.2-5), Suetonius (Nero 16), and Pliny the Younger (Ep. 10.96), according to which Christianity is a criminal superstition. However, this is only a partial

\footnotetext{
286 Thorsteinsson 2012, 496, 5 O2.

287 Thorsteinsson 2012, 509; see Klostergaard Petersen 2017a, 11-12: "Justin did not conceive of Christianity as something so different from philosophy that it would preclude a description of Christianity in terms of philosophy."

288 Hadot 2002, 239-240.

289 See, e.g., Cook 2010, 2.
} 
truth, as I argued in the previous section. The Stoic Epictetus, the Emperor Marcus Aurelius, the satirist Lucian, and Galen described Christians more or less positively. The chief indicator of recognition is the fact that Christians are assessed in the category of philosophers-albeit with certain failures. The most positive is Galen, who explicitly mentions "the school of Moses and

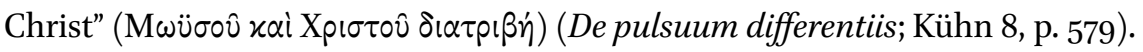
Although Christians belong to the people who are unable to follow demonstrative arguments, they have attained virtue "not inferior to that of genuine philosophers."

It would require a more profound analysis to position early Christianity on the intellectual map of the ancient philosophical schools. However, none of the texts (Colossians 2, Acts 17, 1 Corinthians 1-2) present a blatant misrecognition of philosophy in the manner of Tertullian's Jerusalem/Athens opposition. Actually, there are clearly philosophical elements in them, just as in other texts, which do not overtly discuss philosophy. I presented 1 Corinthians 7 , which clearly utilizes Stoic philosophy as a natural part of argumentation. Justin proves that by the mid-2nd century at the latest, a Christian could recognize himself as a philosopher. But this development must have begun also earlier. The Epistle to the Colossians attests that around the year $100 \mathrm{CE}$, some Christians called their religious conviction "philosophy." Around the same time, Luke "Socratized" Paul, and in the early and century, Epictetus included the Christians in the category of philosophy, in spite of whatever deficiencies Christianity had from his Stoic point of view.

Early Christians recognized ancient philosophy as a legitimate part of their faith and searched for recognition in that intellectual milieu. The relationship was not equal, however, as Christianity was a novelty in Greco-Roman culture. Some pagan authors attest to being disgusted by Christianity. But this is not the whole picture. From the early and century onwards, we also have information of pagans granting recognition to Christians. This was the strengthening development that led finally to the Christianization of the whole Greco-Roman intellectual world in the following centuries. The popular tradition that separates philosophy from religion does not recognize this strong and-I would say-mainstream course of Western intellectual history. The separation is more of an ideological attempt either to secure a non-human and divine status for Christianity or to dismiss Christianity as non-intellectual nonsense. Responsible scholarly work must transcend ideological biases. If the ancient situation has any significance for modern discussions, it will show that mutual misrecognition is not the only possibility. Non-Christian philosophers and Christians recognized each other at least partially. 